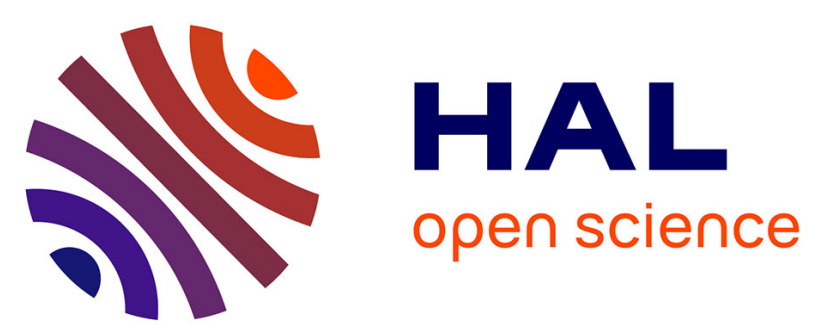

\title{
Deleting a Chromatin Remodeling Gene Increases the Diversity of Secondary Metabolites Produced by Colletotrichum higginsianum
}

Jean-Felix Dallery, Géraldine Le Goff, Emilie Adelin, Bogdan Iorga, Sandrine Pigné, Richard O'connell, Jamal Ouazzani

\section{To cite this version:}

Jean-Felix Dallery, Géraldine Le Goff, Emilie Adelin, Bogdan Iorga, Sandrine Pigné, et al.. Deleting a Chromatin Remodeling Gene Increases the Diversity of Secondary Metabolites Produced by Colletotrichum higginsianum. Journal of Natural Products, 2019, 82 (4), pp.813-822. 10.1021/acs.jnatprod.8b00796 . hal-02346243

\section{HAL Id: hal-02346243 \\ https://hal.science/hal-02346243}

Submitted on 10 Mar 2021

HAL is a multi-disciplinary open access archive for the deposit and dissemination of scientific research documents, whether they are published or not. The documents may come from teaching and research institutions in France or abroad, or from public or private research centers.
L'archive ouverte pluridisciplinaire HAL, est destinée au dépôt et à la diffusion de documents scientifiques de niveau recherche, publiés ou non, émanant des établissements d'enseignement et de recherche français ou étrangers, des laboratoires publics ou privés. 


\section{Deleting a Chromatin Remodeling Gene Increases the Diversity of Secondary}

\section{Metabolites Produced by Colletotrichum higginsianum}

Jean-Félix Dallery, ${ }^{\dagger}$ Géraldine Le Goff, ${ }^{\dagger}$ Emilie Adelin, ${ }^{\dagger}$ Bogdan I. Iorga, ${ }^{\dagger}$ Sandrine Pigné,,

Richard J. O'Connell, ${ }^{\ddagger}$ Jamal Ouazzani ${ }^{\star *}$

${ }^{\dagger}$ Centre National de la Recherche Scientifique, Institut de Chimie des Substances Naturelles ICSN, Avenue de la Terrasse 91198, Gif-sur-Yvette, cedex, France.

¥ UMR BIOGER, INRA, AgroParisTech, Université Paris-Saclay, Avenue Lucien Brétignières, 78850, Thiverval-Grignon, France. 
Colletotrichum higginsianum is the causal agent of crucifer anthracnose disease, responsible for important economic losses in Brassica crops. A mutant lacking the CclA subunit of the COMPASS complex was expected to undergo chromatin decondensation and the activation of cryptic secondary metabolite biosynthetic gene clusters. Liquid-state fermentation of the $\triangle \mathrm{ccl} A$ mutant coupled with in situ solid-phase extraction (LSF-SPE) led to the production of three families of compounds, namely colletorin and colletochlorin derivatives with two new representatives colletorin D (1) and colletorin D acid (2), the diterpenoid $\alpha$-pyrone higginsianin family with two new analogs higginsianin C (3) and 13-epi-higginsianin C (4) and sclerosporide (5) coupling a sclerosporin moiety with dimethoxy inositol. 
The ascomycete fungus Colletotrichum higginsianum, causal agent of crucifer anthracnose disease, is responsible for important economic losses on cultivated members of the Brassicaceae in tropical and sub-tropical regions but also infects the model plant Arabidopsis thaliana. ${ }^{1,2}$ Recently, the genome of this fungus was re-sequenced using long-read sequencing technology (PacBio SMRT) producing a gapless assembly of the 12 chromosomes. ${ }^{3}$ This new version of the genome has facilitated a more accurate annotation of secondary metabolism (SM) genes, which revealed that that the $C$. higginsianum SM gene repertoire is one of the largest described to date, ${ }^{4}$ comprising 89 predicted SM Key Genes (SMKG) and 77 clusters. ${ }^{3}$ Transcriptome sequencing showed that of the 23 SM gene clusters expressed under any of the four tested conditions, the majority (21) were only induced during plant infection and the patterns of expression were highly stage-specific. ${ }^{3}$ Deleting genes coding chromatin-remodeling proteins has proven to be a successful approach to unlock cryptic secondary metabolism pathways in several genera of filamentous fungi. . $^{5-8}$ The COMPASS ( $\underline{\mathrm{COM}}$ plex of $\underline{\text { Proteins }} \underline{\mathrm{AS}}$ sociated with $\underline{\mathrm{S}} \mathrm{et} 1)$ is conserved from yeast to multicellular eukaryotes and consists of eight proteins that collectively mediate the mono-, di- and trimethylation of lysine 4 in histone H3. ${ }^{9}$ In two Aspergilli (A. nidulans and A. fumigatus), the deletion of the gene encoding one COMPASS subunit called CclA resulted in the overproduction of at least 12 secondary metabolites, of which nine were identified and linked to corresponding SM gene clusters. ${ }^{5,10}$ Deletion of a $c c l A$ homolog in Pestalotiopsis fici led to the discovery of pestaloficiols $\mathrm{T}$ to $\mathrm{V}$ and ficipyrone $\mathrm{C} .{ }^{8}$

In an effort to activate cryptic SM biosynthetic pathways in C. higginsianum, we deleted an orthologue of the $c c l A$ gene in this fungus. Phenotypic characterization of the resulting mutant and complemented strain is reported elsewhere (Dallery et al., submitted). A key finding from comparative metabolite profiling with HPLC-MS was that several compounds are over-produced by the $\Delta c c l A$ mutant relative to the wild-type strain. While some of these were already reported from C. nicotianae ${ }^{11-13}$ and more recently $C$. higginsianum, ${ }^{14,15}$ an additional five new compounds were also detected. Here, we report the characterization of these new molecules that belong to three 
different families: two new colletorin and colletochlorin derivatives, namely colletorin D (1) and colletorin D acid (2), two new representatives of the higginsianin family, namely higginsianin C (3) and 13-epi-higginsianin C (4), and sclerosporide (5), a novel conjugate of the sesquiterpene sclerosporin and dimethoxy inositol. 
The $C$. higginsianum mutant $\Delta c c l A$ mutant was obtained by targeted gene deletion. The mutant and the wild type (C. higginsianum IMI 349063) were grown identically in potato dextrose broth (PDB) with in-situ solid-phase extraction (SPE) on Amberlite XAD-16 resin beads. ${ }^{16,17}$ After five days of growth at $25{ }^{\circ} \mathrm{C}$ and $150 \mathrm{rpm}$, the medium was removed by filtration. The recovered resin was washed extensively with $\mathrm{H}_{2} \mathrm{O}$ and the trapped compounds desorbed with EtoAc, purified by a combination of flash chromatography and preparative HPLC and identified by 1D, 2D-NMR and mass spectrometry.

The comparison of the HPLC-ELSD chromatograms of the $\triangle c c l A$ and the wild type extracts shows that the mutant over produces compounds that were either not detectable or produced in only small amounts by the wild type (Figure 1).

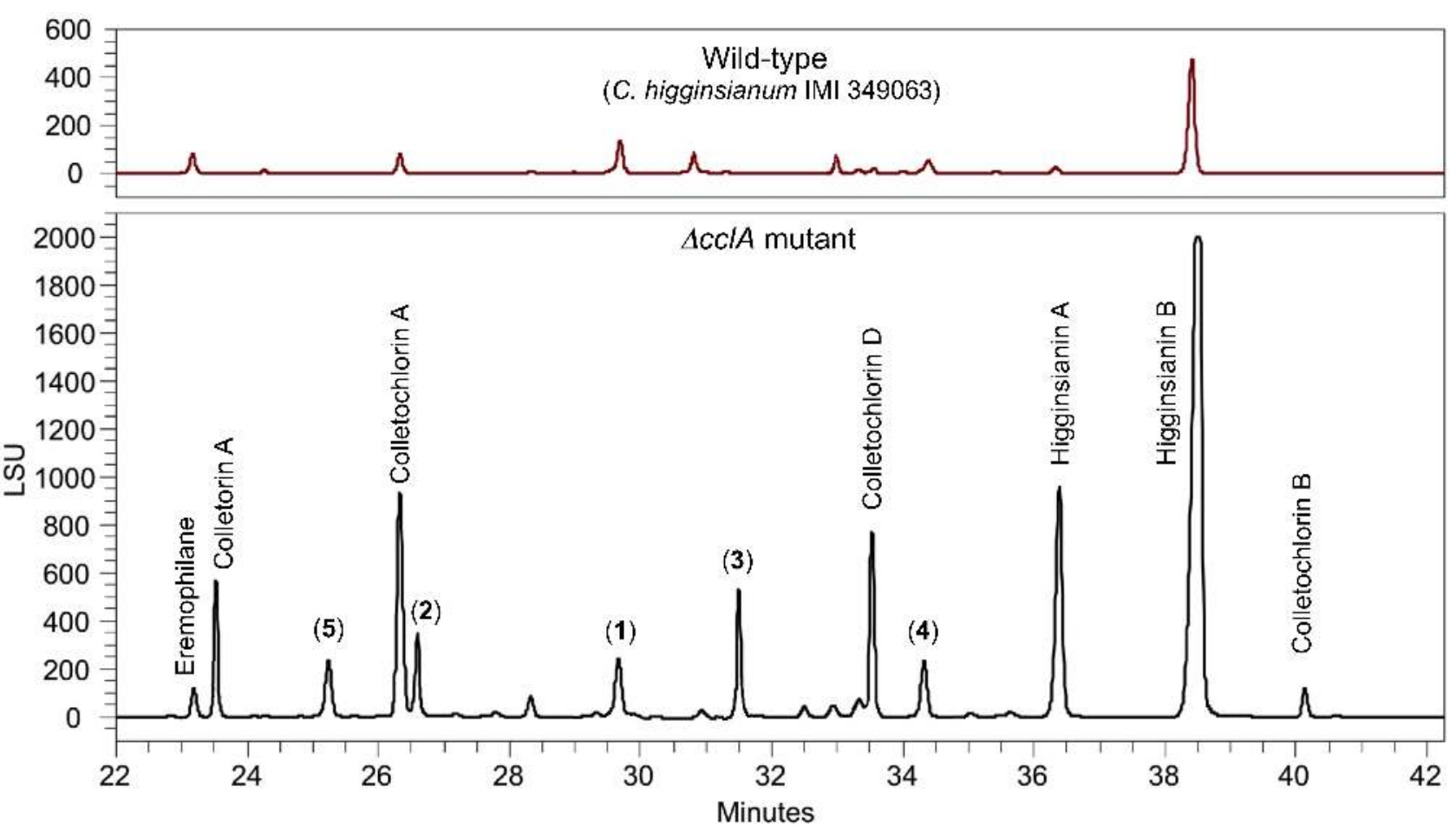

Figure 1. HPLC-ELSD comparison of the raw extracts obtained from the wild-type strain (C. higginsianum IMI 349063) and $\triangle c c l A$ mutant (LSU = light scattering units).

The first group of compounds belongs to the colletorin/colletochlorin family. ${ }^{11,12,15,18-20}$ Among the four sub-groups A-D, only the $\mathrm{C}$ sub-group was not detected in the $\Delta c c l A$ mutant while only colletochlorin A (7) was detected in the wild type. Compounds $\mathbf{1}$ and $\mathbf{2}$ are reported here for the first time. Their ${ }^{1} \mathrm{H}$ and ${ }^{13} \mathrm{C}$ NMR data are shown in Table 1. 


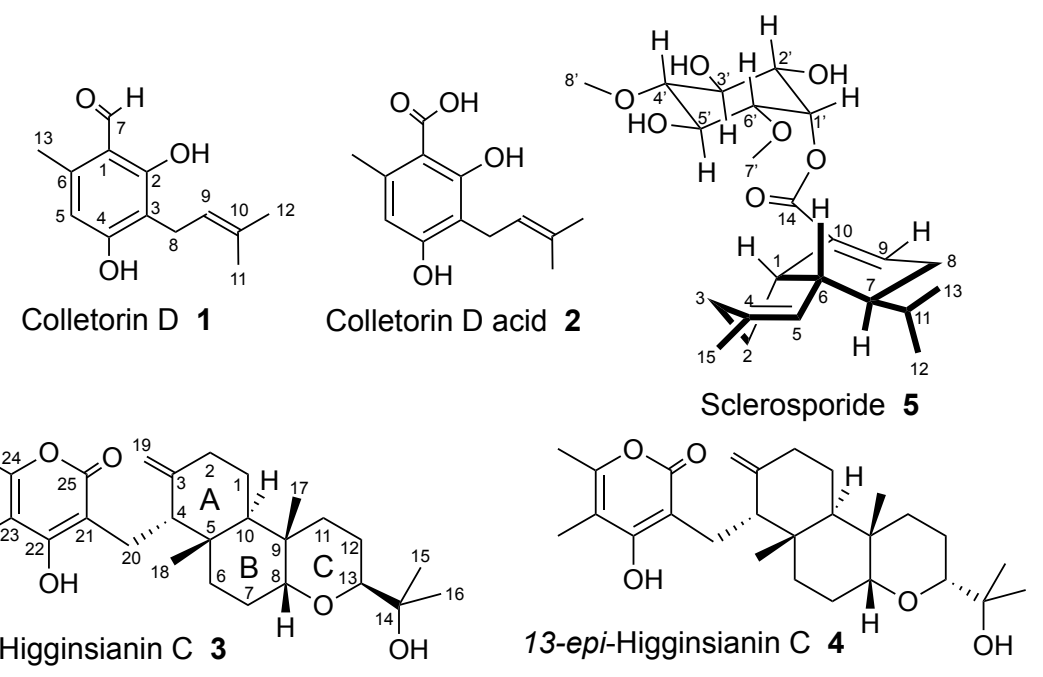

Table 1. NMR Data of Compounds 1 and 2 and Comparison with Colletochlorin D (9).

\begin{tabular}{|c|c|c|c|c|c|c|}
\hline \multirow[b]{2}{*}{$\mathrm{N}^{\circ}$} & \multicolumn{2}{|c|}{ Colletochlorin D $9\left(500 \mathrm{MHz}, \mathrm{CDCl}_{3}\right)$} & \multicolumn{2}{|c|}{ Compound $1\left(500 \mathrm{MHz}, \mathrm{CDCl}_{3}\right)$} & \multicolumn{2}{|c|}{ Compound 2 (500 MHz, CD $\left.\mathrm{CD}_{3} \mathrm{OD}\right)$} \\
\hline & $\delta_{\mathrm{C}}$, type & $\delta_{\mathrm{H}}$ mult, $(J$ in $\mathrm{Hz})$ & $\delta_{\mathrm{C}}$, type & $\delta_{\mathrm{H}}$ mult, $(J$ in $\mathrm{Hz})$ & $\delta_{\mathrm{C}}$, type & $\delta_{\mathrm{H}}$ mult, $(J$ in $\mathrm{Hz})$ \\
\hline 1 & $113.5, \mathrm{C}$ & - & 113.1, C & - & 104.1, C & - \\
\hline $2-\mathrm{OH}$ & & $6.43, \mathrm{~s}$ & & $6.23, \mathrm{~s}$ & & - \\
\hline 2 & $162.5, \mathrm{C}$ & - & $164.0, \mathrm{C}$ & - & $163.3, \mathrm{C}$ & - \\
\hline $4-\mathrm{OH}$ & & $12.69, \mathrm{~s}$ & & $12.69, \mathrm{~s}$ & & - \\
\hline 3 & $114.8, \mathrm{C}$ & - & $111.5, \mathrm{C}$ & - & 112.6, C & - \\
\hline 4 & $156.6, \mathrm{C}$ & - & $162.7, \mathrm{C}$ & - & $159.6, \mathrm{C}$ & - \\
\hline 5 & $114.7, \mathrm{C}$ & - & $110.8, \mathrm{CH}$ & $6.15, \mathrm{~s}$ & $110.3, \mathrm{CH}$ & $6.15, \mathrm{~s}$ \\
\hline 6 & $137.9, \mathrm{C}$ & - & $142.4, \mathrm{C}$ & - & $140.8, \mathrm{C}$ & - \\
\hline 7 & 193.6, CH & $10.14, \mathrm{~s}$ & 193.3, CH & $10.10, \mathrm{~s}$ & $170.9, \mathrm{C}$ & - \\
\hline 8 & $22.2, \mathrm{CH}_{2}$ & $3.40, \mathrm{~d}(7.2)$ & 21.6, $\mathrm{CH}_{2}$ & $3.40, \mathrm{~d}(7.2)$ & $21.4, \mathrm{CH}_{2}$ & $3,22 \mathrm{~d}(7.2)$ \\
\hline 9 & 121.2, CH & $5.25, \mathrm{t}(6.9)$ & $121.3, \mathrm{CH}$ & $5.27, \mathrm{t}(7.2)$ & $122.9, \mathrm{CH}$ & $5.17, \mathrm{t}(7.2)$ \\
\hline 10 & $133.8, \mathrm{C}$ & - & $136.4, \mathrm{C}$ & - & $130.0, \mathrm{C}$ & - \\
\hline 11 & $26.1, \mathrm{CH}_{3}$ & $1.80, \mathrm{~s}$ & $26.1, \mathrm{CH}_{3}$ & $1.84, \mathrm{~s}$ & $24.7, \mathrm{CH}_{3}$ & $1.72, \mathrm{~s}$ \\
\hline 12 & $17.9, \mathrm{CH}_{3}$ & $1.71, \mathrm{~s}$ & $18.3, \mathrm{CH}_{3}$ & $1.78, \mathrm{~s}$ & $16.8, \mathrm{CH}_{3}$ & $1.61, \mathrm{~s}$ \\
\hline 13 & $14.7, \mathrm{CH}_{3}$ & $2.60, \mathrm{~s}$ & $18.2, \mathrm{CH}_{3}$ & $2.51, \mathrm{~s}$ & $23.0, \mathrm{CH}_{3}$ & $2.42, \mathrm{~s}$ \\
\hline
\end{tabular}

NMR data for $\mathbf{1}$ are similar to those of the colletochlorin D (9), except for the presence of a proton at position 5 in $\mathbf{1}$. Based on the molecular formula deduced from the HRESIMS, $\mathbf{1}$ is the dechlorinated form of $\mathbf{9}$ and was named colletorin D. The main difference between $\mathbf{1}$ and $\mathbf{2}$ is the shift in C-7 from the aldehyde position at $\delta_{\mathrm{C}} 193.3$ to a carboxyl position at $\delta_{\mathrm{C}} 170.9$, which is supported by the molecular formula deduced from the HRESIMS. Compound $\mathbf{2}$ was named colletorin D acid.

Based on the structures of the known colletorin/colletochlorin compounds produced by Colletotrichum and the new metabolites highlighted in this study, a plausible pathway for the biosynthesis of all members of this family is presented in Figure 2. The precursors are orsellinic acid for 5-chloro derivatives and orcinol for 1-chloro derivatives through a chloroorcinol 
intermediate. All of these compounds were previously reported as Colletotrichum metabolites. ${ }^{15,19,21}$ Except for colletochlorin $\mathrm{H}$ in which the tetrahydropyran ring closure seems unusual, all of the reactions reported in Figure 2 are very common in fungal secondary metabolite biosynthetic pathways and the genes encoding these enzymes are distributed in different Colletotrichum clusters. $^{3}$

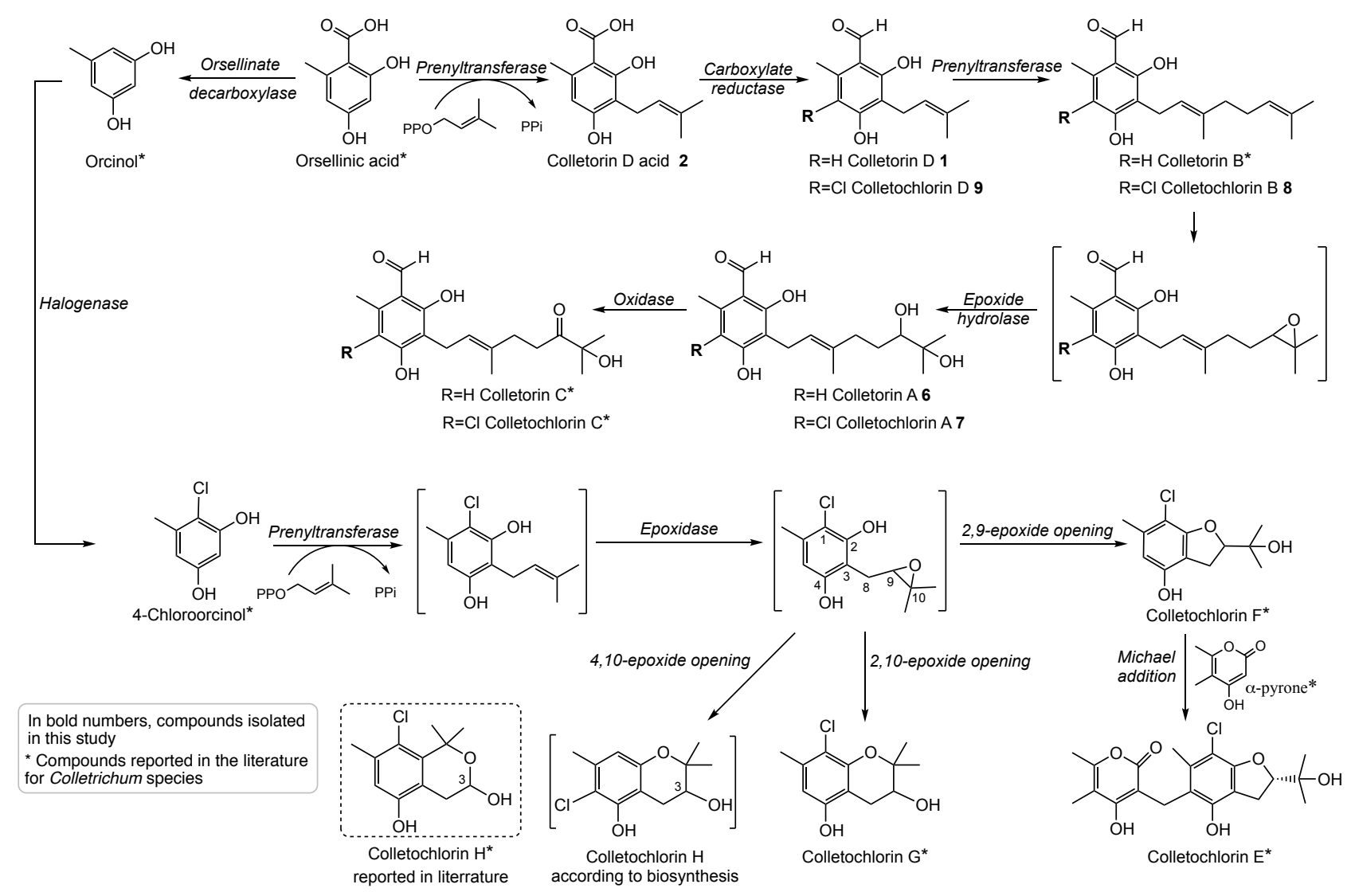

Figure 2. Proposed biosynthetic pathway of the colletorin/colletochlorin family (Although the colletochlorin $\mathrm{H}$ structure reported by Masi et $a .^{20}$ is supported by specific NMR data (shift of proton 3-H), the fact remains that this structure does not fit with the biosynthetic scheme and may perhaps require reexamination).

Besides the colletorin/colletochlorin family, related compounds carrying the 5-chloro-2,4dihydroxy-6-methylbenzaldehyde moiety were previously isolated from other fungal strains e.g. ascochlorin, ${ }^{22-24}$ cylindrols, ${ }^{25}$ ascofuranone, ${ }^{26}$ and illicolins. ${ }^{27}$

The second group of metabolites produced by the $\Delta c c l A$ mutant consisted of two new higginsianins 3 and 4 isolated together with higginsianin A (10). These compounds are not detected in the wild type extract. Compound 3 was obtained as a white powder. Its molecular formula, $\mathrm{C}_{27} \mathrm{H}_{40} \mathrm{O}_{5}$, was 
deduced by HRESIMS with $m / z$ 445.2974 $[\mathrm{M}+\mathrm{H}]^{+}$. This formula was corroborated by the ${ }^{13} \mathrm{C}$ NMR spectrum and revealed eight degrees of unsaturation. Based on the following spectroscopic data, these degrees of unsaturation were attributed to the $\alpha$-pyrone moiety, the methylidene group and three six-membered rings. The ${ }^{13} \mathrm{C}$ NMR spectrum revealed the presence of 27 carbons, attributed by ${ }^{1} \mathrm{H}^{13}{ }^{13} \mathrm{C}$ EDT-HSQC to six methyl carbons $\left(\delta_{\mathrm{C}} 10.5,17.4,21.6,22.7,25.8\right.$ and 25.8$)$, seven methylene groups $\left(\delta_{\mathrm{C}} 19.8,22.7,24.7,25.8,30.8,33.3\right.$ and 39.6$)$, one methylidene group $\left(\delta_{\mathrm{C}}\right.$ 110.4), four methine groups including two oxygen-bond methines at $\delta_{\mathrm{C}} 75.5(\mathrm{C}-8)$ and $83.2(\mathrm{C}-13)$, and nine non-protonated carbons including the $\alpha$-pyrone carbonyl at $\delta_{\mathrm{C}} 168.2(\mathrm{C}-25)$, two double bonds of the pyrone moiety $\left[\delta_{\mathrm{C}} 104.1(\mathrm{C}-21)\right.$ and $\delta_{\mathrm{C}} 168.4(\mathrm{C}-22), \delta_{\mathrm{C}} 109.2(\mathrm{C}-23)$ and $\delta_{\mathrm{C}} 156.8(\mathrm{C}-$ $24)]$ and a non-protonated carbon linked to the methylidene group [ $\left.\delta_{\mathrm{C}} 150.8(\mathrm{C}-3)\right]$. The ${ }^{n} \mathrm{~J}_{1 \mathrm{H}-13 \mathrm{C}}$ connectivities provided by HMBC NMR experiment are listed in Table 2.

Table 2. NMR Spectroscopic Data of Compounds 3 and 4 and Comparison with Higginsianin A (10)

\begin{tabular}{|c|c|c|c|c|c|c|c|c|}
\hline \multirow[b]{2}{*}{$\mathrm{N}^{\circ}$} & \multicolumn{3}{|c|}{ Compound 3 (500MHz, $\left.\mathrm{CD}_{3} \mathrm{OD}\right)$} & \multicolumn{3}{|c|}{ Compound $4\left(500 \mathrm{MHz}, \mathrm{CD}_{3} \mathrm{OD}\right)$} & \multicolumn{2}{|c|}{$\begin{array}{l}\text { Higginsianin } \mathrm{A}(500 \mathrm{MHz} \\
\left.\mathrm{CD}_{3} \mathrm{OD}\right)\end{array}$} \\
\hline & $\delta_{\mathrm{C}}$, type & $\delta_{\mathrm{H}, \text { mult }, J \text { in } \mathrm{Hz}}$ & $\mathrm{HMBC}$ & $\delta_{\mathrm{C}}$, type & $\delta_{\mathrm{H}, \text { mult }, J \text { in } \mathrm{Hz}}$ & $\mathrm{HMBC}$ & $\delta_{\mathrm{C}}$, type & $\delta_{\mathrm{H}}$, mult, $J$ in $\mathrm{Hz}$ \\
\hline 1 & $24.7, \mathrm{CH}_{2}$ & $\begin{array}{l}1.38, \mathrm{~m} \\
1.56, \mathrm{~m}\end{array}$ & - & $23.5, \mathrm{CH}_{2}$ & $\begin{array}{l}1.31, \mathrm{~m} \\
1.56, \mathrm{~m}\end{array}$ & - & $25.8, \mathrm{CH}_{2}$ & $\begin{array}{l}1.40, \operatorname{td}(4.2,13.0) \\
1.57, \mathrm{~m}\end{array}$ \\
\hline 2 & $33.3, \mathrm{CH}_{2}$ & $\begin{array}{l}2.09, \mathrm{~m} \\
2.47, \mathrm{td}(5.4,13.6)\end{array}$ & $1,3,19$ & $33.0, \mathrm{CH}_{2}$ & $\begin{array}{l}2.09, \mathrm{~m} \\
2.51, \mathrm{td}(5.4,13.6)\end{array}$ & $1,3,19$ & $33.2, \mathrm{CH}_{2}$ & $\begin{array}{l}2.11, \mathrm{~m} \\
2.47 \mathrm{td}(5.2,13.5)\end{array}$ \\
\hline 3 & $150.8, \mathrm{C}$ & - & - & $150.7, \mathrm{C}$ & - & - & $150.1, \mathrm{C}$ & - \\
\hline 4 & $56.1, \mathrm{CH}$ & $2.17, \mathrm{~m}$ & - & $57.2, \mathrm{CH}$ & $2.09, \mathrm{~m}$ & - & $55.9, \mathrm{CH}$ & $2.18, \mathrm{~m}$ \\
\hline 5 & $38.5, \mathrm{C}$ & - & - & $38.7, \mathrm{C}$ & - & - & $38.7, \mathrm{C}$ & - \\
\hline 6 & $30.8, \mathrm{CH}_{2}$ & $\begin{array}{l}\text { 1.02, td, }(3.2,12.9) \\
2.16, \mathrm{~m}\end{array}$ & $5,8,10$ & $30.6, \mathrm{CH}_{2}$ & $\begin{array}{l}0.93, \mathrm{td},(3.2,12.9) \\
2.39, \mathrm{~m}\end{array}$ & 8,10 & $30.5, \mathrm{CH}_{2}$ & $\begin{array}{l}1.00, \mathrm{~m} \\
2.05, \mathrm{~m}\end{array}$ \\
\hline 7 & $25.8, \mathrm{CH}_{2}$ & $\begin{array}{l}1.77, \mathrm{~m} \\
1.93, \mathrm{~m}\end{array}$ & - & $25.6, \mathrm{CH}_{2}$ & $\begin{array}{l}1.69, \mathrm{~m} \\
1.98, \mathrm{~m}\end{array}$ & - & 23.7, $\mathrm{CH}_{2}$ & $\begin{array}{l}1.84, \mathrm{~m} \\
1.86, \mathrm{~m}\end{array}$ \\
\hline 8 & $75.5, \mathrm{CH}$ & $3.56, \mathrm{bs}$ & $6,7,13$ & $83.1, \mathrm{CH}$ & $3.22, \mathrm{bs}$ & 6,7 & $84.4, \mathrm{CH}$ & 3.72, brt $(2.5)$ \\
\hline 9 & $37.5, \mathrm{C}$ & - & - & $35.8, \mathrm{C}$ & - & - & $45.1, \mathrm{C}$ & - \\
\hline 10 & $45.0, \mathrm{CH}$ & $1.91, \mathrm{~m}$ & - & $35.2, \mathrm{CH}$ & 2.33 , bd (12.9) & - & $39.9, \mathrm{CH}$ & $1.81, \mathrm{~m}$ \\
\hline 11 & $39.6, \mathrm{CH}_{2}$ & $\begin{array}{l}1.38, \mathrm{~m} \\
1.66, \mathrm{~m}\end{array}$ & - & $37.4, \mathrm{CH}_{2}$ & $\begin{array}{l}\text { 1.06, td }(4.0,13.6) \\
2.03, \text { br t }(13.6)\end{array}$ & - & $49.8, \mathrm{CH}_{2}$ & $\begin{array}{l}\text { 1.27, dd }(9.5,12.5) \\
2.26, \text { dd }(6.5,12.5)\end{array}$ \\
\hline 12 & $19.8, \mathrm{CH}_{2}$ & $\begin{array}{l}1.53, \mathrm{~m} \\
1.73, \mathrm{~m}\end{array}$ & - & $22.9, \mathrm{CH}_{2}$ & $\begin{array}{l}1.42, \mathrm{~m} \\
1.67, \mathrm{~m}\end{array}$ & - & 74.7, $\mathrm{CH}$ & $4.91, \mathrm{~m}$ \\
\hline 13 & $83.2, \mathrm{CH}$ & $3.53, \mathrm{dd}(2.2,11.5)$ & 8,12 & $85.5, \mathrm{CH}$ & $3.16, \mathrm{dd}(2.2,11.5)$ & $8,11,14,16$ & $128.4, \mathrm{CH}$ & $5.23, \operatorname{td}(1.3,8.7)$ \\
\hline 14 & $74.8, \mathrm{C}$ & - & - & $73.4, \mathrm{C}$ & - & - & $136.6, \mathrm{C}$ & - \\
\hline 15 & $25.8, \mathrm{CH}_{3}$ & $1.19, \mathrm{~s}$ & $13,14,16$ & $25.3, \mathrm{CH}_{3}$ & $1.19, \mathrm{~s}$ & $13,14,16$ & $26.1, \mathrm{CH}_{3}$ & $1.72, \mathrm{~s}$ \\
\hline 16 & $25.8, \mathrm{CH}_{3}$ & $1.17, \mathrm{~s}$ & $13,14,15$ & $25.7, \mathrm{CH}_{3}$ & $1.26, \mathrm{~s}$ & $13,14,15$ & $18.2, \mathrm{CH}_{3}$ & $1.71, \mathrm{~s}$ \\
\hline 17 & $21.6, \mathrm{CH}_{3}$ & $0.83, \mathrm{~s}$ & $8,9,10,11$ & $23.5, \mathrm{CH}_{3}$ & $0.83, \mathrm{~s}$ & $8,9,10,11$ & $21.1, \mathrm{CH}_{3}$ & $0.98, \mathrm{~s}$ \\
\hline 18 & $22.7, \mathrm{CH}_{3}$ & $0.94, \mathrm{~s}$ & $4,5,6,10$ & $24.1, \mathrm{CH}_{3}$ & $0.99, \mathrm{~s}$ & $4,5,6,10$ & $22.2, \mathrm{CH} 3$ & $0.96, \mathrm{~s}$ \\
\hline 19 & $\begin{array}{l}110.4 \\
\mathrm{CH}_{2}\end{array}$ & $\begin{array}{l}4.20, \mathrm{bs} \\
4.48, \mathrm{bs}\end{array}$ & 2,4 & $\begin{array}{l}110.0 \\
\mathrm{CH}_{2}\end{array}$ & $\begin{array}{l}4.21, \mathrm{bs} \\
4.48, \mathrm{bs}\end{array}$ & $2,3,4$ & $\begin{array}{l}110.7 \\
\mathrm{CH}_{2}\end{array}$ & $\begin{array}{l}4.20, \text { dd } 1.6,2.5) \\
4.50, \text { dd }(2.0,2.5)\end{array}$ \\
\hline 20 & $22.7, \mathrm{CH}_{2}$ & $\begin{array}{l}2.60, \text { dd }(4.4,13.1) \\
2.81, \text { bdd }(13.1)\end{array}$ & $3,4,21,25$ & $22.7, \mathrm{CH}_{2}$ & $\begin{array}{l}2.65, \text { dd }(4.4,13.1) \\
2.85, \text { bdd }(13.1)\end{array}$ & $3,4,21,25$ & $22.6, \mathrm{CH}_{2}$ & $\begin{array}{l}2.59, \mathrm{dd}(4.7,13.1), \\
2.78, \mathrm{dd}(12.1,13.1)\end{array}$ \\
\hline 21 & 104.1, C & - & - & $104.5, \mathrm{C}$ & - & - & $103.9, \mathrm{C}$ & \\
\hline 22 & $168.4, \mathrm{C}$ & - & - & $167.7, \mathrm{C}$ & - & - & $168.2, \mathrm{C}$ & \\
\hline 23 & 109.2, C & - & - & $108.6, \mathrm{C}$ & - & - & $108.9, \mathrm{C}$ & \\
\hline 24 & $156.8, \mathrm{C}$ & - & - & $156.8, \mathrm{C}$ & - & - & $156.8, \mathrm{C}$ & \\
\hline 25 & $168.2, \mathrm{C}$ & - & - & $168.2, \mathrm{C}$ & - & - & $167.8, \mathrm{C}$ & \\
\hline 26 & $10.5, \mathrm{CH}_{3}$ & $1.92, \mathrm{~s}$ & $22,23,24$ & $10.4, \mathrm{CH}_{3}$ & $1.93, \mathrm{~s}$ & $22,23,24$ & $10.5, \mathrm{CH}_{3}$ & $1.91, \mathrm{~s}$ \\
\hline 27 & $17.4, \mathrm{CH}_{3}$ & $2.19, \mathrm{~s}$ & 23,24 & $17.3, \mathrm{CH}_{3}$ & $2.20, \mathrm{~s}$ & 23,24 & $17.4, \mathrm{CH}_{3}$ & $2.19, \mathrm{~s}$ \\
\hline
\end{tabular}


Interestingly, the ${ }^{1} \mathrm{H}$ and ${ }^{13} \mathrm{C}$ NMR spectra of $\mathbf{3}$ resemble those recorded for higginsianin $\mathrm{A}$ 10 (Table 2) and are consistent with a polycyclic diterpene ring system joined to a tetra-substituted $\alpha$-pyrone ring. As in 10, HMBC correlations in 3 from Me-27 to C-23 and C-24, Me-26 to C-22, C23 and C-24 and C-20 to C-21 and C-25 allowed construction of the tetra-substituted $\alpha$-pyrone ring. Ring A was built according to the COSY correlations between H-1, H-2 and H-19 and the HMBC connectivities from H-19 to C-4 and C-2, Me-18 to C-4, C-5 and C-10. Ring A was linked to the tetra-substituted $\alpha$-pyrone ring through $\mathrm{C}-20$ according to $\mathrm{HMBC}$ correlations from $\mathrm{H}-20$ to $\mathrm{C}-3, \mathrm{C}$ 4, C21 and C-25. Ring B was built and connected to ring A based on COSY correlations between H-6, H-7 and H-8 and HMBC correlations from Me-18 to C-4, C-5, C-6 and C-10, H-6 to C-5, C10 and C-8, Me-17 to C-8, C-9 and C-10 (Figure 3).

COSY correlations

$\longrightarrow$ HMBC correlations

$\longleftrightarrow$ ROE correlations
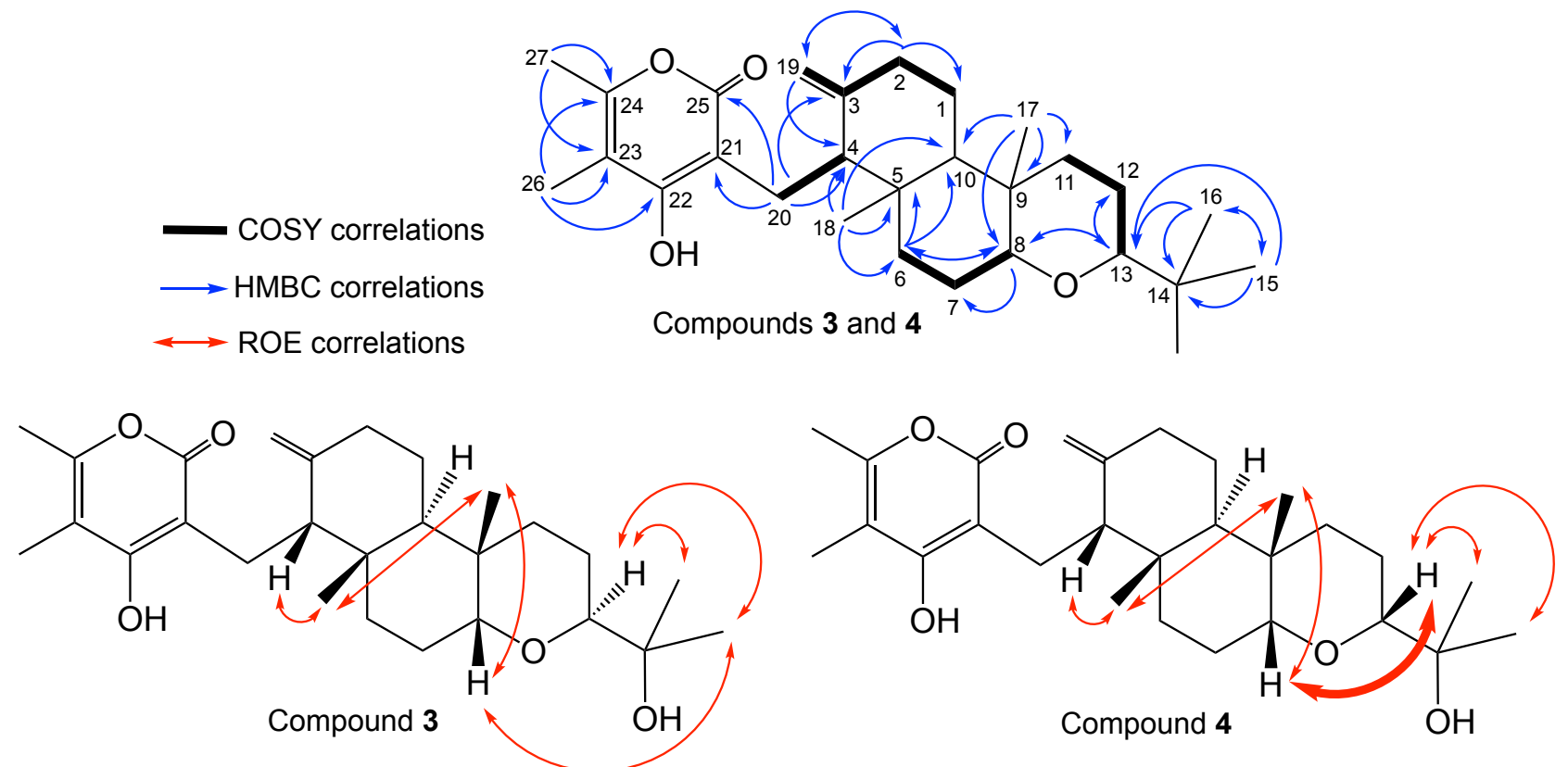

Figure 3. Key COSY, HMBC and ROE correlations for compounds 3 and 4

The main difference between higginsianin A 10 and compound 3 lies in ring C. In 10, ring C is a tetrahydrofuran substituted at $\mathrm{C}-12$ by a isobutenyl group, while in $\mathbf{3}$, ring $\mathrm{C}$ is a tetrahydropyran substituted at $\mathrm{C}-13$ by a isopropanol group. Ring $\mathrm{C}$ of compound $\mathbf{3}$ was built and connected to ring B through C-8 and C-9, observing COSY correlations between $\mathrm{H}-11, \mathrm{H}-12$ and H-13 and HMBC correlations from Me-17 to C-8, C-9 and C-11 and from H-13 to C-12 and C-8. 
The C-13 position was substituted by an isopropanol group, observing correlations from Me-15 to C-13, C-14 and C-16 and from Me-16 to C-13, C-14 and C-15.

The configuration of $\mathbf{3}$ was established according to ROE correlations and comparison with the absolute configuration of higginsanin A (10), obtained from reported X-ray analysis. ${ }^{14}$ The common ROE correlations between Me-18, H-4, Me-17 and H-8 and the absence of correlation with $\mathrm{H}-10$ supported that the configurations of $\mathrm{C}-4, \mathrm{C}-5, \mathrm{C}-8, \mathrm{C}-9$, and $\mathrm{C}-10$ are similar to those reported for higginsianin A. Concerning the configuration of $\mathrm{C}-13$, no ROE correlation was observed between $\mathrm{H}-8$ and H-13, suggesting a trans orientation of these two protons. Compound 3 is a new diterpenoid $\alpha$-pyrone and was named higginsianin $\mathrm{C}$.

Compound 4 was obtained as a white powder. Its molecular formula, $\mathrm{C}_{27} \mathrm{H}_{40} \mathrm{O}_{5}$, was identical to those found for higginsianin $\mathrm{C}$ and was deduced by HRESIMS with $m / z 445.2958[\mathrm{M}+\mathrm{H}]^{+}$. The ${ }^{1} \mathrm{H}$ and ${ }^{13} \mathrm{C}$ NMR spectra of $\mathbf{4}$ were very similar to those of $\mathbf{3}$ (Table 2). Moreover, COSY and HMBC data confirmed that $\mathbf{4}$ had the same connectivities, supporting a similar planar scaffold (Figure 3). The configuration of $\mathbf{4}$ was established according to ROE correlations and comparison with compound 3. Here again, we noticed common ROE correlations between Me-18, H-4, Me-17 and $\mathrm{H}-8$ and the absence of correlation with $\mathrm{H}-10$ supported that the configuration of C-4, C-5, C-8, C9, and C-10 are similar to those deduced for 3. A key ROE correlation was observed in $\mathbf{4}$ between H-8 and H-13, suggesting a cis configuration of these two protons. Compound 4 was named 13-epihigginsianin $\mathrm{C}$.

The diterpenoid moiety of $\mathbf{3}$ and $\mathbf{4}$ is similar to the previously reported $\gamma$-pyrone candelalide $\mathrm{C}^{28}$ The absolute configuration at C-13 is similar to the established configuration of 4 due to the common key ROE correlation between H-8 and H-13.

In order to validate the configuration of compounds $\mathbf{3}$ and $\mathbf{4}$ established by ROESY experiments, molecular modeling studies were carried out to evaluate the conformational flexibility of different conformers for compounds $\mathbf{3}$ and $\mathbf{4}$ and to compare these results with the experimental NMR data. The most stable conformers of compounds $\mathbf{3}$ and $\mathbf{4}$ are presented in Figure 4. 


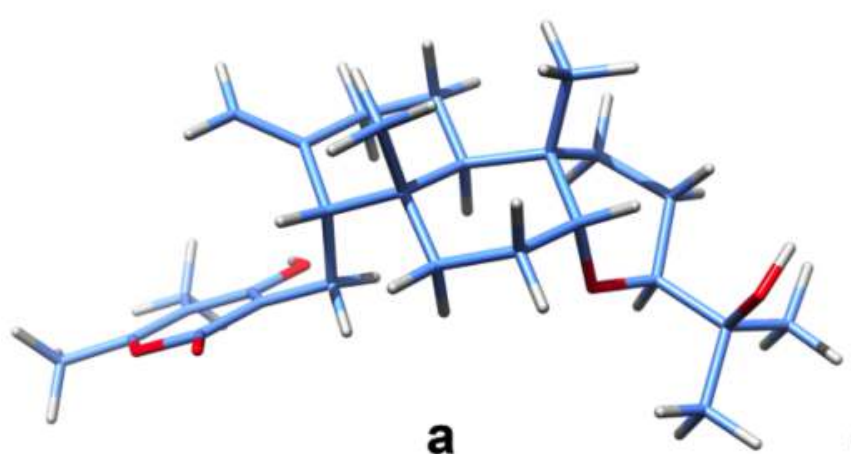

a

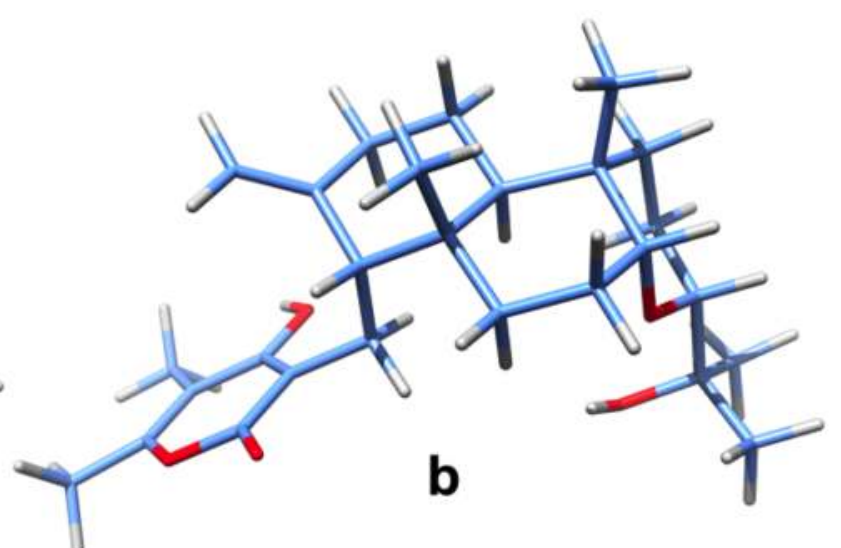

b

Figure 4. Three-dimensional structures of the most stable conformers of compounds 3 (a) and 4 (b) Their structures are in full agreement with the relative configurations and ROE correlations mentioned above. The atoms $\mathrm{H}-4, \mathrm{C}-18, \mathrm{C}-17$ and $\mathrm{H}-8$ are indeed on the same side in both compounds $\mathbf{3}$ and $\mathbf{4}$, with all the corresponding distances compatible with the ROE correlations observed: H-4 to C-18 $2.57 \AA$ and $2.59 \AA, \mathrm{C}-18$ to C-17 $3.42 \AA$ and $3.37 \AA, \mathrm{C}-17$ to $\mathrm{H}-82.64 \AA$ and $2.56 \AA$, respectively. Additionally, in compound 4 the distance from $\mathrm{H}-8$ to $\mathrm{H} 13$ is $2.42 \AA$, thus confirming the configuration of this chiral center. The absolute stereochemistry of these compounds was further confirmed by the computation of TDDFT ECD spectra, which proved to be very similar with the experimental ones and with those reported for higginsianins A and B (Supporting Information, S46). ${ }^{14}$

The ${ }^{1} \mathrm{H}$ and ${ }^{13} \mathrm{C}$ NMR chemical shifts corresponding to these conformers were computed using the DFT-NMR approach that we used previously. ${ }^{29}$ The chemical shifts were generally well predicted, with mean unsigned errors (MUEs) of 0.09 and 0.11 for ${ }^{1} \mathrm{H}$ NMR and of 2.68 and 2.51 for ${ }^{13} \mathrm{C}$ NMR, respectively, and with root mean square errors (RMSEs) of 0.11 and 0.14 for ${ }^{1} \mathrm{H}$ NMR and of 3.15 and 3.03 for ${ }^{13} \mathrm{C}$ NMR, respectively (Tables S41 and S42 in Supp. Info.).

The tetracyclic higginsianins A and C may derive from the tricyclic analog B through classical enzymatic reactions as depicted in Figure 5. 


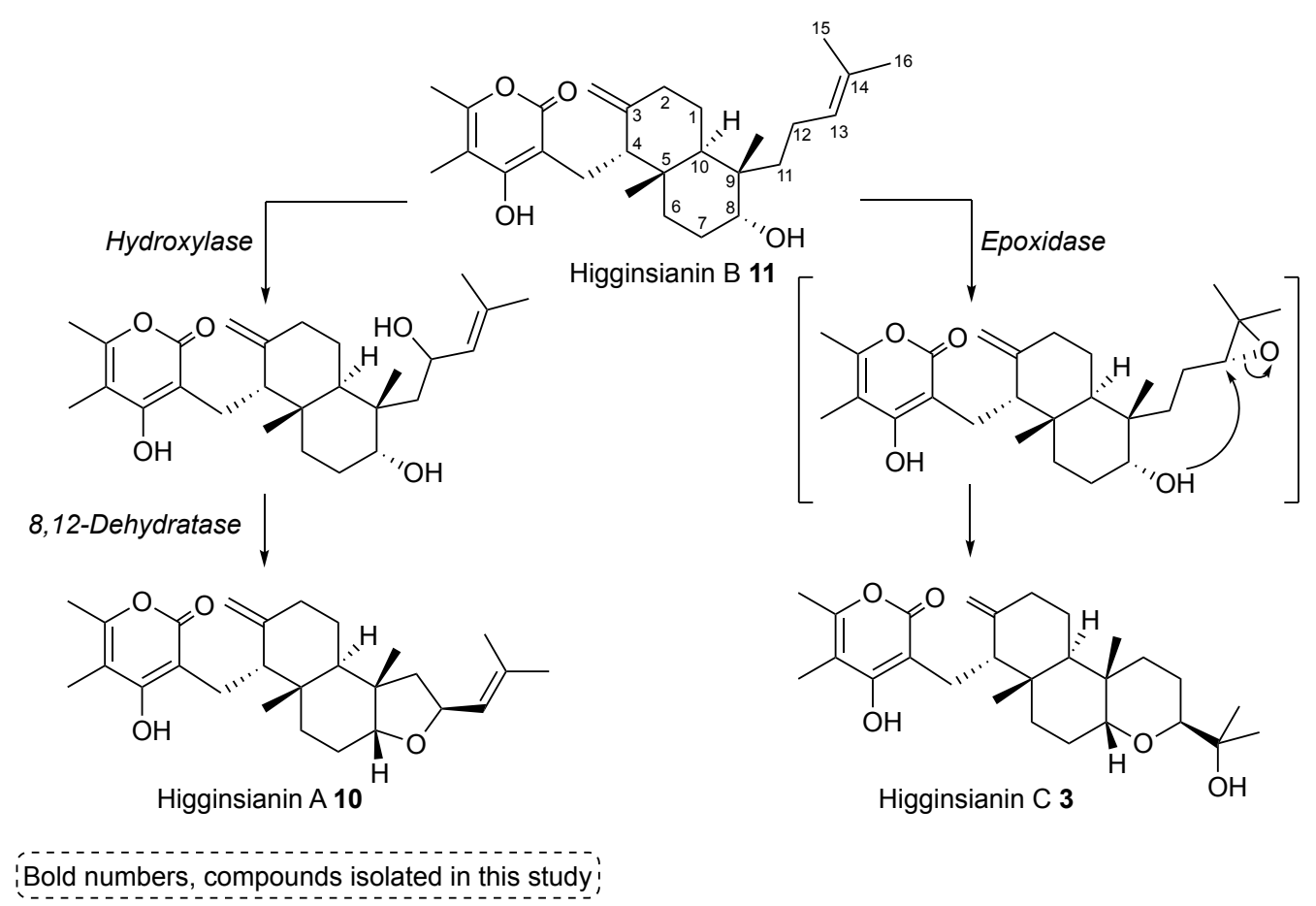

Figure 5. Proposed biosynthesis of the higginsianin family starting from the B form.

Compound 5 was obtained as a transparent oil. Its molecular formula, $\mathrm{C}_{23} \mathrm{H}_{36} \mathrm{O}_{7}$, was deduced by HRESIMS with $m / z 425.2552[\mathrm{M}+\mathrm{H}]^{+}$. This formula was corroborated by the ${ }^{13} \mathrm{C}$ NMR spectrum and revealed six degrees of unsaturation. Based on the following spectroscopic data, these degrees of unsaturation corresponded to an $\alpha$-cadinene sesquiterpene moiety, an ester carbonyl group and an inositol derivative ring.

The ${ }^{13} \mathrm{C}$ NMR spectrum revealed the presence of 23 carbons which, in combination with the HSQC spectrum, can be attributed to five methyl carbons, including two methoxy groups $\left(\delta_{\mathrm{C}} 15.5,21.7\right.$, 24.0, 58.0 and $61.2 \mathrm{ppm})$, three methylene groups $\left(\delta_{\mathrm{C}} 26.5,26.8\right.$ and $\left.31.7 \mathrm{ppm}\right), 12$ methine groups: $10 \mathrm{sp}^{3}$ methines including six bonded to oxygen $\left(\delta_{\mathrm{C}} 27.7,35.8,37.4,41.8,70.9,71.6,74.0,74.5\right.$, 81.7 and 86.5), two $\mathrm{sp}^{2}$ methines $\left(\delta_{\mathrm{C}} 124.3\right.$ and 141.5$)$ and three non-protonated carbons including one carbonyl group at $\delta_{\mathrm{C}} 168.1 \mathrm{ppm}$ and two sp ${ }^{2}$ carbons $\left(\delta_{\mathrm{C}} 134.5\right.$ and 136.2$)$. The ${ }^{n} \mathrm{~J}_{1 \mathrm{H}-13 \mathrm{C}}$ connectivities given by an HMBC NMR experiment are listed in Table 3. 


\begin{tabular}{|c|c|c|c|}
\hline \multicolumn{4}{|c|}{ Compound 5 (500 MHz, $\left.\mathrm{CD}_{3} \mathrm{OD}\right)$} \\
\hline $\mathrm{N}^{\circ}$ & $\delta_{\mathrm{C}}$, type & $\delta_{\mathrm{H}}$, mult, $J$ in $\mathrm{Hz}$ & $\mathrm{HMBC}$ \\
\hline 1 & $35.8, \mathrm{CH}$ & $2.55, \mathrm{~d}(11.1)$ & - \\
\hline 2 & $26.8, \mathrm{CH}_{2}$ & $1.42, \mathrm{dd}(5.0,12.2) ; 2.00, \mathrm{~m}$ & $1,2,6$ \\
\hline 3 & $31.7, \mathrm{CH}_{2}$ & $1.91, \mathrm{~m} ; 2.08, \mathrm{~m}$ & $1,2,4$ \\
\hline 4 & 136.2, C & - & - \\
\hline 5 & $124.3 \mathrm{CH}$ & 5.55, br m & 1,15 \\
\hline 6 & $37.4, \mathrm{CH}$ & $2.01, \mathrm{~m}$ & - \\
\hline 7 & $41.8, \mathrm{CH}$ & $1.55, \mathrm{~m}$ & $6,11,12$ \\
\hline 8 & $26.5, \mathrm{CH}_{2}$ & $2.16, \operatorname{td}(3.9,19.1)$ & $6,7,9,10$ \\
\hline 9 & $141.5, \mathrm{CH}$ & $6.99, \mathrm{~m}$ & $1,7,14$ \\
\hline 10 & $134.5, \mathrm{C}$ & - & - \\
\hline 11 & $27.7, \mathrm{CH}$ & $2.05, \mathrm{~m}$ & - \\
\hline 12 & $15.5, \mathrm{CH}_{3}$ & $0.87, \mathrm{~d}(6.6)$ & $7,11,13$ \\
\hline 13 & $21.7, \mathrm{CH}_{3}$ & $0.95, \mathrm{~d}(6.6)$ & $7,11,12$ \\
\hline 14 & $168.1, \mathrm{C}$ & - & - \\
\hline 15 & $24.0, \mathrm{CH}_{3}$ & $1.70, \mathrm{~s}$ & $3,4,5$ \\
\hline 1 ' & $70.9, \mathrm{CH}$ & 5.66, br t $(2.3)$ & $1^{\prime}, 6,, 14$ \\
\hline 2 ' & $81.7, \mathrm{CH}$ & $3.18, \mathrm{dd}(2.3,9.6)$ & $1^{\prime}, 3^{\prime}, 7^{\prime}$ \\
\hline 3 & $74.0, \mathrm{CH}$ & $3.62, \mathrm{~m}$ & - \\
\hline $4^{\prime}$ & $86.5, \mathrm{CH}$ & 2.94, br t $(9.4)$ & $3^{\prime}, 5^{\prime}, 8^{\prime}$ \\
\hline 5 & $74.5, \mathrm{CH}$ & $3.64, \mathrm{~m}$ & - \\
\hline $6^{\prime}$ & $71.6, \mathrm{CH}$ & $3.65, \mathrm{~m}$ & - \\
\hline 7 ' & $58.0, \mathrm{CH}_{3}$ & $3.41, \mathrm{~s}$ & 2 \\
\hline $8^{\prime}$ & $61.2, \mathrm{CH}_{3}$ & $3.65, \mathrm{~s}$ & $4^{\prime}$ \\
\hline
\end{tabular}

HMBC correlations observed from Me-15 to C-3, C-4 and C-5, from H-2 to C-1, C-3 and C-6, in combination with the COSY correlations between $\mathrm{H}-1$ and $\mathrm{H}-2$ and between $\mathrm{H}-5$ and $\mathrm{H}-6$ allowed us to build the first six-membered ring of the cadinene skeleton. The COSY data revealed the spin system spanning Me-12/Me-13/H-7/H-8/H-9 and observing HMBC correlations from H-7 to C-6 and from $\mathrm{H}-9$ to $\mathrm{H}-7$ and $\mathrm{H}-1$, we were able to connect the second isopropyl substituted sixmembered ring at the C-1/C-6 positions to give the $\alpha$-cadinene sesquiterpene moiety (Figure 6 ). The third six-membered ring consisted of a dimethoxy-inositol derivative according to COSY correlations between H-4' and H-5' and between H-6', H-1' and H-2' via H-1' and HMBC correlations from $\mathrm{H}-1$ ' to $\mathrm{C}-2$ ' and C-6', from $\mathrm{H}-2$ ' to $\mathrm{C}-1$ ' and $\mathrm{C}-3$ ' and from $\mathrm{H}-4$ ' to $\mathrm{C}-3$ ' ' and C5'. The methoxy groups $\mathrm{MeO}-7$ ' and $\mathrm{MeO}-8$ ' were linked to C-2' and C-3' respectively, according to HMBC correlations from Me-7' to C-2' and from Me-8' to C-3'. Finally, this dimethoxy-inositol derivative was linked to the $\alpha$-cadinene sesquiterpene moiety through an ester group between $\mathrm{C}-10$ and C-1' according to HMBC correlations from H-9 and H-1' to C-14. 


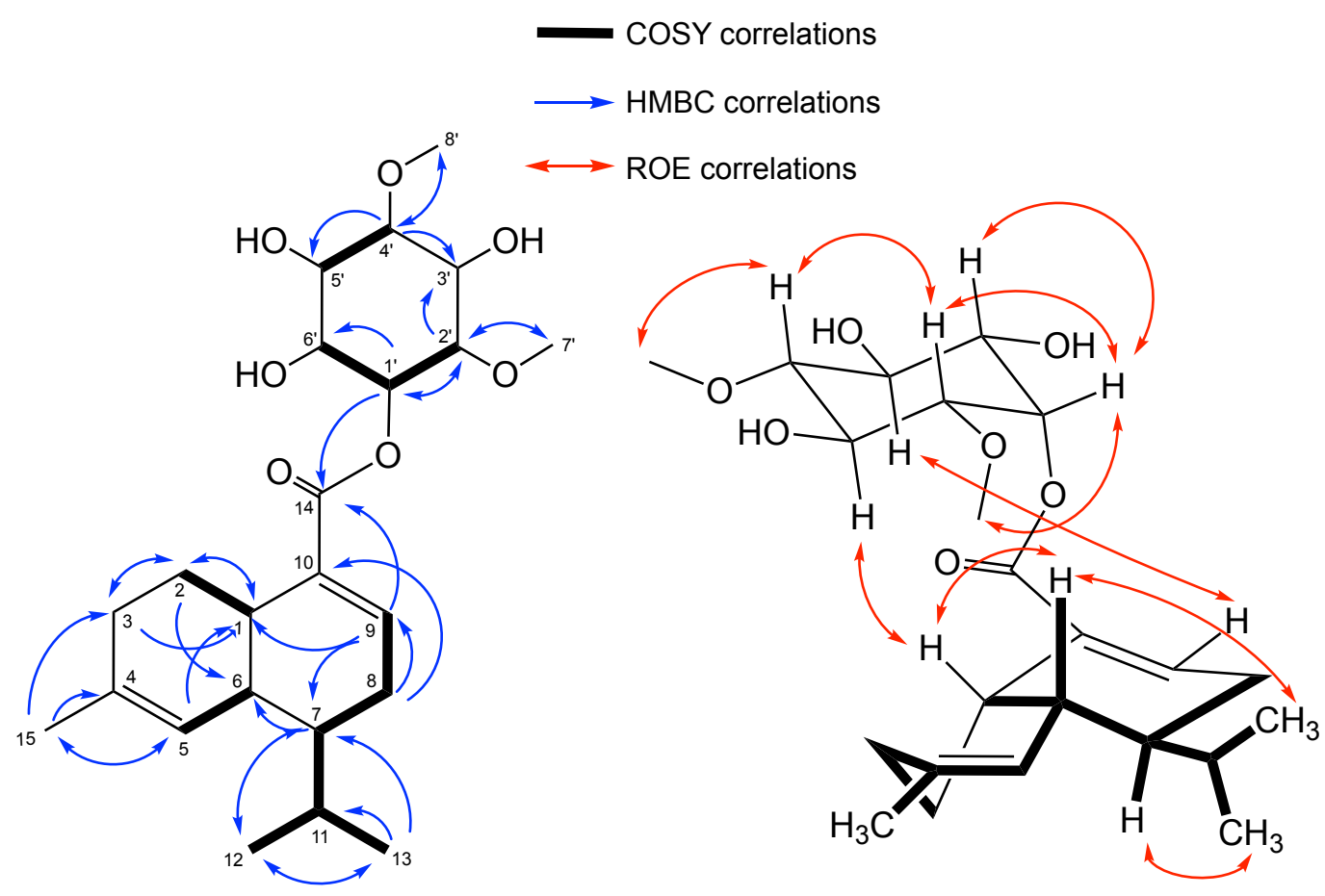

Figure 6. Key COSY, HMBC and ROE (mixing time $=300 \mathrm{~ms}$ ) correlations for compound $\mathbf{5}$

The ROESY spectrum allowed us to determine the relative configuration of C-1, C-6 and C-7. ROE correlations were observed between H-1 and H-6 and absence of correlation was noticed between H-1 and H-7 and H-6 and H-7.

A time-dependent density functional theory (TDDFT) ECD calculation of compound $\mathbf{5}$ with the stereogenic centers on the bicyclic system assigned as $1 S, 6 R, 7 S$ resulted in a spectrum nearly identical with the experimental ECD spectrum determined for this compound, with a positive peak at $217 \mathrm{~nm}$ (Figure 7). The absolute configurations of the carbons at the bicyclic junction and the ECD spectrum are opposite with those reported for $(+)$-sclerosporin and analogs ${ }^{34}$ and therefore compound 5 is a (-)-sclerosporin derivative. The $S$-cis and $S$-trans conformation of the unsaturated ester has no significant influence on the overall shape of the ECD spectrum (data not shown). 


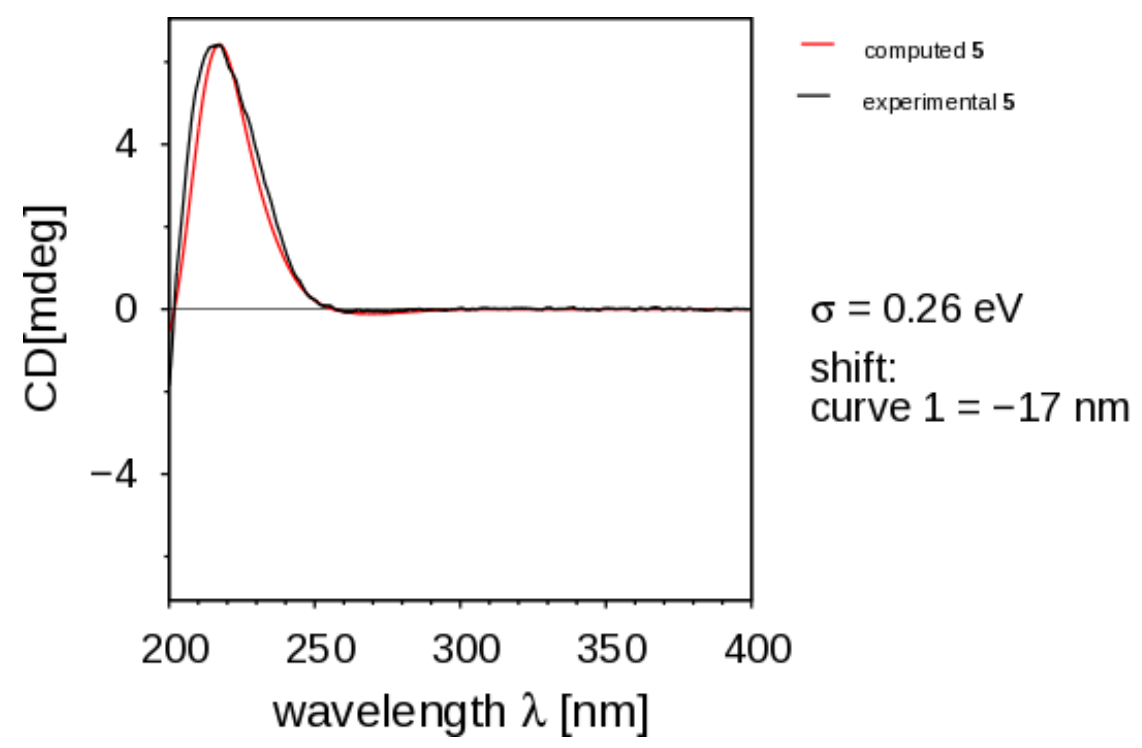

Figure 7. Superposed experimental ECD spectrum (black) with the computed ECD spectrum (red) for compound 5 .

Concerning the inositol moiety, the configuration was established based on the ROE correlation and the ${ }^{3} J_{H}$ coupling constants (Table 3$) . \mathrm{H}-1$ ' $\left(\delta_{\mathrm{H}} 5.66\right)$ gave a broad triplet with a ${ }^{3} J_{H}$ of $2.3 \mathrm{~Hz}$, suggesting an eq-ax conformation of H-1' with H-2' and H-6'. Moreover, H-2' $\left(\delta_{\mathrm{H}} 3.18\right.$, dd) showed two ${ }^{3} J_{H}$ of $2.3 \mathrm{~Hz}$ and $9.6 \mathrm{~Hz}$, corroborating an equatorial position for $\mathrm{H}-1$ ' and so axial positions of H-2' and H-3'. H-4' gave a broad triplet with a ${ }^{3} J_{H}$ of $9.6 \mathrm{~Hz}$, suggesting an ax-ax conformation of H-3', H-4' and H-5'. This conformation was consistent with the ROE correlations observed between H-1' with H-2', Me-7' and H-6', H-2' with H-4' and H-6', H-1 with H-3' and H9 with H-5'. Compound 5 was named sclerosporide.

The most stable conformer of compound $\mathbf{5}$ is presented in Figure 8.

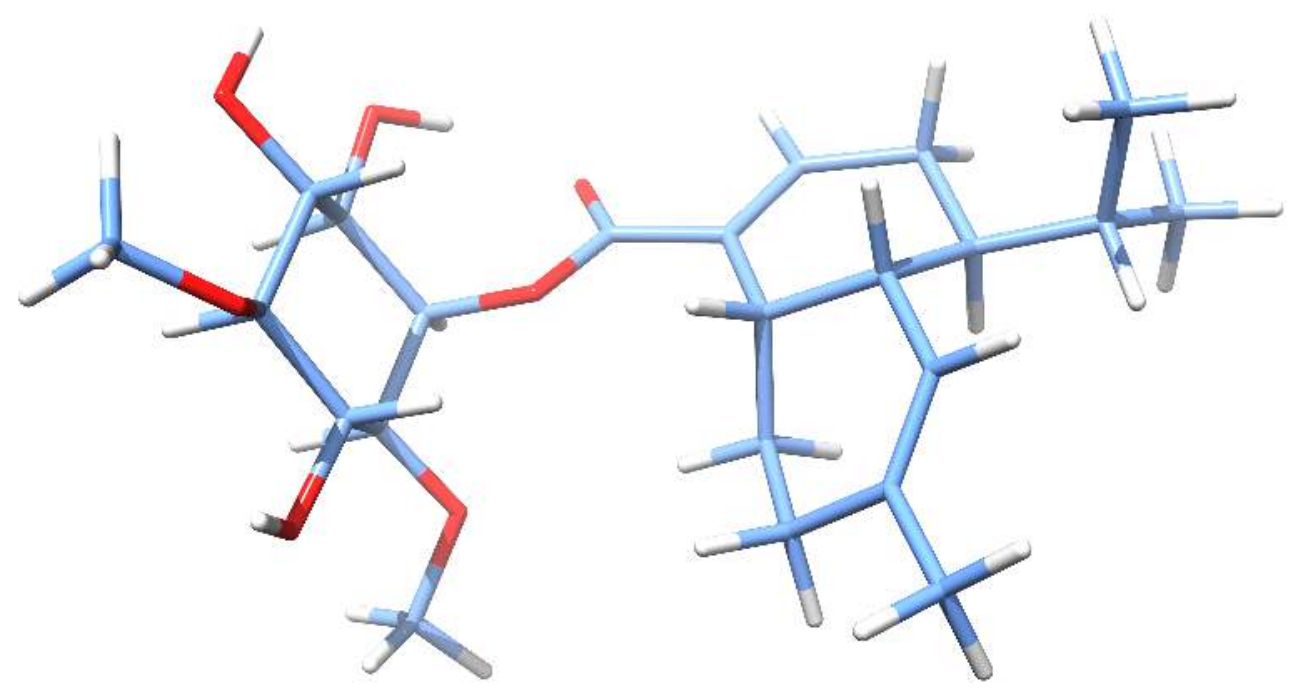


Figure 8. Three-dimensional structure of the most stable conformer of compound 5

The main feature of this structure is the hydrogen bond between the $\mathrm{OH}$ group in position 6' and the carbonyl oxygen atom from the ester group which brings the two fragments, cadinene and inositol, closer and allows them to interact, according to the ROE correlations. The distances $\mathrm{H}-1$ ' to H-2', C-7' to H-6', H-2' to H-4', H-2' to H-6', H-1 to H-3' and H-9 to H-5' are $2.46 \AA$, $4.66 \AA, 2.64 \AA$, $2.44 \AA, 3.04 \AA, 5.45 \AA$, respectively. The relative configuration of the chiral centers is in agreement with the coupling constants determined experimentally.

As for compounds 3 and $\mathbf{4}$, the ${ }^{1} \mathrm{H}$ and ${ }^{13} \mathrm{C}$ NMR chemical shifts corresponding to 5 were computed using the DFT-NMR approach (Tables S43 and S44 supporting information). Again, a good correlation was observed between the experimental and computed values of the chemical shifts, with mean unsigned errors (MUEs) of 0.14 for ${ }^{1} \mathrm{H}$ NMR and of 2.83 for ${ }^{13} \mathrm{C}$ NMR, respectively, and with root mean square errors (RMSEs) of 0.22 for ${ }^{1} \mathrm{H}$ NMR and of 4.03 for ${ }^{13} \mathrm{C}$ NMR, respectively. Sclerosporin was first isolated from Sclerotinia fructicula as an inducer of asexual arthrospore formation, ${ }^{31}$ and from Diplocarpon mali, the Marssonina apple blotch disease agent. ${ }^{32,33}$ Sclerosporin has been reported in less than eight publications so far, half of them focused on the isolation of the compound and analogs from various fungal strains, ${ }^{31,33,34}$ while the others are dedicated to chemical synthesis. ${ }^{35-37}$ The sclerosporin family contains oxido-reduction derivatives of the original compound, sclerosporal was isolated from Sclerotinia fructicula, polygosumic acid from Polygonum viscosum, and four hydroxylated derivatives from Cadophora malorum.

Compound $\mathbf{5}$ is the first example of a conjugated sclerosporin; more unexpected is its conjugation with dimethoxy inositol because until now methoxy inositol derivatives have been exclusively reported from the plant kingdom. (+)-Pinpollitol, a di-O-methyl D-(+)-chiro-inositol was isolated from the pollen of Pinus radiata exhibiting growth regulating properties. ${ }^{38}$ Mono methoxy inositols isolated from plants like D-pinitol, L-quebrachitol and $O$-methyl-scyllo-inositol exhibit valuable biological activities. ${ }^{39-41}$

This is the first time that a sclerosporin-based compound has been reported from any 
Colletotrichum species, and the first time that an O-alkylated inositol has been found in a phylum other than plants.

Compounds were assayed for different biological and enzymatic activities. Antibacterial activity was tested against Escherichia coli ATCC 25922, Bacillus subtilis ATCC 6633 and Micrococcus luteus ATCC 10240 by the broth microdilution method according to Clinical and Laboratory Standards Institute (CLSI) guidelines. Antifungal activity was tested against Rhizopus oryzae ATCC 11145, Aspergillus ochraceus ATCC 1009 and Botrytis cinerea B05.10 according to the European Committee for Antimicrobial Susceptibility Testing method (EUCAST). For antibacterial and antifungal bioassays, the minimal inhibitory concentrations (MIC) are higher than $225 \mu \mathrm{M}$ (antibacterial control $\mathrm{MIC}_{\text {chloramphenicol }}=10 \mu \mathrm{M}$; antifungal control $\mathrm{MIC}_{\text {amphotericin } \mathrm{B}}=2 \mu \mathrm{M}$ ). Compounds were also screened on a panel of cosmetic targets as anti-tyrosinase, anti-collagenase, anti-hyaluronidase, anti-elastase and antioxidant (DPPH method). We used the following controls at concentrations giving $50 \%$ inhibition in our condition: tyrosinase inhibition, kojic acid for (20 $\mu \mathrm{M})$; elastase inhibition, elastatinal $(15 \mu \mathrm{M})$; collagenase inhibition, 1,10-phenanthroline $(100 \mu \mathrm{M})$; hyaluronidase inhibition, ascorbic acid (5mM); DPPH method, trolox (20 $\mu \mathrm{M})$. Compounds were tested from 10 to $200 \mu \mathrm{M}$ and the inhibition never exceeded $20 \%$ at the higher concentrations. Our findings demonstrate the major impact that chromatin status has on the production of secondary metabolites by $C$. higginsianum. Deletion of cclA drastically altered the profile of metabolites produced in liquid cultures of this fungus, as shown by the massive over-production of some known terpenoid compounds, and the identification of new analogs of these compounds and novel structural scaffolds that were uniquely produced by the mutant. Our work highlights the enormous potential of genetic manipulation of key chromatin regulators as a strategy for unlocking the chemical diversity encoded by fungal genomes.

\section{EXPERIMENTAL SECTION}

\section{General Experimental Procedures.}


Optical rotations were measured at $25^{\circ} \mathrm{C}$ on a JASCO P1010 polarimeter. UV spectra were measured in a $1 \mathrm{~cm}$ quartz tank using a Varian Cary 100 scan spectrophotometer. ECD spectra were measured with a Jasco J-810 CD Spectrometer. IR spectra were obtained on a Perkin-Elmer Spectrum 100 model instrument. ${ }^{1} \mathrm{H}$ and ${ }^{13} \mathrm{C}$ spectra were recorded using a Bruker Avance-500 and 600 instrument operating at 500 and $600 \mathrm{MHz}$ respectively. The Bruker Avance $600 \mathrm{MHz}$ was equipped with a microprobe (1.7 TXI). LC-ESI-MS analysis were performed on a simple-stage quadrapole Waters-Micromass ZQ 2000 mass spectrometer equipped with an ESI (electrospray ionization) interface coupled to an Alliance Waters 2695 HPLC instrument with PDA and ELS detection. The HRESIMS spectra were recorded on a Waters-Micromass mass spectrometer equipped with ESI-TOF (electrospray-time of flight). HPLC chromatograph consisted of a Waters system including an autosampler 717, a pump 600, a photodiode array 2998 and an evaporative light-scattering detector, ELSD 2420. The HPLC analytical column used was a $3.5 \mu \mathrm{m}, \mathrm{C}-18$ column (Sunfire $150 \times 4.6 \mathrm{~mm}$ ) operating at $0.7 \mathrm{~mL} / \mathrm{min}$. The semipreparative column was a $5 \mu \mathrm{m}$, C-18 (Sunfire $250 \mathrm{~mm} \times 10 \mathrm{~mm}$ ) operating at $4 \mathrm{~mL} / \mathrm{min}$. On both columns, the gradient consisted of a linear gradient for $50 \mathrm{~min}$ from $\mathrm{H}_{2} \mathrm{O}$ to $\mathrm{CH}_{3} \mathrm{CN}$, both containing $0.1 \%$ formic acid. Silica gel 60 (6-35 and 35-70 $\mu \mathrm{m}$ ) and analytical TLC plates (Si gel $60 \mathrm{~F} 254$ ) were purchased from SDS (France). Prepacked silica gel 80 g Redisep columns were used for flash chromatography using a Combiflash-Companion apparatus (Serlabo). The Antibase database was used for rapid dereplication and characterization of known compounds. All other chemicals and solvents were purchased from SDS (France).

\section{Fungal Strains}

Colletotrichum higginsianum IMI 349063 was used as the wild-type strain. The strain called $\Delta c c l A$ used in this study was obtained by deleting the gene CH63R_04661 coding the sole ortholog of the Aspergillus nidulans CclA protein (AN9399) in C. higginsianum. Complete details about the generation and phenotyping of this deletion mutant are reported elsewhere (Dallery et al., 
submitted). Both strains were routinely maintained on Mathur's medium as previously described. ${ }^{1}$ When necessary $\Delta c c l A$ was propagated on potato dextrose agar supplemented with $100 \mu \mathrm{g} \cdot \mathrm{mL}^{-1} \mathrm{of}$ hygromycin B as a selection agent.

\section{Fermentation, Extraction and Isolation}

Fungal strains were cultivated in Potato Dextrose Broth (PDB, Difco) amended with $30 \mathrm{~g} \cdot \mathrm{L}^{-1} \mathrm{of}$ XAD-16 resin. The inoculum originated from potato dextrose agar plates and consisted of a mixture of spores and mycelium. A total of four Erlenmeyer flasks of 2L each containing 1L of PDB medium were inoculated and allowed to grow at $25^{\circ} \mathrm{C}$ with shaking $(150 \mathrm{rpm})$ for 5 days. At the end of the incubation period, fungal biomass and resin were recovered and separated from the supernatant by filtration.

The mix of biomass and resin was extracted with $3 \times 500 \mathrm{~mL}$ of EtoAc. The extract was dried over $\mathrm{Na}_{2} \mathrm{SO}_{4}$ and evaporated under reduced pressure yielding $390 \mathrm{mg}$ of organic extract. The extract was subjected to flash chromatography using a gradient of n-heptane:EtoAc (100:0-0:100) at 40 $\mathrm{mL} / \mathrm{min}$ during $75 \mathrm{~min}$ to afford 9 fractions, according to their TLC profiles. Fractions 1-5 were pooled and purified from a preparative C-18 column (Sunfire, $250 \mathrm{~mm} \times 10 \mathrm{~mm} \times 5 \mu \mathrm{m}$ ) using a linear gradient for $40 \mathrm{~min}$ from $\mathrm{H}_{2} \mathrm{O}$ to $\mathrm{CH}_{3} \mathrm{CN}$, both containing $0.1 \%$ formic acid followed by 10 min of $\mathrm{CH}_{3} \mathrm{CN}$ containing $0.1 \%$ formic acid to afford $1 \mathrm{mg}$ of eremophilane, $3 \mathrm{mg}$ of colletorin A $\mathbf{6}$, $2.5 \mathrm{mg}$ of 2, $2 \mathrm{mg}$ of $\mathbf{1 , 3} \mathrm{mg}$ of colletochlorin D 9 and $1 \mathrm{mg}$ of colletochlorin B 8. Fraction 6 (70.9 mg, n-heptane:EtoAc 40:60) was purified from a preparative C-18 column (Sunfire, 250mm x $10 \mathrm{~mm} \times 5 \mu \mathrm{m})$ using an isocratic elution of water: $\mathrm{CH}_{3} \mathrm{CN}(30: 70)$, both containing $0.1 \%$ formic acid to afford $4 \mathrm{mg}$ of colletochlorin A 7, $3 \mathrm{mg}$ of 3,4 mg of higginsianin A $\mathbf{1 0}$ and $17 \mathrm{mg}$ of higginsianin B 11. Fraction 8 (14.1 mg, n-heptane: EtoAc 20:80) was purified from a preparative C18 column (Sunfire, $250 \mathrm{~mm}$ x $10 \mathrm{~mm}$ x $5 \mu \mathrm{m}$ ) using a linear gradient for $40 \mathrm{~min}$ from $\mathrm{H}_{2} \mathrm{O}$ to $\mathrm{CH}_{3} \mathrm{CN}$, both containing $0.1 \%$ formic acid followed by $10 \mathrm{~min}$ of acetonitrile containing $0.1 \%$ formic acid to afford $1.5 \mathrm{mg}$ of 4 . Fraction 9 (24 mg, n-heptane: EtoAc 0:100) was purified from a 
preparative C-18 column (Sunfire, $250 \mathrm{~mm}$ x $10 \mathrm{~mm} \times 5 \mu \mathrm{m}$ ) using a linear gradient for $40 \mathrm{~min}$ from $\mathrm{H}_{2} \mathrm{O}$ to $\mathrm{CH}_{3} \mathrm{CN}$, both containing $0.1 \%$ formic acid followed by 10 min of $\mathrm{CH}_{3} \mathrm{CN}$ containing $0.1 \%$ formic acid to afford $1.5 \mathrm{mg}$ of $\mathbf{5}$.

Colletorin D (1): yellow solid, UV $\lambda_{\max } \mathrm{nm}(\log \varepsilon) 228$ (4.2), 292 (4.1), 337 (3.6); IR $v_{\max } 3325$, 2913, 1724, 1655, 1593, $1216 \mathrm{~cm}^{-1}$; NMR data, Table 1; HRESIMS m/z $221.1174[\mathrm{M}+\mathrm{H}]^{+}($calcd for $\left.\mathrm{C}_{13} \mathrm{H}_{17} \mathrm{O}_{3}, 221.1178\right)$.

Colletorin D acid (2): yellow oil, UV $\lambda_{\max } \mathrm{nm}(\log \varepsilon) 228$ (4.2), 292 (4.1), 337 (3.6); IR $v_{\max } 3325$, 1644, 1531, 1201, $1121 \mathrm{~cm}^{-1}$; NMR data, Table 1; HRESIMS m/z 235.0964 [M-H] ${ }^{-}$(calcd for $\left.\mathrm{C}_{13} \mathrm{H}_{15} \mathrm{O}_{4}, 235.0970\right)$.

Higginsianin $C(\mathbf{3})$ : white amorphous solid, $[\alpha]^{25} \mathrm{D}-29\left(c\right.$ 0.1, MeOH); UV $\lambda_{\max } \mathrm{nm}(\log \varepsilon) 291$ (3.1); IR $v_{\max } 3388,2932,2893,1676,1644,1568,1383,1234,1074 \mathrm{~cm}^{-1}$; NMR data, Table 2; HRESIMS $m / z$ 445.2974 $[\mathrm{M}+\mathrm{H}]^{+}$(calcd for $\left.\mathrm{C}_{27} \mathrm{H}_{41} \mathrm{O}_{5}, 445.2954\right)$.

13-epi-higginsianin C (4): white amorphous solid, $[\alpha]^{25} \mathrm{D}-19(c 0.1, \mathrm{MeOH}) ; \mathrm{UV} \lambda_{\max } \mathrm{nm}(\log \varepsilon)$ 291 (3.1); IR $v_{\max } 3388,2932,2893,1676,1644,1568,1383,1234,1074 \mathrm{~cm}^{-1}$; NMR data, Table 2; HRESIMS $m / z$ 445.2958 $[\mathrm{M}+\mathrm{H}]^{+}$(calcd for $\left.\mathrm{C}_{27} \mathrm{H}_{41} \mathrm{O}_{5}, 445.2954\right)$.

Sclerosporide (5): transparent oil, $[\alpha]^{25} \mathrm{D}-8.3$ (c 0.1, MeOH); UV $\lambda_{\max } \mathrm{nm}(\log \varepsilon) 234$ (2.8); ECD (1 $\% \mathrm{w} / \mathrm{v}, \mathrm{MeOH}), \lambda \max (\Delta \varepsilon) 217.2(6.42) \mathrm{nm}, \mathrm{IR} v_{\max } 3396,2928,1717,1652,1379,1238,1075$, $980 \mathrm{~cm}^{-1}$; NMR data, see table 3 and supporting information; HRESIMS $m / z 425.2552[\mathrm{M}+\mathrm{H}]^{+}$ (calcd for $\mathrm{C}_{23} \mathrm{H}_{37} \mathrm{O}_{7}, 425.2539$ ).

\section{Molecular Modeling}


Three-dimensional coordinates of compounds 3, 4 and $\mathbf{5}$ were generated from SMILES using CORINA version 3.60 (Molecular Networks GmbH, http://www.molecularnetworks.com/products/corina).

The conformational analysis of these compounds was carried out using MacroModel v9.5, as implemented in the Schrödinger Suite (http://www.schrodinger.com). Default values were used except the allowed energy window $(42 \mathrm{~kJ} / \mathrm{mol})$ and the number of evaluations per rotatable bond (500). The resulting conformers were clustered using a $2.0 \AA$ cut-off.

The geometries of all conformers were optimized in gas-phase using the Gaussian 09 package (Gaussian 09, Revision D.1, Gaussian Inc., http://www.gaussian.com) ${ }^{46}$ with the Becke's threeparameter hybrid exchange functional (B3LYP); ${ }^{47-48}$ and the $6-31+\mathrm{G}(\mathrm{d}, \mathrm{p})$ basis set. Subsequent vibrational frequency calculations confirmed that these conformations were local minima.

NMR chemical shifts and coupling constants were calculated at the B3LYP/6-31+G(d,p) level following the protocol described by Tantillo and colleagues at the CHESHIRE Chemical Shift Repository (http://cheshirenmr.info//49 using the Gaussian09 package. The analysis of results was performed using an in-house-developed script.

ECD spectra were computed at the B3LYP/TZVP level (60 excited states), using Gaussian09. ${ }^{46}$ The computed and experimental ECD spectra were superimposed using SpecDis. ${ }^{50}$

Structure images were obtained with Chimera $^{51}$ using the Pov-Ray rendering feature.

\section{ASSOCIATED CONTENT.}

Supporting Information. The Supporting Information is available free of charge on the ACS Publications website at DOI:”..

\section{AUTHOR INFORMATION.}

Corresponding Author 
*Tel: +3316982 30 01. Fax: +33 1690772 47. E-mail: jamal.ouazzani@,cnrs.fr

\section{ACKNOWLEDGMENT.}

R.J.O. received funding from the French National Research Agency (grant ANR-12-CHEX-0008-

01)

\section{REFERENCES AND NOTES}

\section{REFERENCES AND NOTES}

(1) O'Connell, R.; Herbert, C.; Sreenivasaprasad, S.; Khatib, M.; Esquerre-Tugaye, M. T.; Dumas, B. Mol Plant Microbe Interact 2004, 17, 272-82.

(2) Birker, D.; Heidrich, K.; Takahara, H.; Narusaka, M.; Deslandes, L.; Narusaka, Y.; Reymond, M.; Parker, J. E.; O'Connell, R. Plant J 2009, 60, 602-13.

(3) Dallery, J.-F.; Lapalu, N.; Zampounis, A.; Pigné, S.; Luyten, I.; Amselem, J.; Wittenberg, A. H. J.; Zhou, S.; de Queiroz, M. V.; Robin, G. P.; Auger, A.; Hainaut, M.; Henrissat, B.; Kim, K.-T.; Lee, Y.-H.; Lespinet, O.; Schwartz, D. C.; Thon, M. R.; O’Connell, R. J. BMC Genomics 2017, 18, 667.

(4) Giles, S. S.; Soukup, A. A.; Lauer, C.; Shaaban, M.; Lin, A.; Oakley, B. R.; Wang, C. C. C.; Keller, N. P. Appl. Environ. Microbiol. 2011, 77, 3669-3675.

(5) Bok, J. W.; Chiang, Y. M.; Szewczyk, E.; Reyes-Dominguez, Y.; Davidson, A. D.; Sanchez, J. F.; Lo, H. C.; Watanabe, K.; Strauss, J.; Oakley, B. R.; Wang, C. C.; Keller, N. P. Nat Chem Biol 2009, 5, 462-4.

(6) Reyes-Dominguez, Y.; Boedi, S.; Sulyok, M.; Wiesenberger, G.; Stoppacher, N.; Krska, R.; Strauss, J. Fungal Genet Biol 2012, 49, 39-47.

(7) Chujo, T.; Scott, B. Mol Microbiol 2014, 92, 413-34.

(8) Wu, G.; Zhou, H.; Zhang, P.; Wang, X.; Li, W.; Zhang, W.; Liu, X.; Liu, H.-W.; Keller, N. P.; An, Z.; Yin, W.-B. Org. Lett. 2016, 18, 1832-1835. 
(9) Miller, T.; Krogan, N. J.; Dover, J.; Erdjument-Bromage, H.; Tempst, P.; Johnston, M.; Greenblatt, J. F.; Shilatifard, A. Proc. Natl. Acad. Sci. U.S.A. 2001, 98, 12902-12907.

(10) Palmer, J. M.; Bok, J. W.; Lee, S.; Dagenais, T. R.; Andes, D. R.; Kontoyiannis, D. P.; Keller, N. P. PeerJ 2013, 1, e4.

(11) Kosuge, Y.; Suzuki, A.; Hirata, S.; Tamura, S. Agric. Biol. Chem. 1973, 37, 455-456.

(12) Kosuge, Y.; Suzuki, A.; Tamura, S. Agric. Biol. Chem. 1974, 38, 1265-1267.

(13) Kosuge, Y.; Suzuki, A.; Tamura, S. Agric. Biol. Chem. 1974, 38, 1553-1554.

(14) Cimmino, A.; Mathieu, V.; Masi, M.; Baroncelli, R.; Boari, A.; Pescitelli, G.; Ferderin, M.; Lisy, R.; Evidente, M.; Tuzi, A.; Zonno, M. C.; Kornienko, A.; Kiss, R.; Evidente, A. J. Nat. Prod. 2016, 79, 116-125.

(15) Masi, M.; Cimmino, A.; Boari, A.; Tuzi, A.; Zonno, M. C.; Baroncelli, R.; Vurro, M.; Evidente, A. J Agric Food Chem 2017, 65, 1124-1130.

(16) Le Goff, G.; Adelin, E.; Cortial, S.; Servy, C.; Ouazzani, J. Bioprocess Biosyst. Eng. 2013, $36,1285-1290$.

(17) Le Goff, G.; Martin, M.-T.; Iorga, B. I.; Adelin, E.; Servy, C.; Cortial, S.; Ouazzani, J. J. Nat. Prod. 2013, 76, 142-149.

(18) Kawagishi, H.; Sato, H.; Sakamura, S.; Kobayashi, K.; Tadao, U. Agric. Biol. Chem. 1984, 48, 1903-1904.

(19) Masi, M.; Zonno, M. C.; Cimmino, A.; Reveglia, P.; Berestetskiy, A.; Boari, A.; Vurro, M.; Evidente, A. Nat. Prod. Res. 2017, 32, 1537-1547.

(20) Masi, M.; Cimmino, A.; Boari, A.; Zonno, M. C.; Górecki, M.; Pescitelli, G.; Tuzi, A.; Vurro, M.; Evidente, A. Tetrahedron 2017, 73, 6644-6650.

(21) Fujii, I.; Mori, Y.; Watanabe, A.; Kubo, Y.; Tsuji, G.; Ebizuka, Y. Biosci. Biotechnol. Biochem. 1999, 63, 1445-1452.

(22) Nawata, Y.; Ando, K.; Tamura, G.; Arima, K.; Iitaka, Y. J Antibiot (Tokyo) 1969, 22, 511-2. 
(23) Tamura, G.; Suzuki, S.; Takatsuki, A.; Ando, K.; Arima, K. J Antibiot (Tokyo) 1968, 21, $539-44$

(24) Cagnoli-Bellavita, N.; Ceccherelli, P.; Fringuelli, R.; Ribaldi, M. Phytochemistry 1975, 14, 807.

(25) Singh, S. B.; Zink, D. L.; Bills, G. F.; Jenkins, R. G.; Silverman, K. C.; Lingham, R. B. Tetrahedron Lett. 1995, 36, 4935-4938.

(26) Sasaki, H.; Okutomi, T.; Hosokawa, T.; Nawata, Y.; Ando, K. Tetrahedron Lett. 1972, 13, 2541-2544.

(27) Gutiérrez, M.; Theoduloz, C.; Rodríguez, J.; Lolas, M.; Schmeda-Hirschmann, G. J. Agric. Food Chem. 2005, 53, 7701-7708.

(28) Singh, S. B.; Zink, D. L.; Dombrowski, A. W.; Dezeny, G.; Bills, G. F.; Felix, J. P.; Slaughter, R. S.; Goetz, M. A. Org. Lett. 2001, 3, 247-250.

(29) Nothias-Scaglia, L. F.; Gallard, J. F.; Dumontet, V.; Roussi, F.; Costa, J.; Iorga, B. I.; Paolini, J.; Litaudon, M. J Nat Prod 2015, 78, 2423-31.

(30) Katayama, M.; Marumo, S.; Hattori, H. Tetrahedron Lett. 1983, 24, 1703-1706.

(31) Katayama, M.; Marumo, S. Agric. Biol. Chem. 1978, 42, 505-506.

(32) Harada, Y.; Sawamura, K.; Konno, K. J. J. Phytopath. 1974, 40, 412-418.

(33) Sawai, K.; Okuno, T.; Yoshikawa, E. Agric. Biol. Chem. 1985, 49, 2501-2503.

(34) Almeida, C.; Eguereva, E.; Kehraus, S.; Siering, C.; König, G. M. J. Nat. Prod. 2010, 73, 476-478.

(35) Kitahara, T.; Kurata, H.; Matsuoka, T.; Mori, K. Tetrahedron 1985, 41, 5475-5485.

(36) Okada, K.; Koseki, K.; Kitahara, T.; Mori, K. Agric. Biol. Chem. 1985, 49, 487-493.

(37) Kitahara, T.; Matsuoka, T.; Katayama, M.; Marumo, S.; Mori, K. Tetrahedron Lett. 1984, $25,4685-4688$.

(38) Gallagher, R. T. Phytochemistry 1975, 14, 755-757. 
(39) Shakeel, U. R.; Sofi, S. N.; Khuroo, M. A.; Taneja, S. C.; Bhat, K. A.; Vishwakarma, R. Nat Prod Res 2013, 27, 2033-8.

(40) Sureshan, K. M.; Murakami, T.; Watanabe, Y. Tetrahedron 2009, 65, 3998-4006.

(41) De Almeida, M. V.; Couri, M. R. C.; De Assis, J. V.; Anconi, C. P. A.; Dos Santos, H. F.; De Almeida, W. B. Magn. Reson. Chem. 2012, 50, 608-614.

(42) Newton, G. L.; Fahey, R. C. Arch. Microbiol. 2002, 178, 388-394.

(43) Mo, E.; Ahn, J.; Jo, Y.; Kim, S.; Hwang, B.; Lee, M. Molecules 2017, 22, 1349.

(44) Wu, T.; Liang, Y.; Zhu, X.; Zhao, M.; Liu, H. Anal. Bioanal. Chem. 2014, 406, 3239-3247.

(45) Wu, J.; Tang, C.; Yao, S.; Zhang, L.; Ke, C.; Feng, L.; Lin, G.; Ye, Y. J. Nat. Prod. 2015, $78,2332-2338$.

(46) Frisch, M. J.; Trucks, G. W.; Schlegel, H. B.; Scuseria, G. E.; Robb, M. A.; Cheeseman, J. R.; Scalmani, G.; Barone, V.; Mennucci, B.; Petersson, G. A.; et al. Gaussian 09, Revision D.01. Gaussian Inc.: Wallingford CT, USA (http://www.gaussian.com).

(47) Lee, C.; Yang, W.; Parr, R. G. Phys. Rev. B 1988, 37, 785-789.

(48) Becke, A. D. J. Chem. Phys. 1993, 98, 5648-5652.

(49) Lodewyk, M. W.; Siebert, M. R.; Tantillo, D. J. Chem Rev 2012, 112, 1839-62.

(50) Bruhn, T.; Schaumlöffel, A.; Hemberger, Y.; Bringmann, G. Chirality 2013, 25, 243-249.

(51) Pettersen, E. F.; Goddard, T. D.; Huang, C. C.; Couch, G. S.; Greenblatt, D. M.; Meng, E. C.; Ferrin, T. E. J Comput Chem 2004, 25, 1605-12. 
For Table of Contents Only (Graphical Abstract)
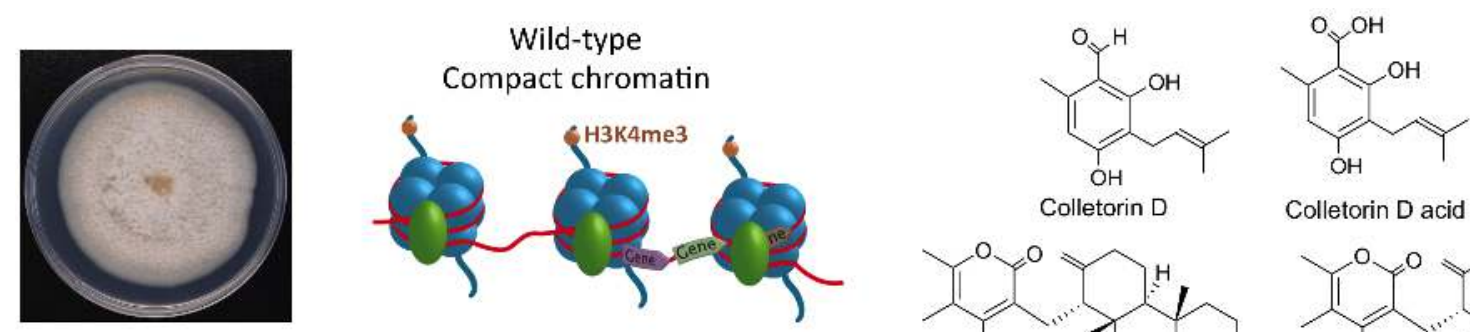

Colletorin D acid
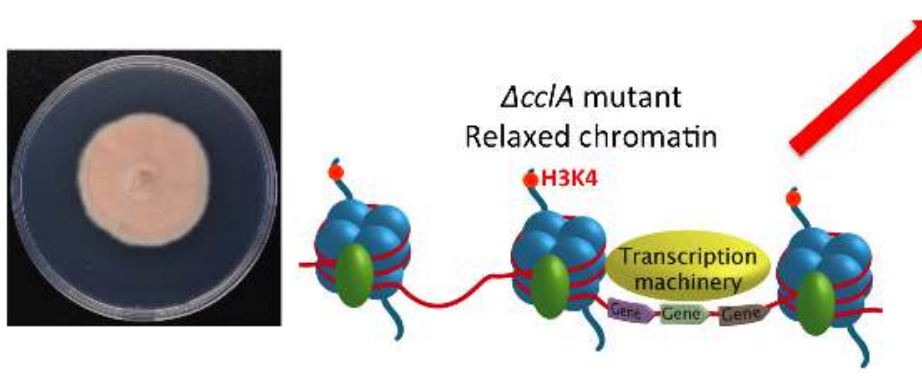

Higginsianin C
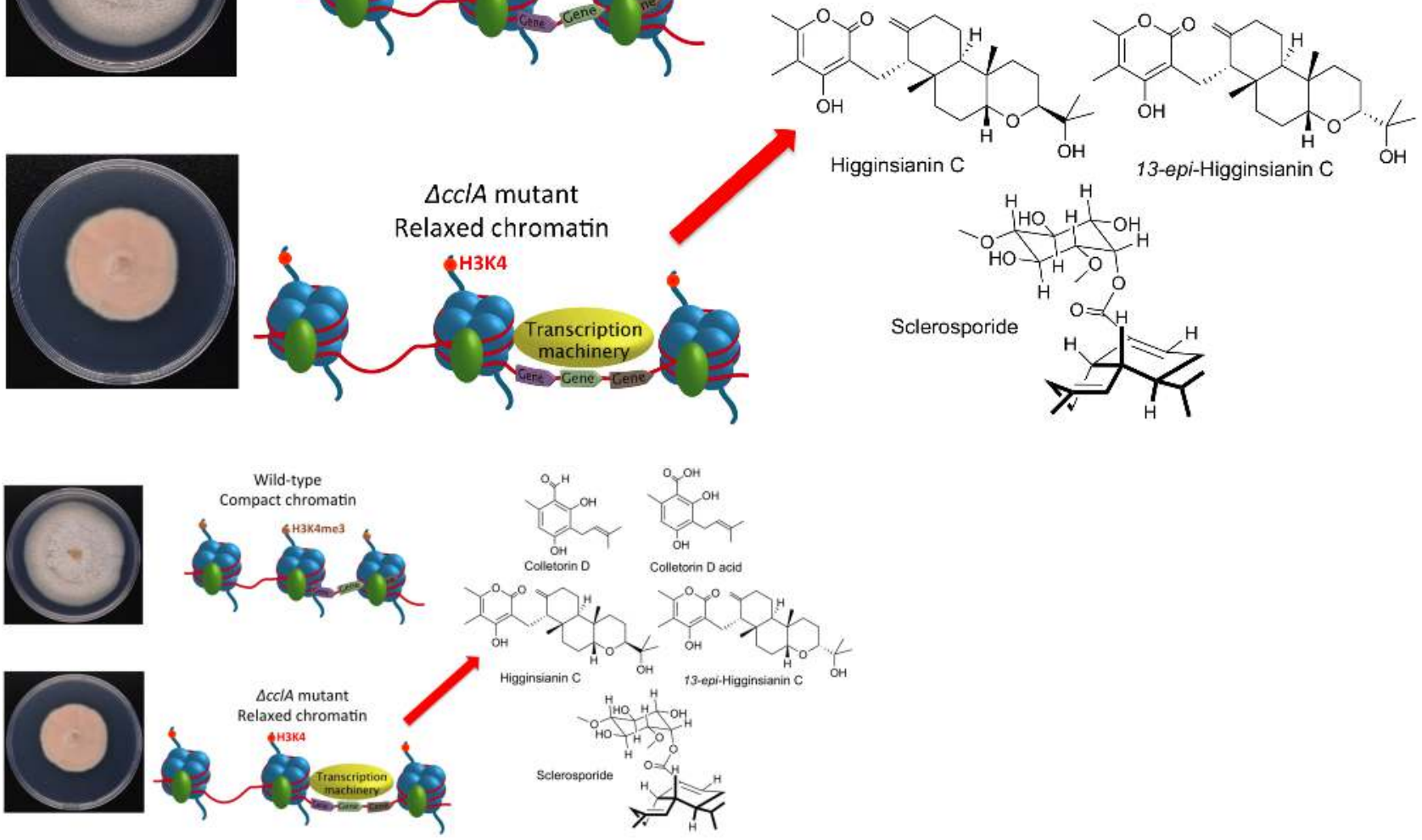


\section{Supporting Information}

Deleting a chromatin remodeling gene increases the diversity of secondary metabolites produced by Colletotrichum higginsianum

Jean-Félix Dallery, ${ }^{\dagger}$ Géraldine Le Goff, ${ }^{\dagger}$ Emilie Adelin,${ }^{\dagger}$ Bogdan I. Iorga,${ }^{\dagger}$ Sandrine Pigné,$\ddagger$

Richard O'Connell, $\ddagger$ Jamal Ouazzani ${ }^{\dagger *}$

$\dagger$ Centre National de la Recherche Scientifique, Institut de Chimie des Substances Naturelles ICSN, Avenue de la Terrasse 91198, Gif-surYvette, cedex, France.

¥UMR BIOGER, INRA, AgroParisTech, Université Paris-Saclay, Avenue Lucien Brétignières, 78850, Thiverval-Grignon, France. 


\section{TABLE OF CONTENT}

S1. 1H NMR spectrum of colletochlorin D (CDCl3, $500 \mathrm{MHz})$.

S2. 13C NMR spectrum of colletochlorin $\mathrm{D}(\mathrm{CDCl} 3,125 \mathrm{MHz})$.

S3. $1 \mathrm{H}-1 \mathrm{H}$ COSY spectrum of colletochlorin $\mathrm{D}(\mathrm{CDCl} 3,500 \mathrm{MHz})$.

S4. 1H-13C HSQC-ED spectrum of colletochlorin D (CDCl3, $500 \mathrm{MHz})$.

S5. 1H-13C HMBC spectrum of colletochlorin D (CDCl3, $500 \mathrm{MHz})$.

S6. 1H NMR spectrum of colletorin D (1) (CDC13, $500 \mathrm{MHz})$.

S7. 13C NMR spectrum of colletorin D (1) (CDCl3, $125 \mathrm{MHz})$.

S8. $1 \mathrm{H}-1 \mathrm{H}$ COSY spectrum of colletorin D (1) $(\mathrm{CDCl} 3,500 \mathrm{MHz})$.

S9. 1H-13C HSQC-ED spectrum of colletorin D (1) (CDCl3, $500 \mathrm{MHz})$.

S10. 1H-13C HMBC spectrum of colletorin D (1) (CDCl3, $500 \mathrm{MHz})$.

S11. HRESIMS of colletorin D (1)

S12. 1H NMR spectrum of colletorin D acid (2) (CD3OD, $500 \mathrm{MHz})$.

S13. 13C NMR spectrum of colletorin D acid (2) (CD3OD, $125 \mathrm{MHz}$ ).

S14. $1 \mathrm{H}-1 \mathrm{H}$ COSY spectrum of colletorin D acid (2) (CD3OD, $500 \mathrm{MHz}$ ).

S15. 1H-13C HSQC-ED spectrum of colletorin D acid (2) (CD3OD, $500 \mathrm{MHz}$ ).

S16. 1H-13C HMBC spectrum of colletorin D acid (2) (CD3OD, $500 \mathrm{MHz}$ ).

S17. HRESIMS of colletorin D acid (2)

S18. 1H NMR spectrum of Higginsianin C (3) (CD3OD, $500 \mathrm{MHz})$.

S19. 13C NMR spectrum of Higginsianin C (3) (CD3OD, $125 \mathrm{MHz})$.

S20. $1 \mathrm{H}-1 \mathrm{H}$ COSY spectrum of Higginsianin C (3) (CD3OD, $500 \mathrm{MHz})$.

S21. 1H-13C HSQC-ED spectrum of Higginsianin C (3) (CD3OD, $500 \mathrm{MHz}$ ).

S22. $1 \mathrm{H}-13 \mathrm{C}$ HMBC spectrum of Higginsianin C (3) (CD3OD, $500 \mathrm{MHz}$ ).

S23. 1H-1H ROESY spectrum of Higginsianin C (3) (CD3OD, $500 \mathrm{MHz}$ ).

S24. HRESIMS of Higginsianin C (3)

S25. IR spectrum of Higginsianin C (3)

S26. 1H NMR spectrum of 13-epi-higginsianin C (4) (CD3OD, $500 \mathrm{MHz}$ ).

S27. 13C NMR spectrum of 13-epi-higginsianin C (4) (CD3OD, $125 \mathrm{MHz}$ ).

S28. 1H-1H COSY spectrum of 13-epi-higginsianin C (4) (CD3OD, $500 \mathrm{MHz}$ ).

S29. 1H-13C HSQC-ED spectrum of 13-epi-higginsianin C (4) (CD3OD, 500

$\mathrm{MHz})$.

S30. 1H-13C HMBC spectrum of 13-epi-higginsianin C (4) (CD3OD, $500 \mathrm{MHz}$ ).

S23. $1 \mathrm{H}-1 \mathrm{H}$ ROESY spectrum of 13-epi-higginsianin C (4) (CD3OD, $500 \mathrm{MHz}$ ).
S31. HRESIMS of 13-epi-higginsianin C (4)

S32. IR spectrum of 13-epi-higginsianin C (4)

S33. 1H NMR spectrum of sclerosporide (5) (CD3OD, $500 \mathrm{MHz})$.

S34. 13C NMR spectrum of sclerosporide (5) (CD3OD, $125 \mathrm{MHz})$.

S35. $1 \mathrm{H}-1 \mathrm{H}$ COSY spectrum of sclerosporide (5) (CD3OD, $500 \mathrm{MHz})$.

S36. 1H-13C HSQC-ED spectrum of sclerosporide (5) (CD3OD, $500 \mathrm{MHz}$ ).

S37. 1H-13C HMBC spectrum of sclerosporide (5) (CD3OD, $500 \mathrm{MHz}$ ).

S38. 1H-1H ROESY spectrum of sclerosporide (5) (CD3OD, $500 \mathrm{MHz}$ ).

S39. HRESIMS of sclerosporide (5)

S40. IR spectrum of sclerosporide (5)

S41. Comparison of ${ }^{1} \mathrm{H}$ NMR Data from Experimental Chemical Shifts $\left(\delta_{\text {exp }}\right)$ vs Calculated Chemical Shifts by DFT-NMR $\left(\delta_{\text {calcd }}\right)$ for compounds 3 and $\mathbf{4}\left(\delta_{\mathrm{H}}\right.$ in ppm)

S42. Comparison of ${ }^{13} \mathrm{C}$ NMR Data from Experimental Chemical Shifts $\left(\delta_{\text {exp }}\right)$ vs Calculated Chemical Shifts by DFT-NMR $\left(\delta_{\text {calcd }}\right)$ for compounds 3 and $\mathbf{4}\left(\delta_{\mathrm{H}}\right.$ in ppm)

S43. Comparison of ${ }^{1} \mathrm{H}$ NMR Data from Experimental Chemical Shifts $\left(\delta_{\text {exp }}\right)$ vs Calculated Chemical Shifts by DFT-NMR $\left(\delta_{\text {calcd }}\right)$ for compound 5 ( $\delta_{\mathrm{H}}$ in ppm)

S44. Comparison of ${ }^{13} \mathrm{C}$ NMR Data from Experimental Chemical Shifts $\left(\delta_{\text {exp }}\right)$ vs Calculated Chemical Shifts by DFT-NMR $\left(\delta_{\text {calcd }}\right)$ for compound 5 ( $\delta_{\mathrm{H}}$ in ppm)

From page 48 to page 54, Energy, Coordinates and Frequencies for compounds 3,4 and 5 .

From page 55 to 57, 3D dynamic structures of compounds 3, 4 and 5 .

S45. Experimental data for known compounds isolated in this study.

S46. Superposed experimental ECD spectrum (black) with the ECD computed spectrum (red) for compounds 3 (left) and 4 (right). 
(c)

Colletochlorin D

$\frac{8}{\frac{8}{0}}$
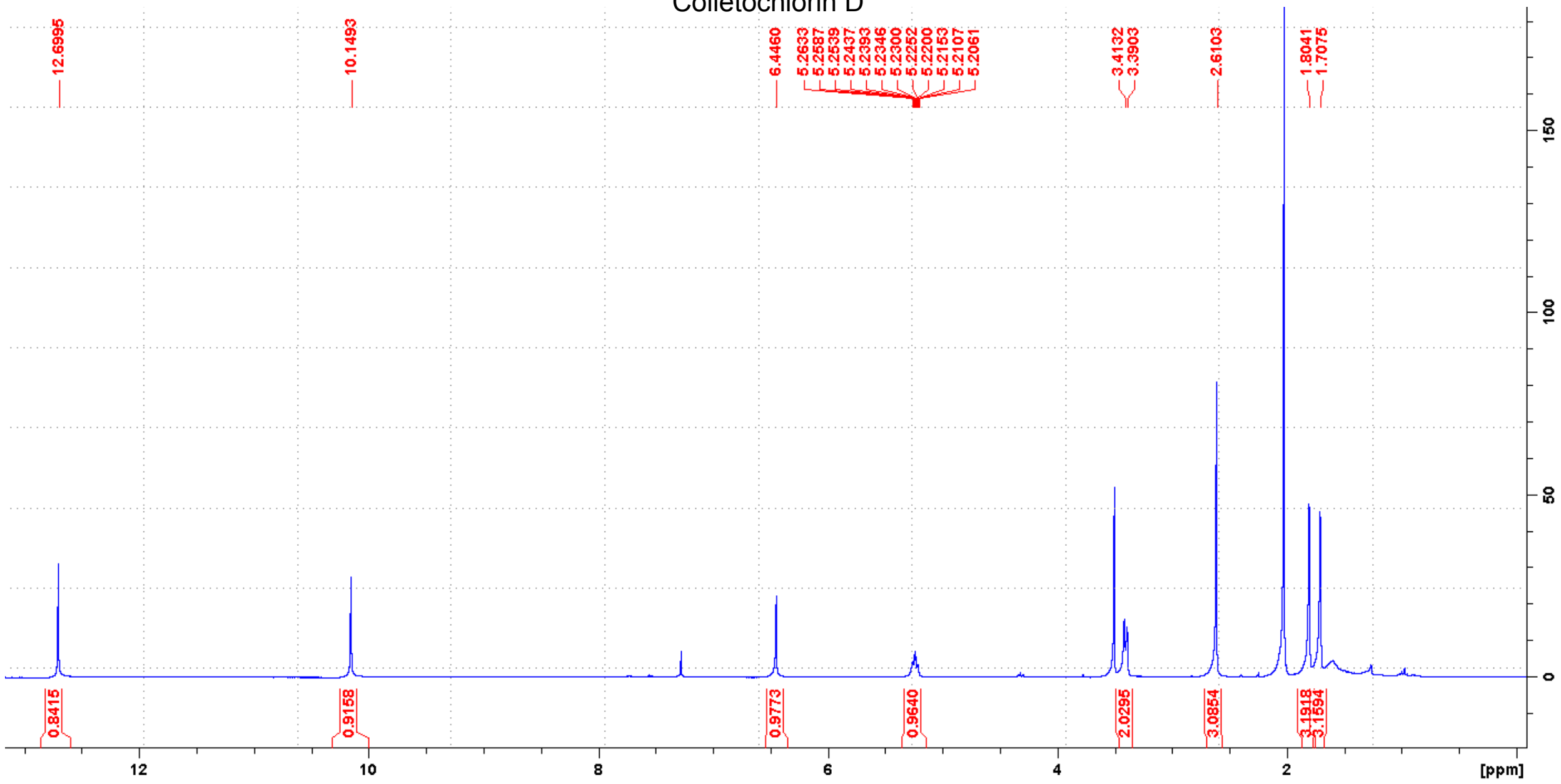

S1. ${ }^{1} \mathrm{H}$ NMR spectrum of colletochlorin $\mathrm{D}\left(\mathrm{CDCl}_{3}, 500 \mathrm{MHz}\right)$. 


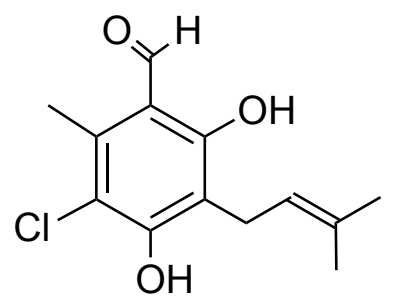

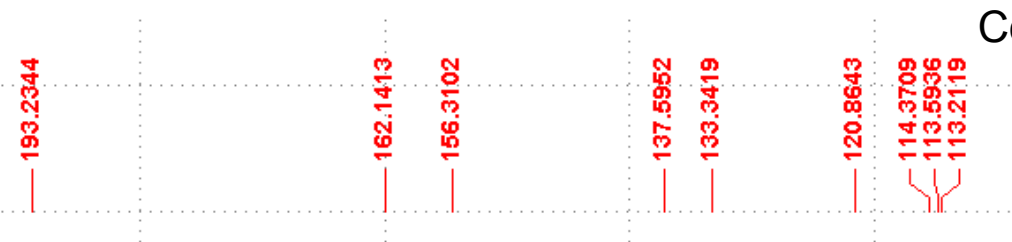

Colletochlorin D

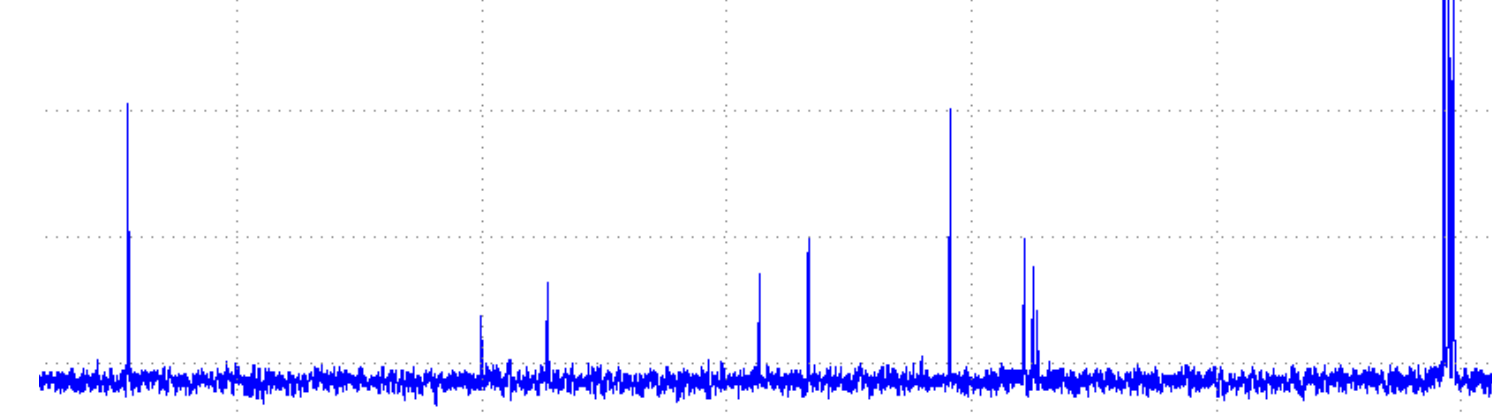

S2. ${ }^{13} \mathrm{C}$ NMR spectrum of colletochlorin $\mathrm{D}\left(\mathrm{CDCl}_{3}, 125 \mathrm{MHz}\right)$. 


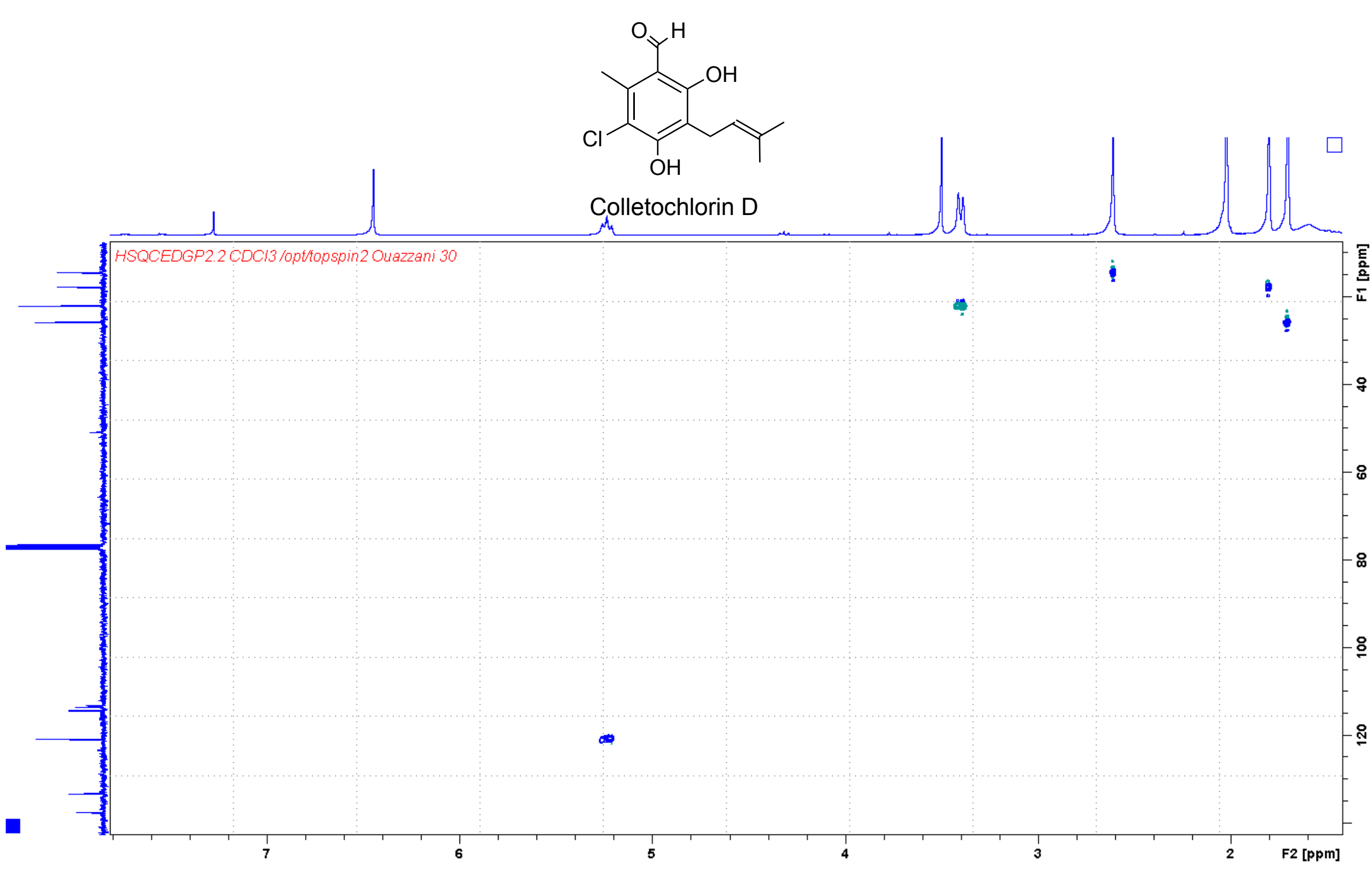

S4. ${ }^{1} \mathrm{H}-{ }^{13} \mathrm{C}$ HSQC-ED spectrum of colletochlorin $\mathrm{D}\left(\mathrm{CDCl}_{3}, 500 \mathrm{MHz}\right)$. 

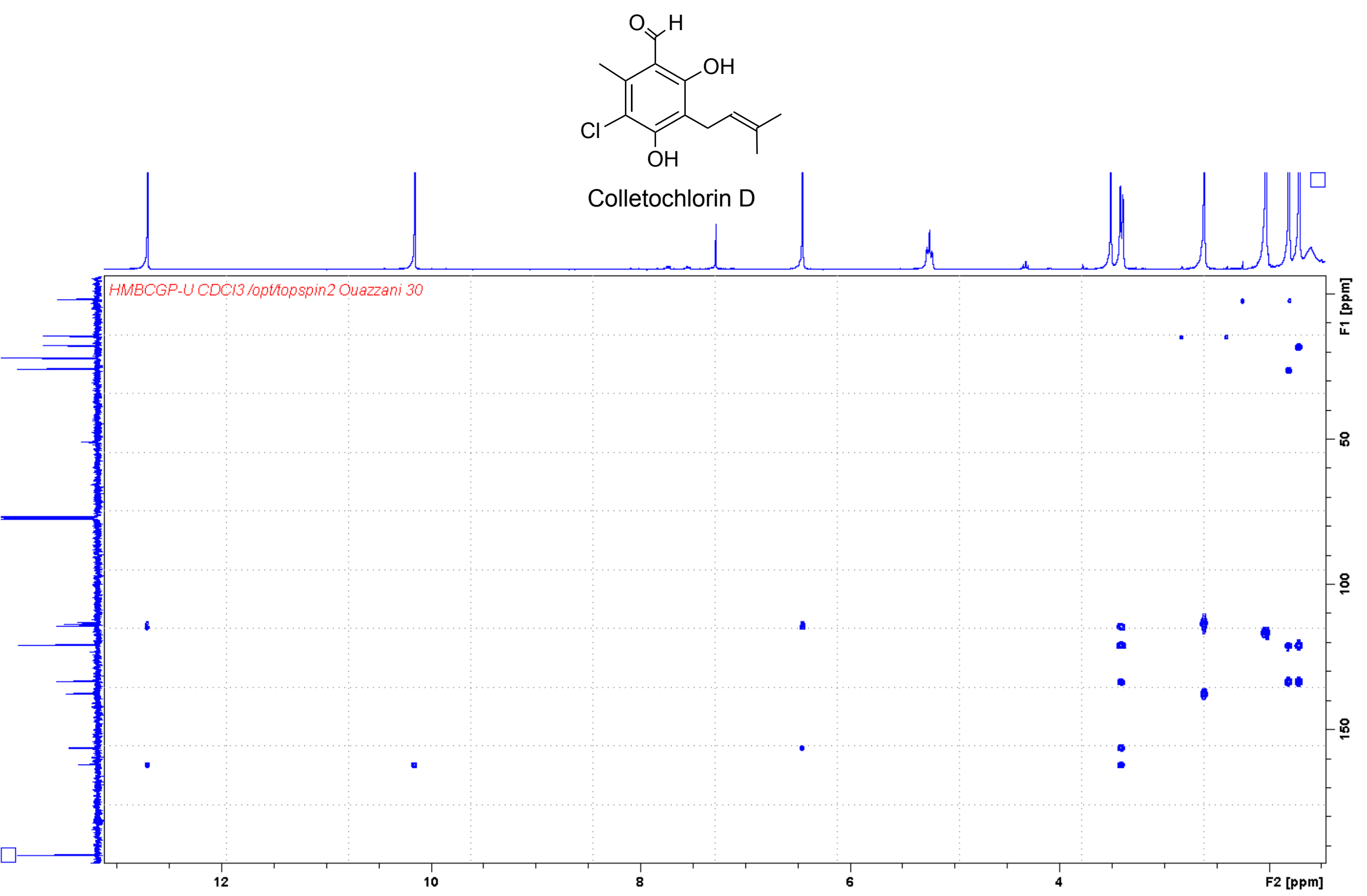

S5. ${ }^{1} \mathrm{H}-{ }^{13} \mathrm{C}$ HMBC spectrum of colletochlorin $\mathrm{D}\left(\mathrm{CDCl}_{3}, 500 \mathrm{MHz}\right)$. 

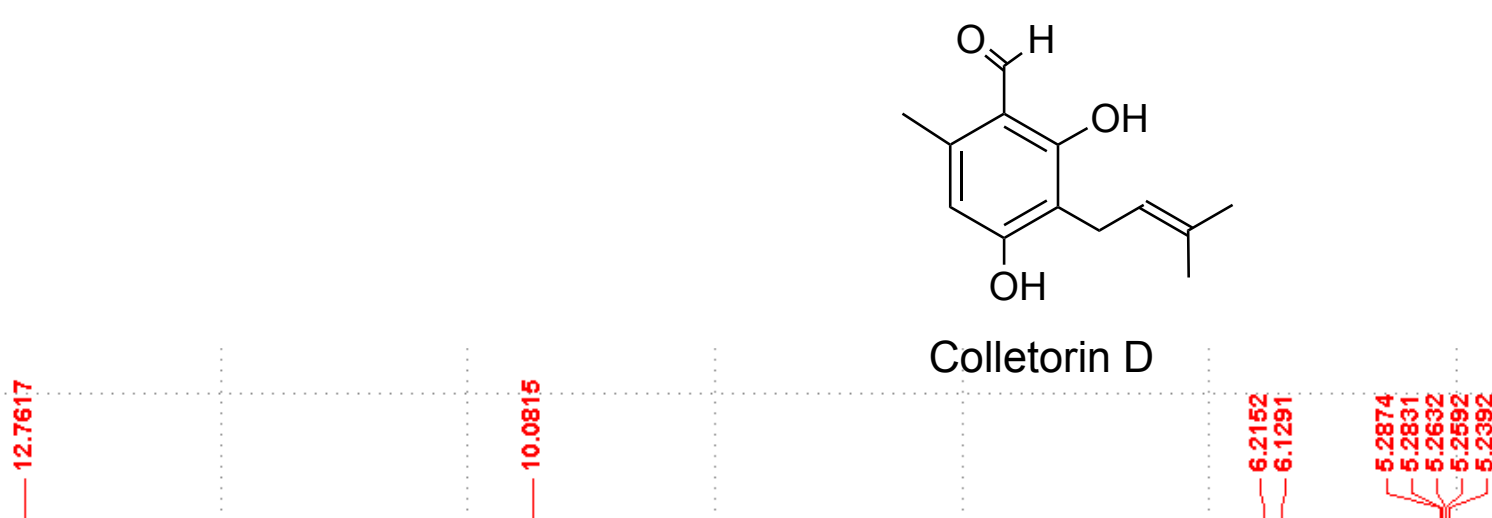

S6. ${ }^{1} \mathrm{H}$ NMR spectrum of colletorin D (1) $\left(\mathrm{CDCl}_{3}, 500 \mathrm{MHz}\right)$. 

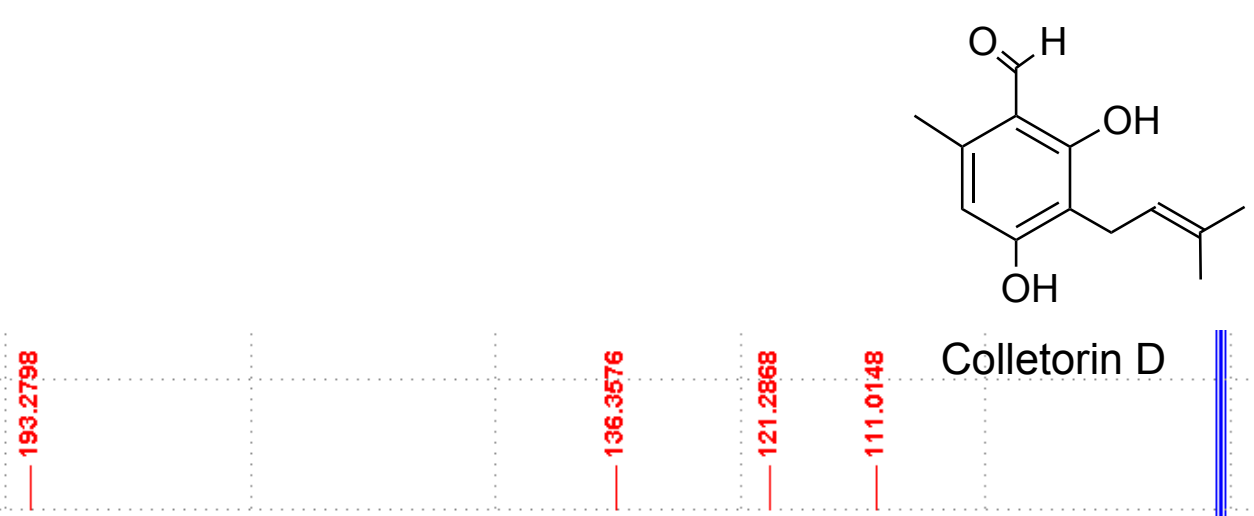

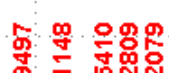

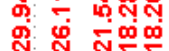

111

,

\section{i}




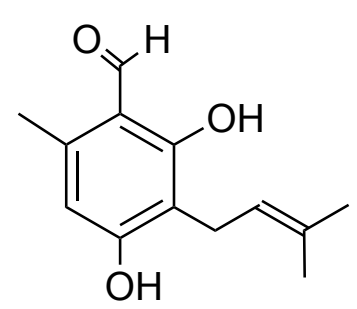

\section{Colletorin D}

\section{Elemental Composition Report}

Page 1

\section{Single Mass Analysis}

Tolerance $=10.0$ PPM / DBE: $\min =-1.5, \max =100.0$

Element prediction: Off

Number of isotope peaks used for $\mathrm{i}-\mathrm{FIT}=9$

Monoisotopic Mass, Even Electron lons

247 formula(e) evaluated with 1 results within limits (all results (up to 1000) for each mass)

Elements Used:

$\begin{array}{llll}\text { C: } 0-50 & \text { H: } 0-100 & \text { N: } 0-10 & \text { O: } 0-10\end{array}$

OUAZZANI_adelin53-1 $22(0.588) \mathrm{Cm}(16: 28-41: 64 \times 2.000)$

1: TOF MS ES+ $2.24 \mathrm{e}+004$

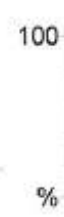

S11. HRESIMS of colletorin D (1) 


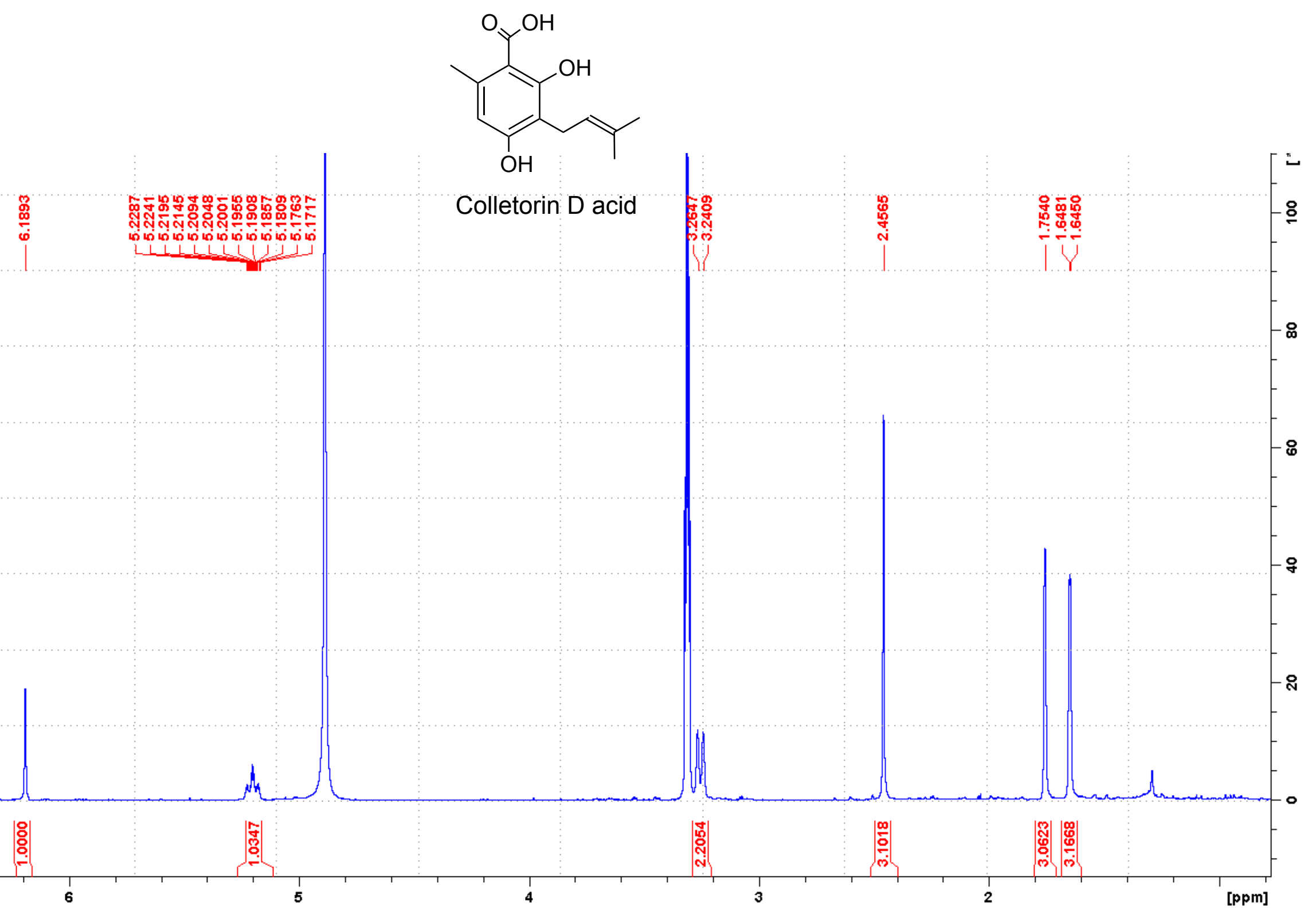

S12. ${ }^{1} \mathrm{H}$ NMR spectrum of colletorin $\mathrm{D}$ acid (2) $\left(\mathrm{CD}_{3} \mathrm{OD}, 500 \mathrm{MHz}\right)$.

Difficult to solubilize in chloroform (Exchangeable aldehyde and hydroxyl protons not seen in the spectrum) 


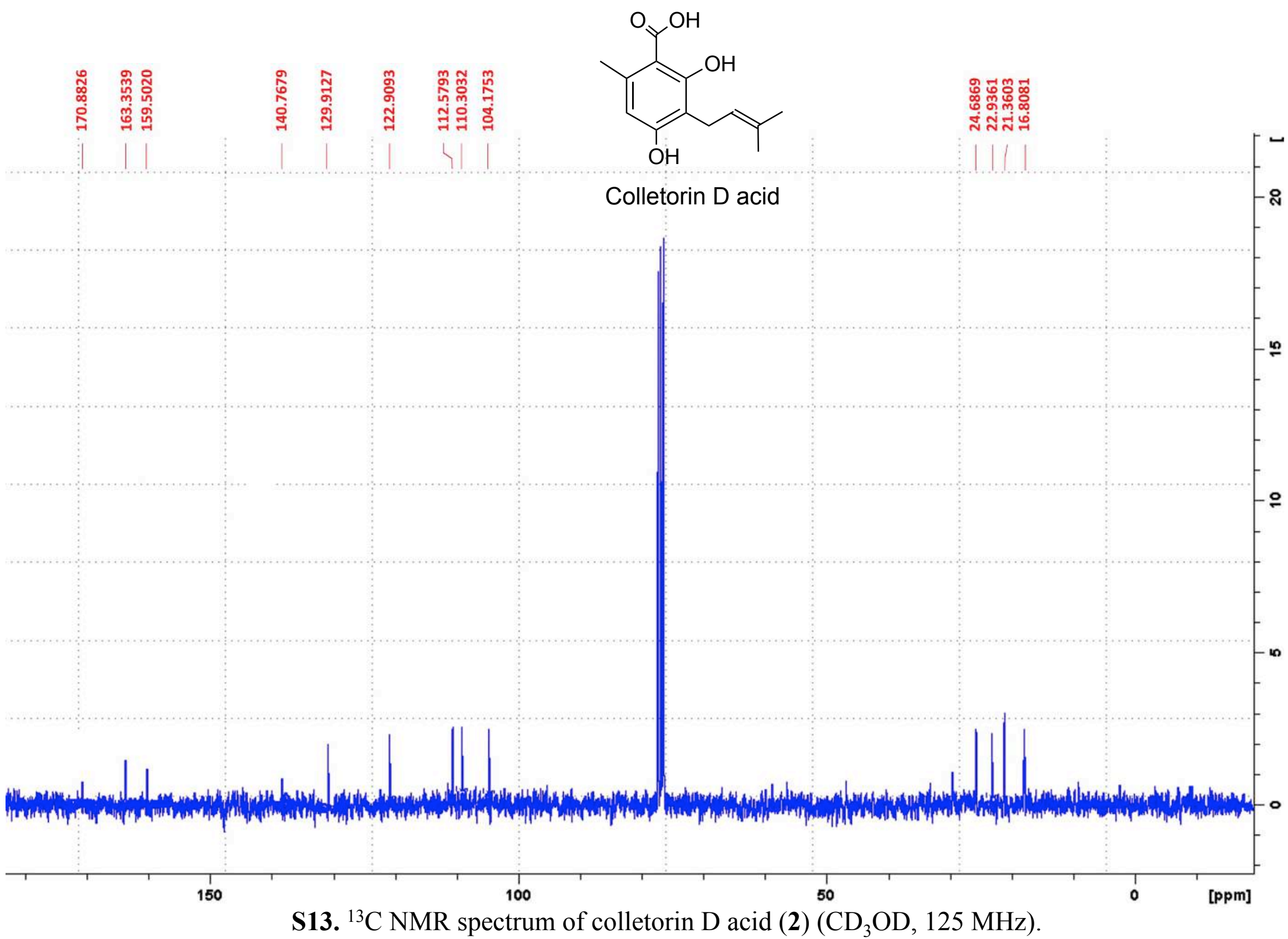




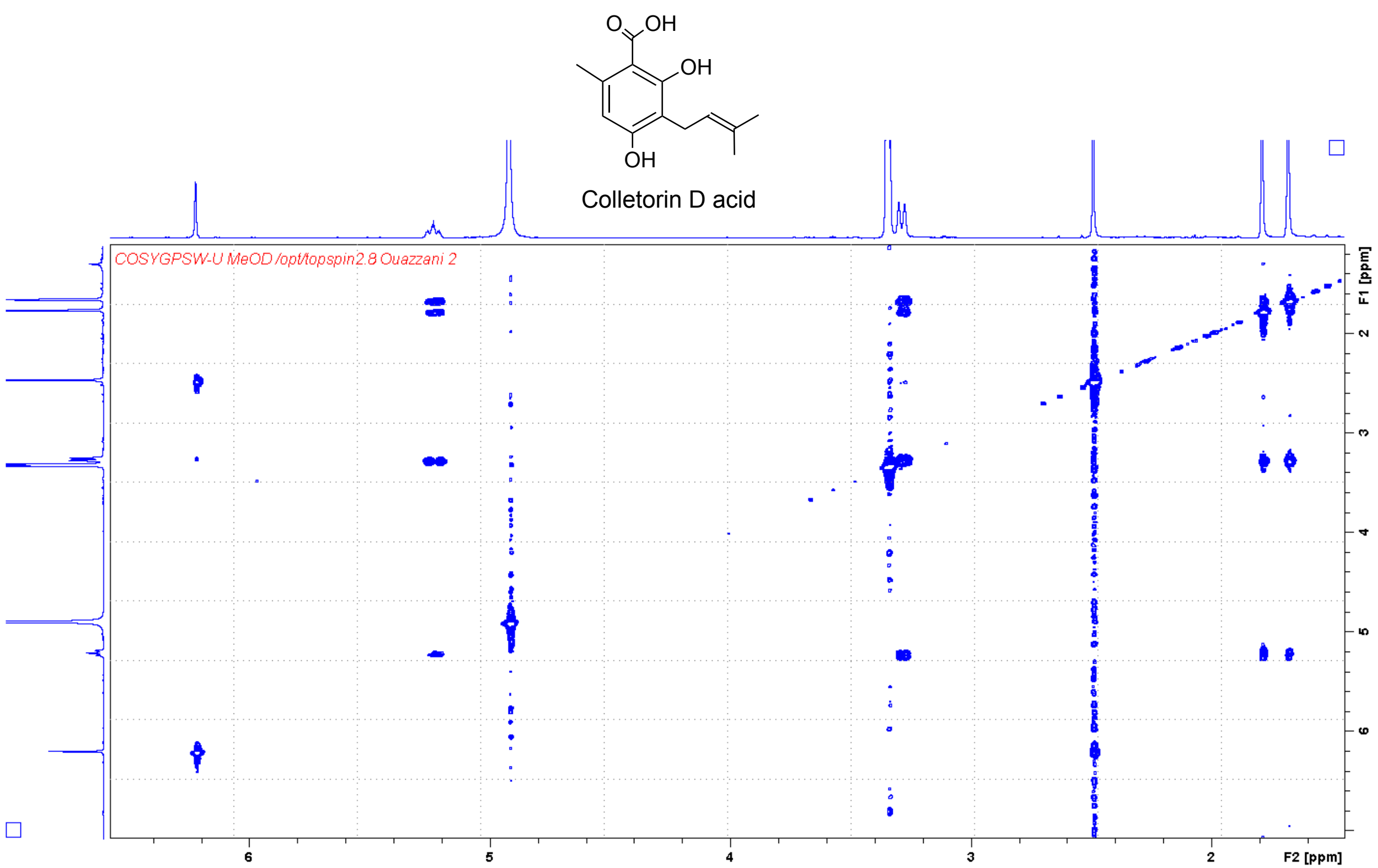

S14. ${ }^{1} \mathrm{H}-{ }^{1} \mathrm{H}$ COSY spectrum of colletorin D acid (2) $\left(\mathrm{CD}_{3} \mathrm{OD}, 500 \mathrm{MHz}\right)$. 


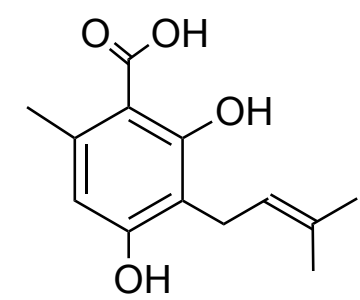

\section{Colletorin D acid}

\section{Elemental Composition Report}

\section{Single Mass Analysis}

Tolerance $=10.0$ PPM / DBE: $\min =-1.5, \max =100.0$

Element prediction: Off

Number of isotope peaks used for i-FIT $=9$

Monoisotopic Mass, Even Electron lons

278 formula(e) evaluated with 2 results within limits (all results (up to 1000) for each mass)

Elements Used:

$\begin{array}{llll}\text { C: } 0-50 \quad \mathrm{H}: 0-100 \quad \mathrm{~N}: 0-10 & 0: 0-10\end{array}$

OUAZZANLadelin54-1 22 (0.591) $\mathrm{Cm}(17: 28-36: 59 \times 2.000)$

$100 \quad 237.1130$

$3.63 e+004$

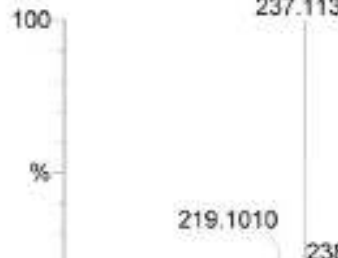

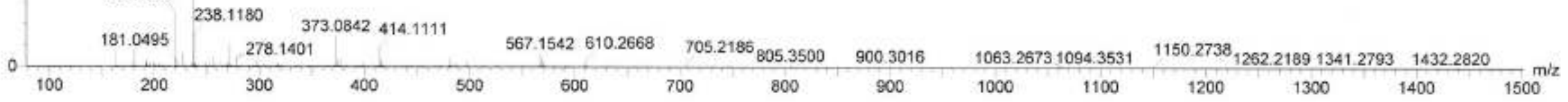

\begin{tabular}{|c|c|c|c|c|c|c|c|c|c|}
\hline $\begin{array}{l}\text { Minimum: } \\
\text { Masimum: }\end{array}$ & & 5.0 & 10.0 & -1.5 & & & & & \\
\hline Mass & Calc. Mass & $\mathrm{mDa}$ & PPM & DBE & i-FIT & I-FIT & (Norm) & Formula & \\
\hline 233.1130 & $\begin{array}{l}237.1127 \\
237.1140\end{array}$ & $\begin{array}{l}0,3 \\
-1.0\end{array}$ & $\begin{array}{l}1.3 \\
-4.2\end{array}$ & $\begin{array}{l}5.5 \\
10.5\end{array}$ & $\begin{array}{l}581.6 \\
586.3\end{array}$ & $\begin{array}{l}0.0 \\
4.7\end{array}$ & & $\begin{array}{ll}\mathrm{C} 13 & \mathrm{H} 17 \\
\mathrm{C} 14 & \mathrm{H} 13\end{array}$ & $\begin{array}{l}\mathrm{O} 4 \\
\mathrm{~N} 4\end{array}$ \\
\hline
\end{tabular}

S17. HRESIMS of colletorin D acid (2) 

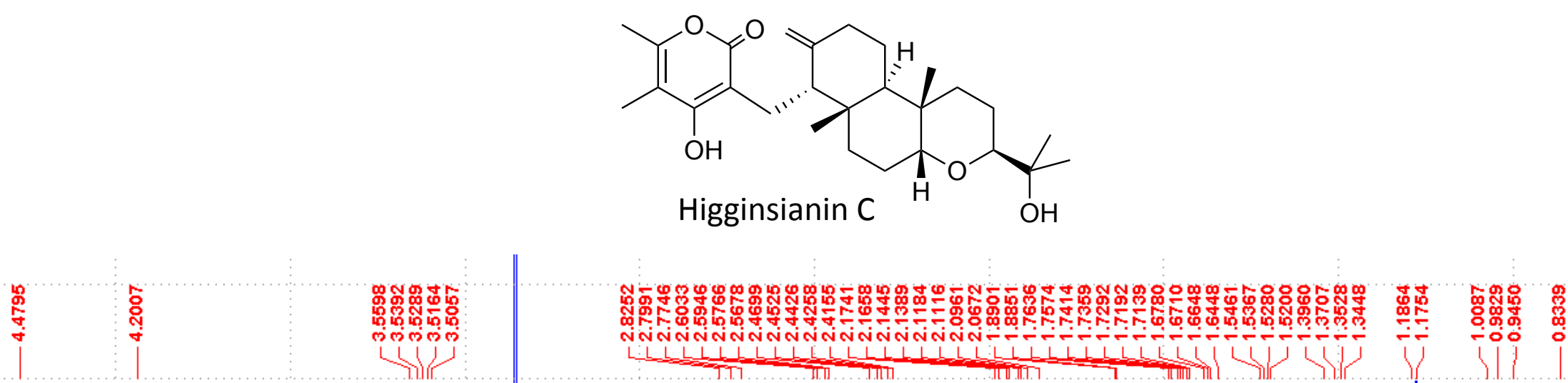

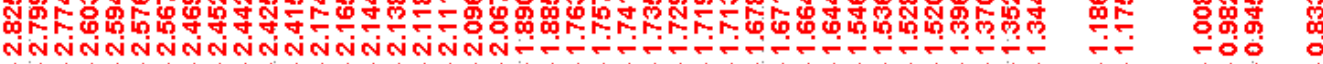

IITTा $7=2$
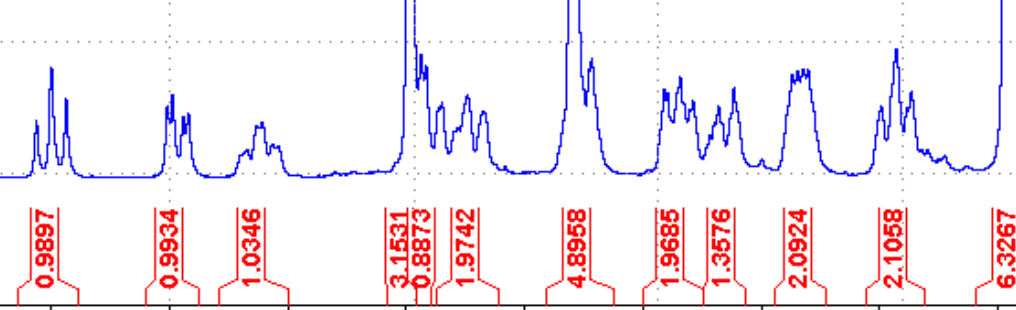

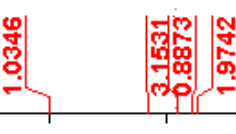

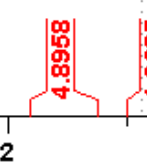

圆圆
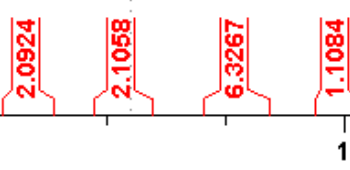

怘|
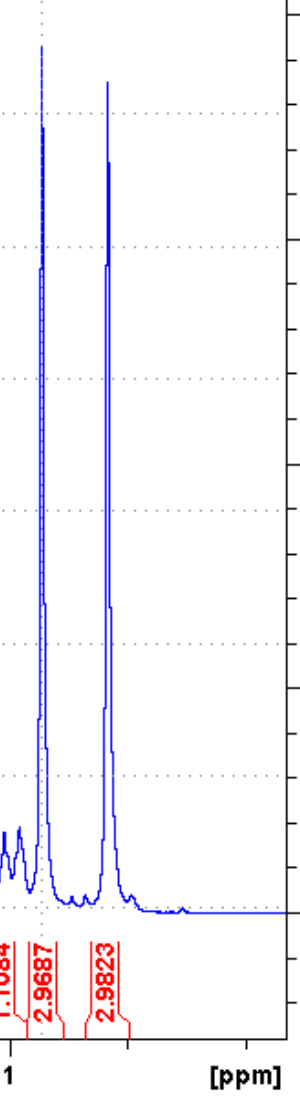

S18. ${ }^{1} \mathrm{H}$ NMR spectrum of Higginsianin C (3) $\left(\mathrm{CD}_{3} \mathrm{OD}, 500 \mathrm{MHz}\right)$. 


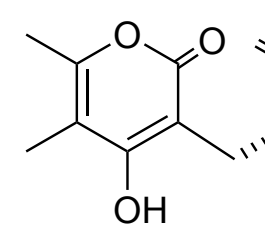

Higginsianin $\mathrm{C}$
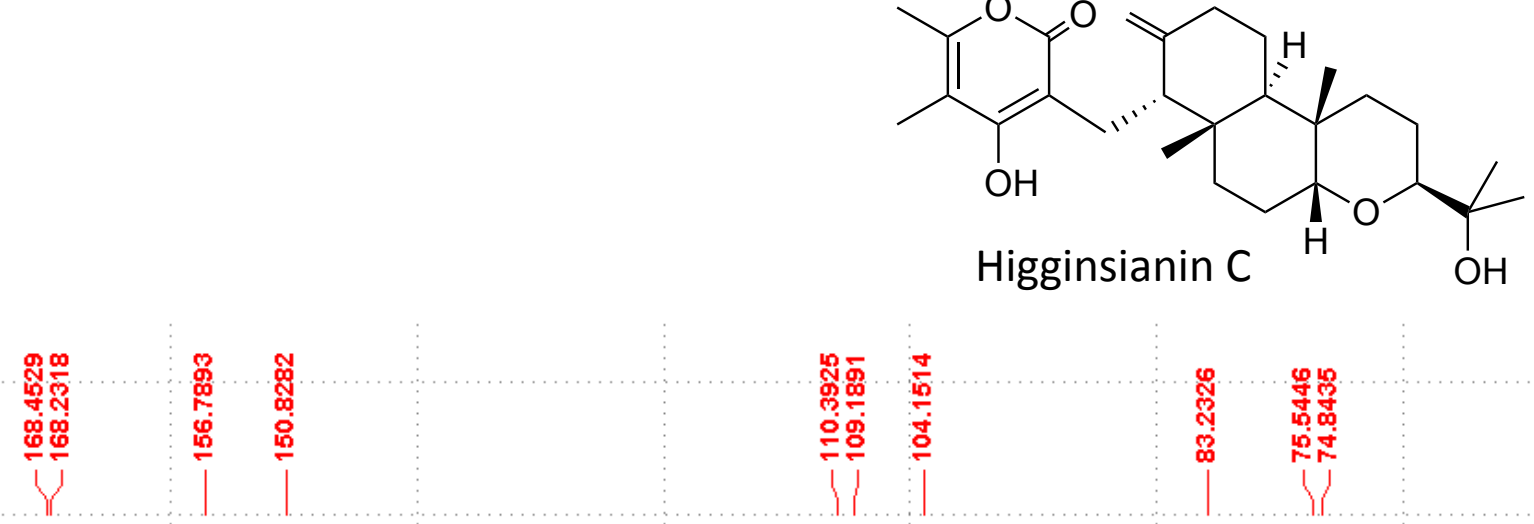

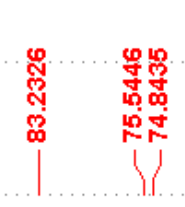
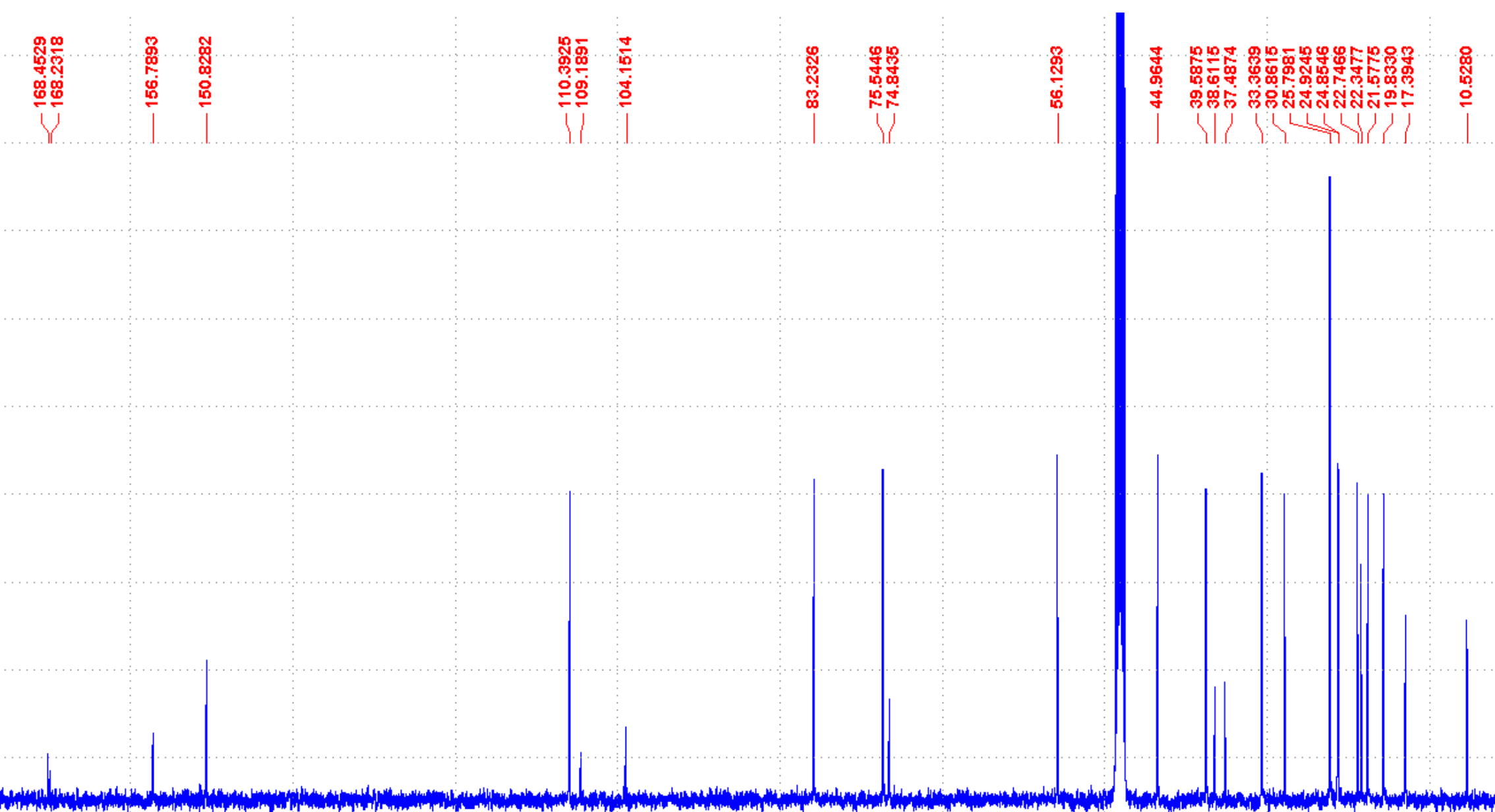

S19. ${ }^{13} \mathrm{C}$ NMR spectrum of Higginsianin C (3) ( $\left.\mathrm{CD}_{3} \mathrm{OD}, 125 \mathrm{MHz}\right)$. 


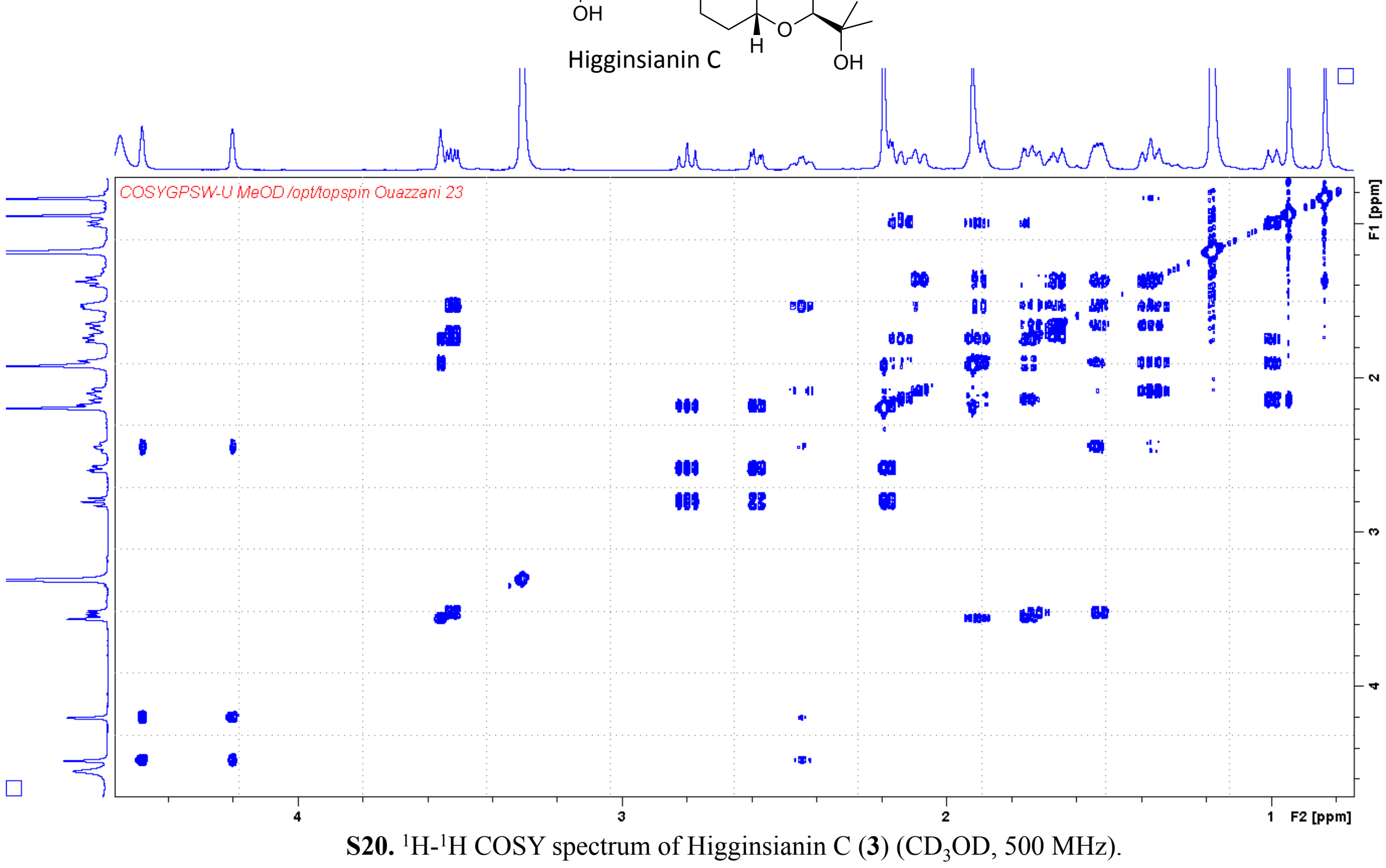




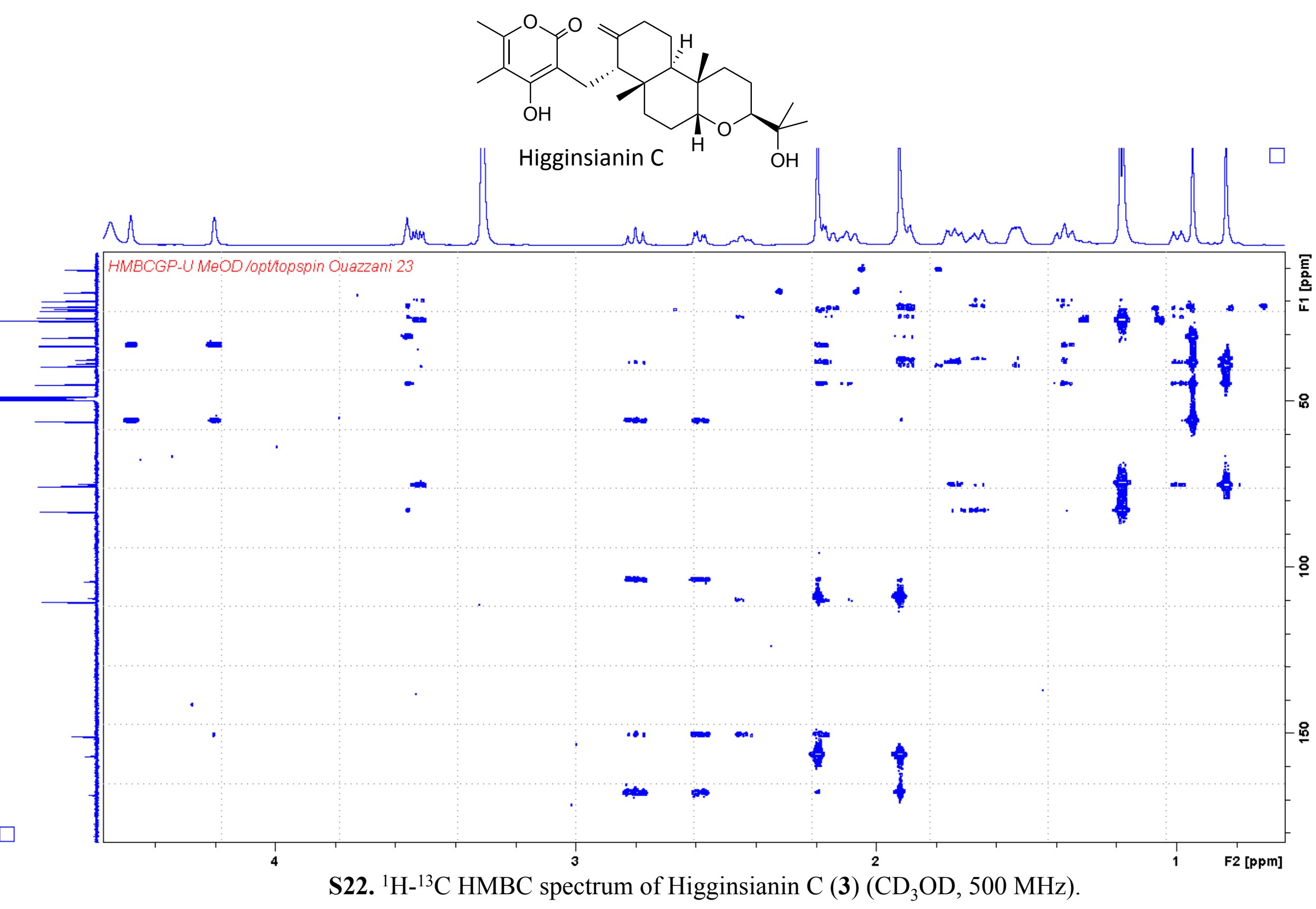




\section{Elemental Composition Report}

\section{Single Mass Analysis}

Tolerance $=10.0$ PPM / DBE: $\min =-1.5, \max =100.0$

Element prediction: Off

Number of isotope peaks used for $\mathrm{i}-\mathrm{FIT}=9$

Monoisotopic Mass, Even Electron Ions

2418 formula(e) evaluated with 12 results within limits (all results (up to 1000) for each mass)

Elements Used:

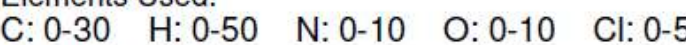

17-Jan-2018 3::2::4

1: TOF MS ES+

LCT Premier XE KE483

OUAZZANI dallery1-5 25 (0.662) $\mathrm{Cm}(17: 35)$

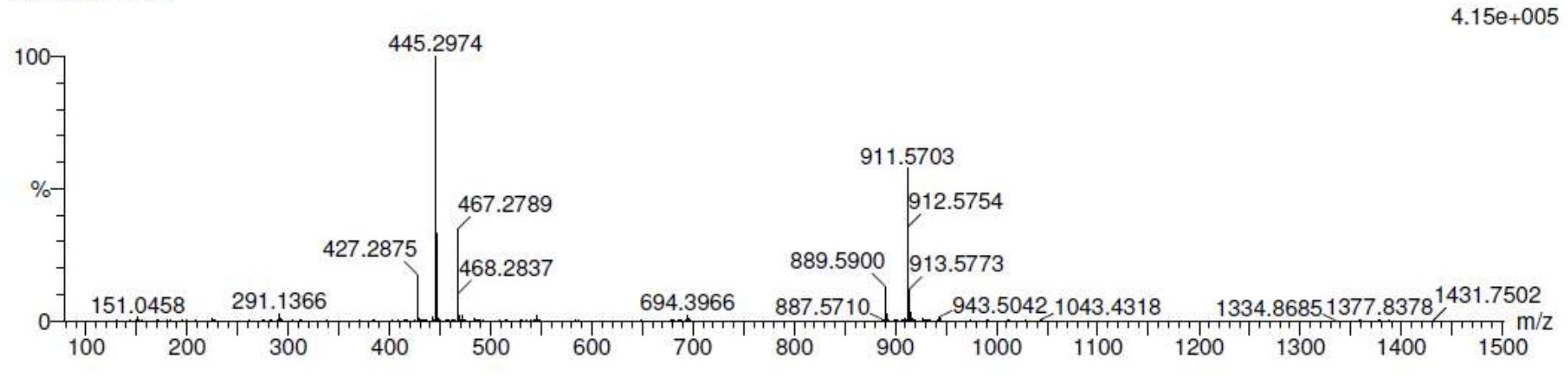

Minimum:

Maximum:

Mass

Calc. Mass

445.2974

445.2954

445.2967

445.3013

445.2999

445.2986

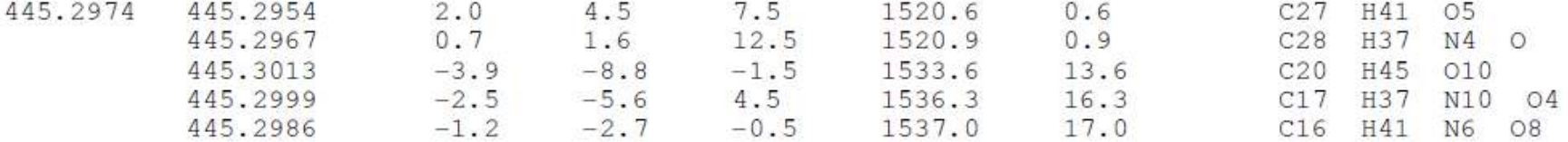

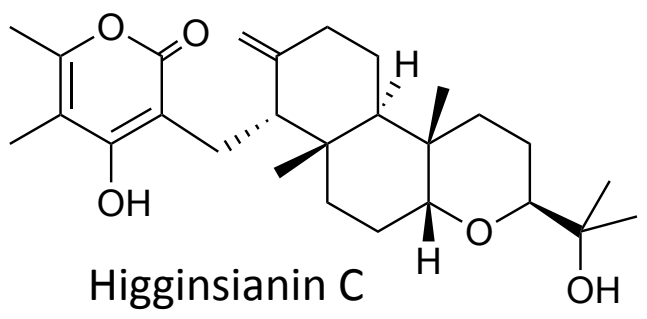

Page 1

S24. HRESIMS of Higginsianin C (3) 


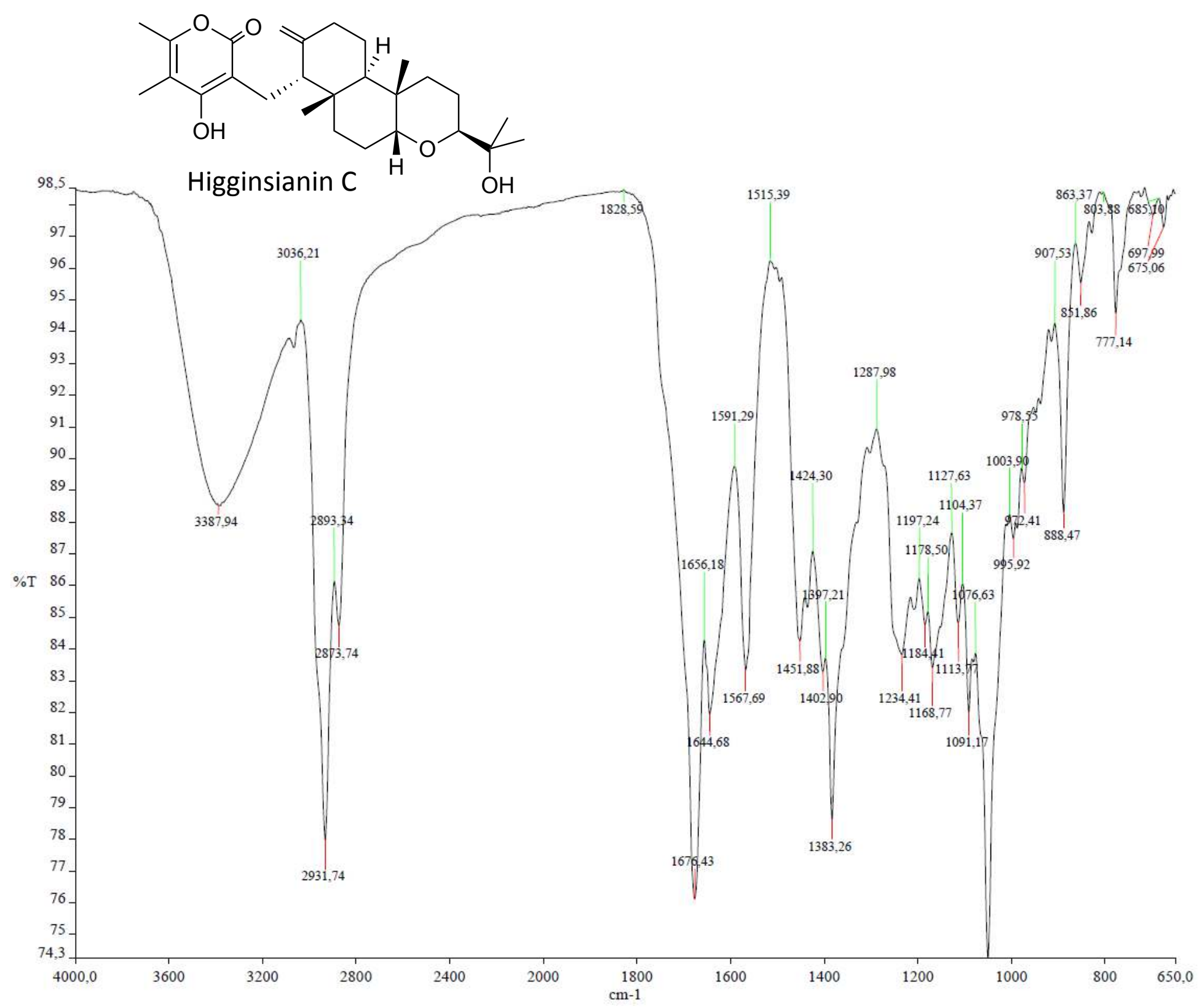

S25. IR spectrum of Higginsianin C (3) 


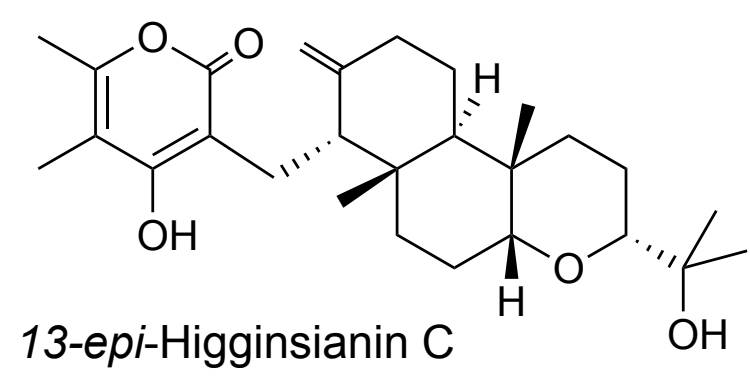

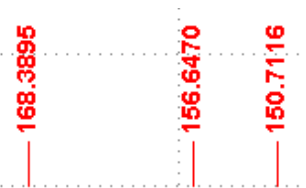

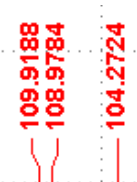

装章
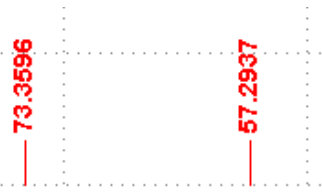

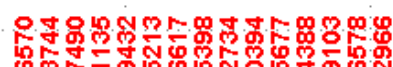

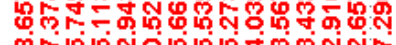

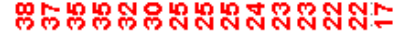
LIL

ญ্তু

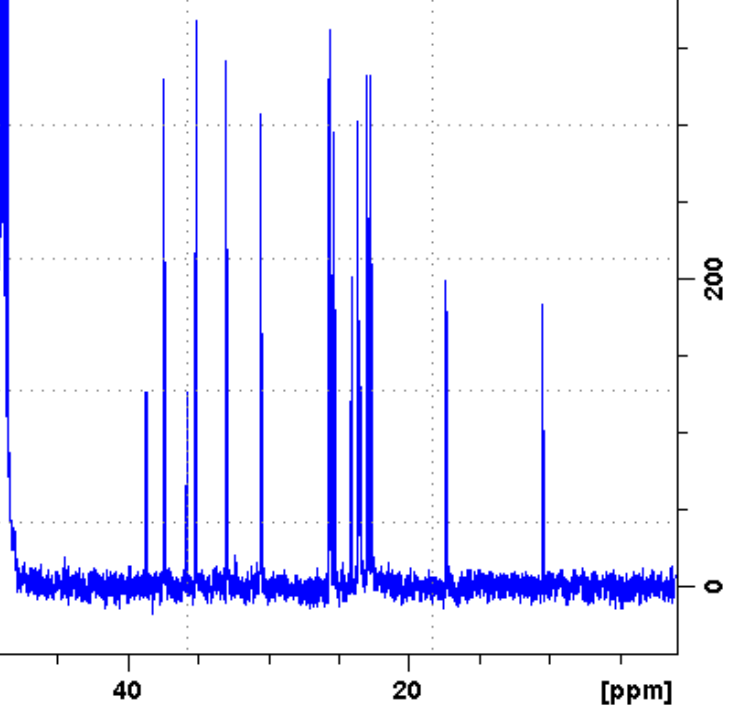

S27. ${ }^{13} \mathrm{C}$ NMR spectrum of 13-epi-higginsianin $\mathrm{C}(4)\left(\mathrm{CD}_{3} \mathrm{OD}, 125 \mathrm{MHz}\right)$. 


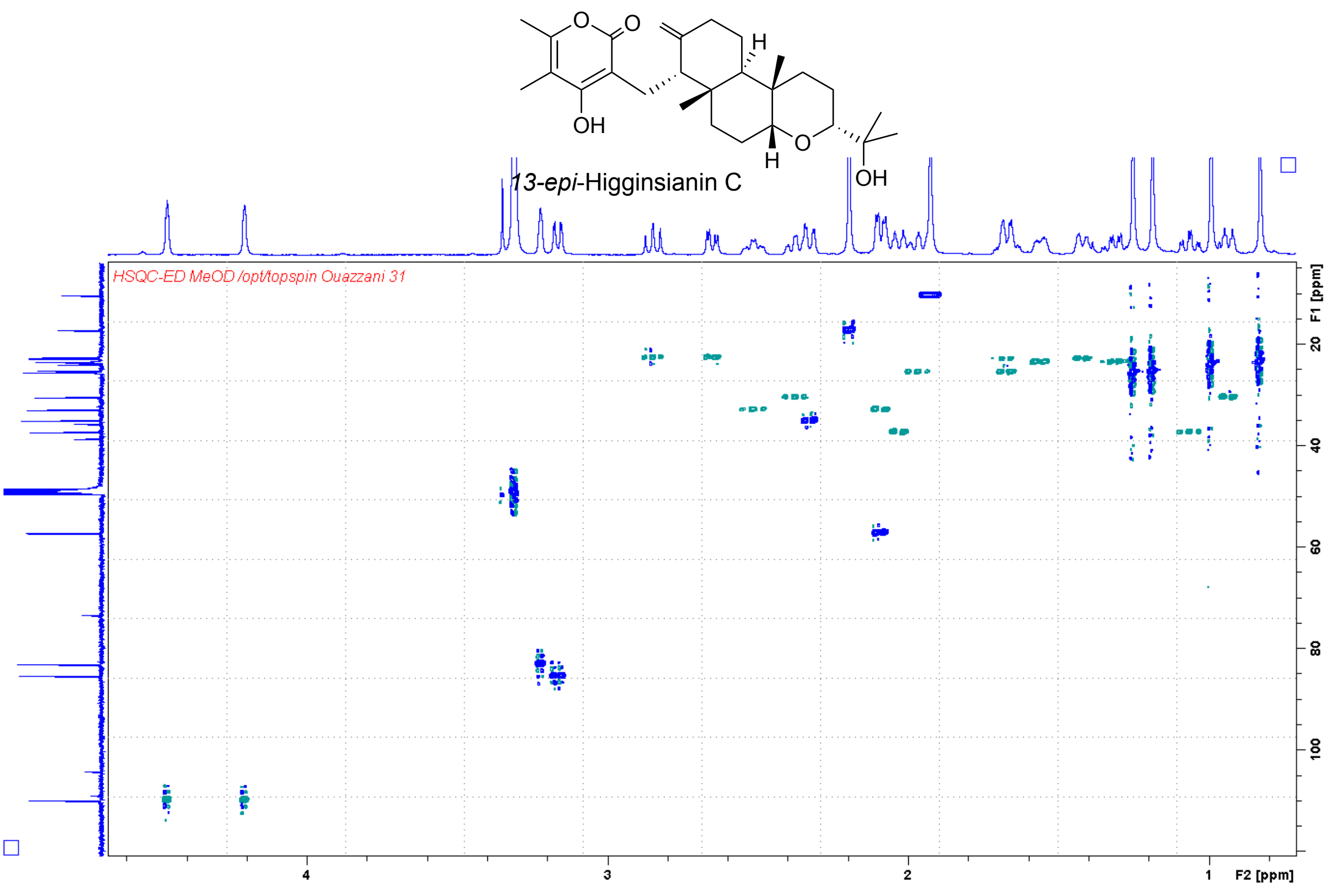

S29. ${ }^{1} \mathrm{H}-{ }^{13} \mathrm{C}$ HSQC-ED spectrum of 13-epi-higginsianin $\mathrm{C}(4)\left(\mathrm{CD}_{3} \mathrm{OD}, 500 \mathrm{MHz}\right)$. 


\section{Elemental Composition Keport}

\section{Single Mass Analysis}

Tolerance $=10.0$ PPM / DBE: $\min =-1.5, \max =100.0$

Element prediction: Off

Number of isotope peaks used for i-FIT $=9$

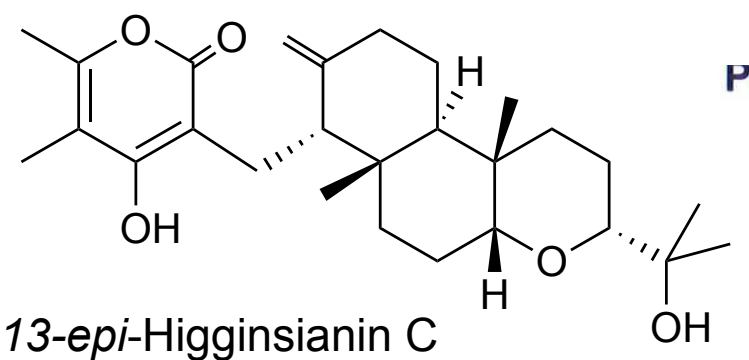

Page 1

Monoisotopic Mass, Even Electron Ions

462 formula(e) evaluated with 6 results within limits (all results (up to 1000) for each mass)

Elements Used:

$\begin{array}{llll}\text { C: } 0-30 & \mathrm{H}: 0-50 & \mathrm{~N}: 0-10 & \text { O: } 0-10\end{array}$

OUAZZANI_glegoff54-3 $23(0.608) \mathrm{Cm}(17: 28-37: 69 \times 2.000)$

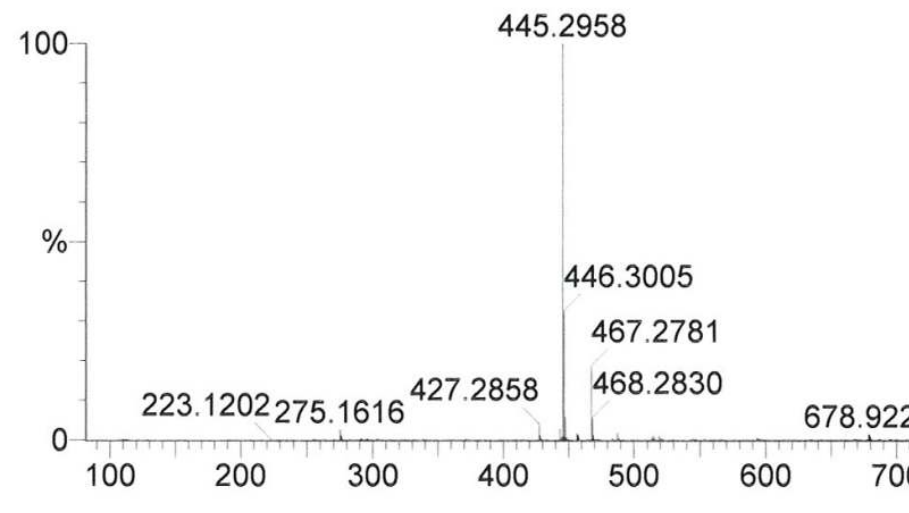

Minimum:

Maximum:

Mass

445.2958
Calc. Mass

445.2954

445.2967

445.2986

445.2927

445.2999

445.2914

$\begin{array}{lll}5.0 & 10.0 & -1.5 \\ & 100.0\end{array}$

$\mathrm{mDa}$

PPM

DBE

i-FIT

i-FIT (Norm)

Eormula

0.4

0.9

$-2.0$

7.5

12.5

1039.5

1041.8

1058.4

0.1

2. 4

19.1

3.1

$-4.1$

7.0

8.5

1050.3

1057.6

10.9

18.3

4. 4

9.9

3.5

13.1

$\begin{array}{llll}\text { C27 } & \text { H41 } & \text { O5 } & \\ \text { C28 } & \text { H37 } & \text { N4 } & \text { O } \\ \text { C16 } & \text { H41 } & \text { N6 } & \text { O8 } \\ \text { C23 } & \text { H37 } & \text { N6 } & \text { O3 } \\ \text { C17 } & \text { H37 } & \text { N10 } & \text { O4 } \\ \text { C22 } & \text { H41 } & \text { N2 } & \text { O7 }\end{array}$

S31. HRESIMS of 13-epi-higginsianin C (4) 


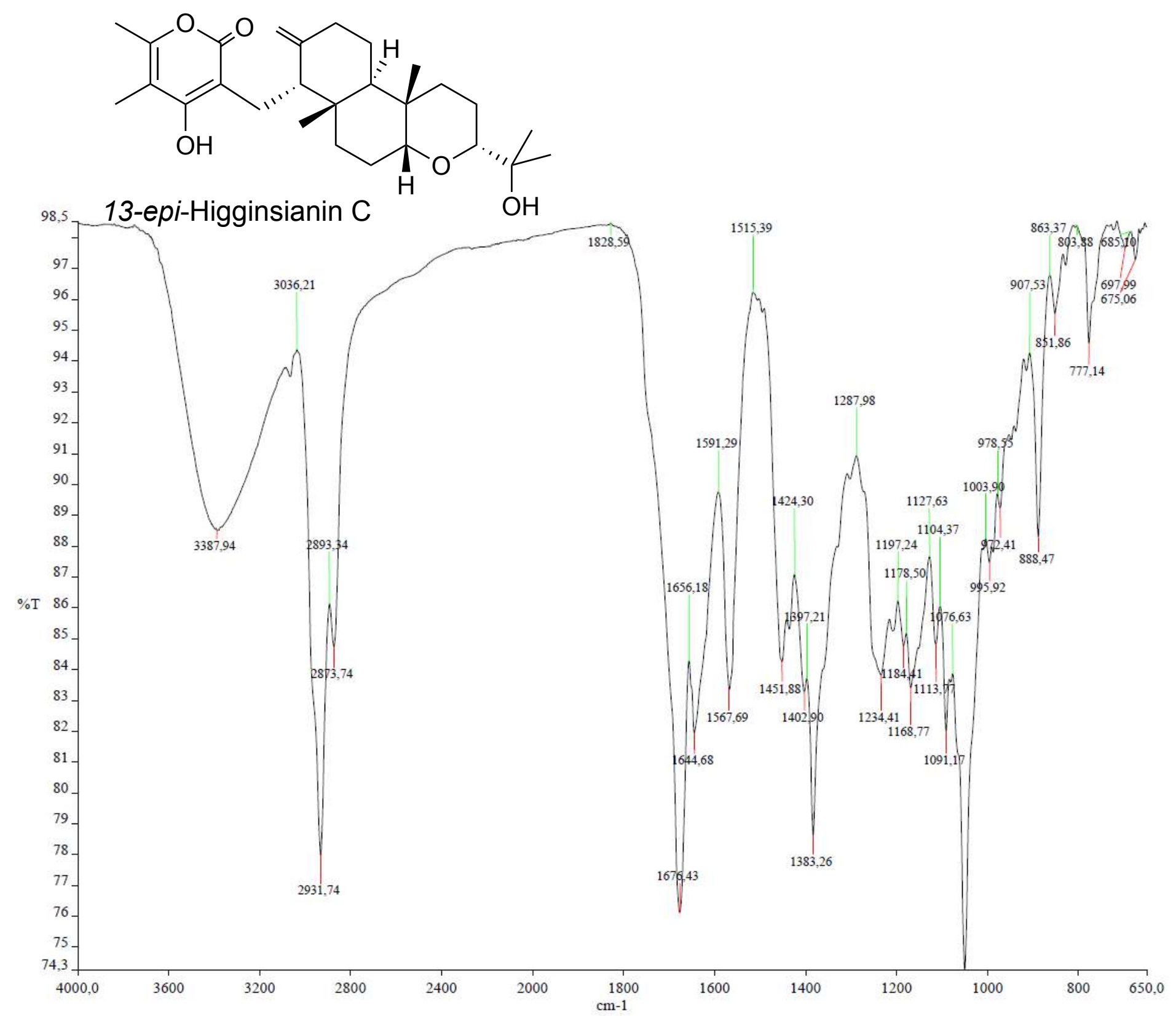

S32. IR spectrum of 13-epi-higginsianin C (4) 

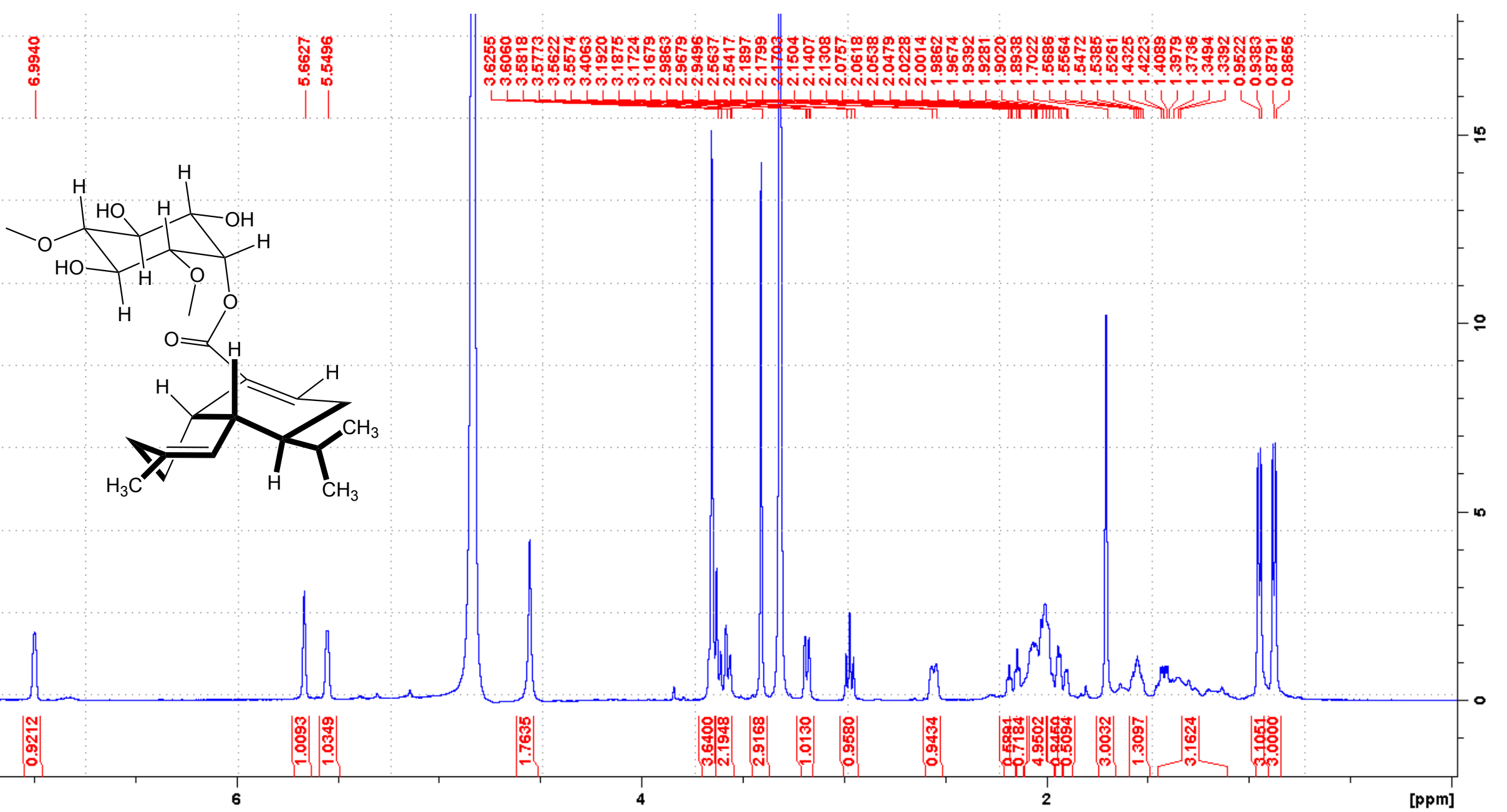

S33. ${ }^{1} \mathrm{H}$ NMR spectrum of sclerosporide (5) $\left(\mathrm{CD}_{3} \mathrm{OD}, 500 \mathrm{MHz}\right)$. 


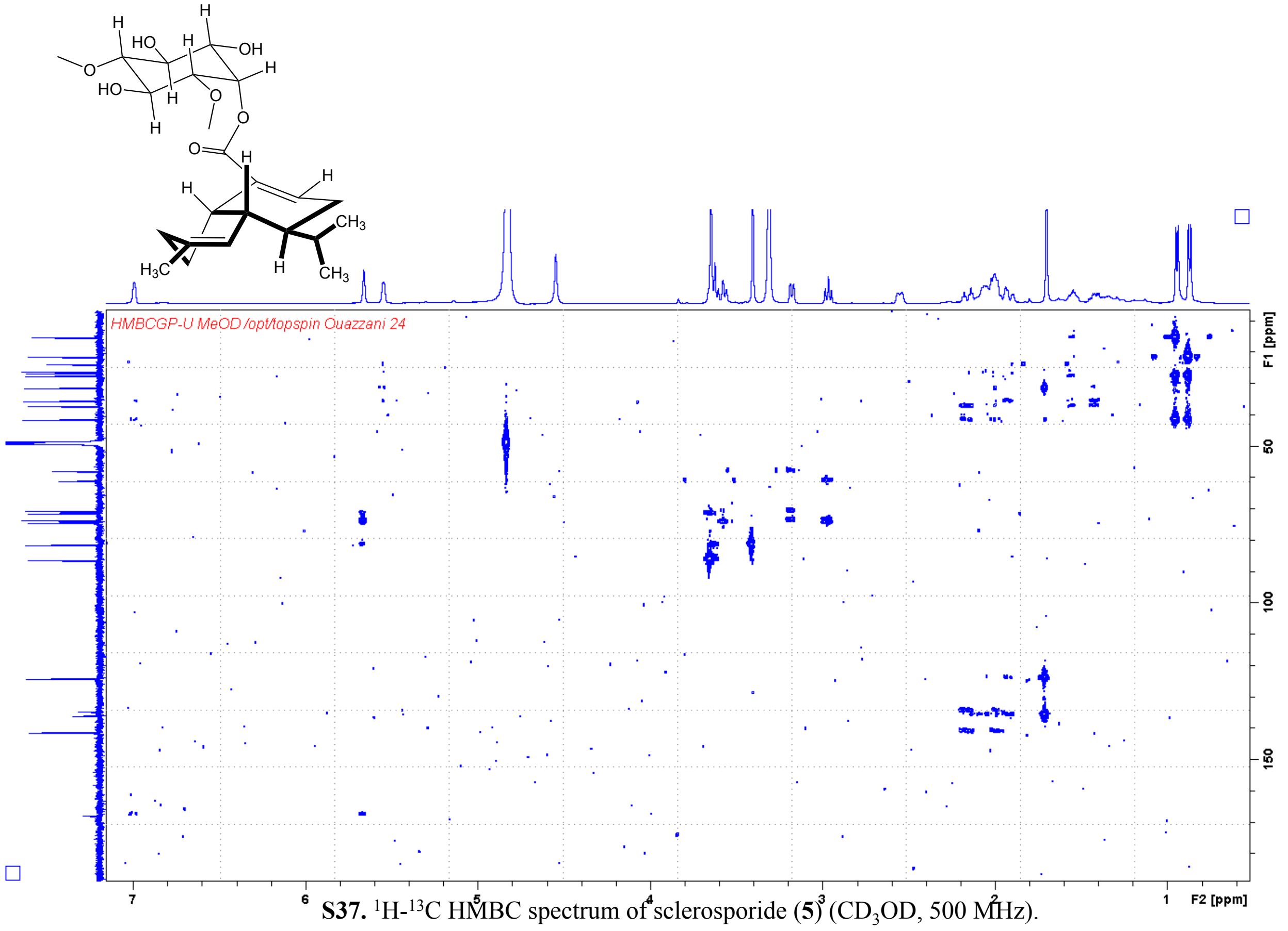




\section{Elemental Composition Report}

Single Mass Analysis

Tolerance $=10.0$ PPM / DBE: $\min =-1.5, \max =100.0$

Element prediction: Off

Number of isotope peaks used for $\mathrm{i}-\mathrm{FIT}=9$

Monoisotopic Mass, Even Electron Ions

245 formula(e) evaluated with 2 results within limits (all results (up to 1000) for each mass)

Elements Used:

C: $0-70 \quad \mathrm{H}: 0-100 \quad$ O: $0-50 \quad \mathrm{Cl}: 0-2$

OUAZZANI_arcile116-4 $21(0.573) \mathrm{Cm}(17: 31)$
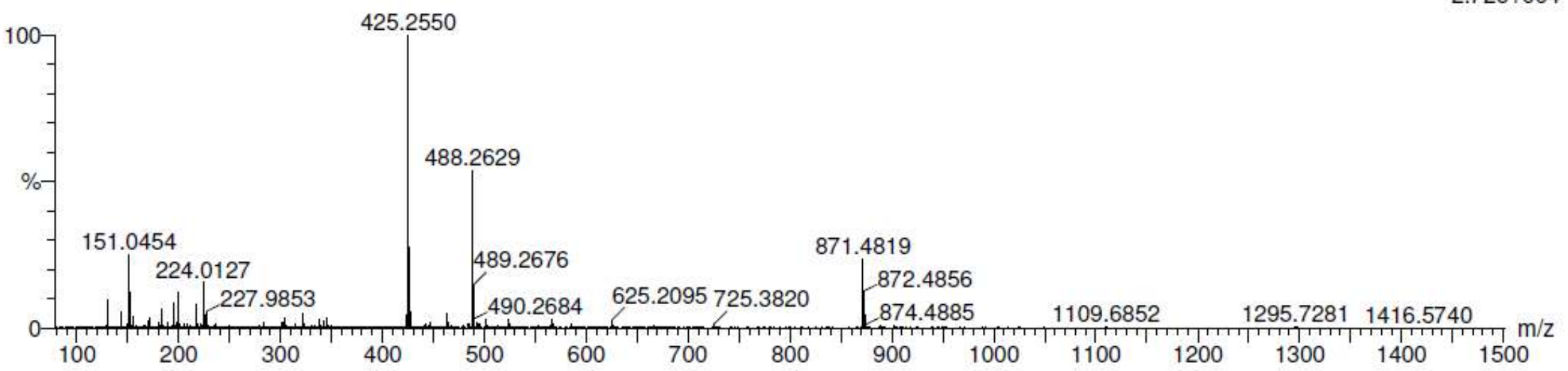

Minimum:

Maximum:

Mass

Calc. Mass

425.2552

425.2539

425.2589

\section{0}

10.0

$-1.5$

100.0

$\begin{array}{lll}\text { mDa } & \text { PPM } & \text { DBE } \\ 1.3 & 3.1 & 5.5 \\ -3.7 & -8.7 & 0.5\end{array}$

i-FIT

i-FIT (Norm) Formula

1033.5

1069.5

0.0

36.0

C23 $\mathrm{H} 37 \quad 07$

$\begin{array}{llll}\mathrm{C} 22 & \mathrm{H} 43 & \mathrm{O} 3 & \mathrm{C} 12\end{array}$




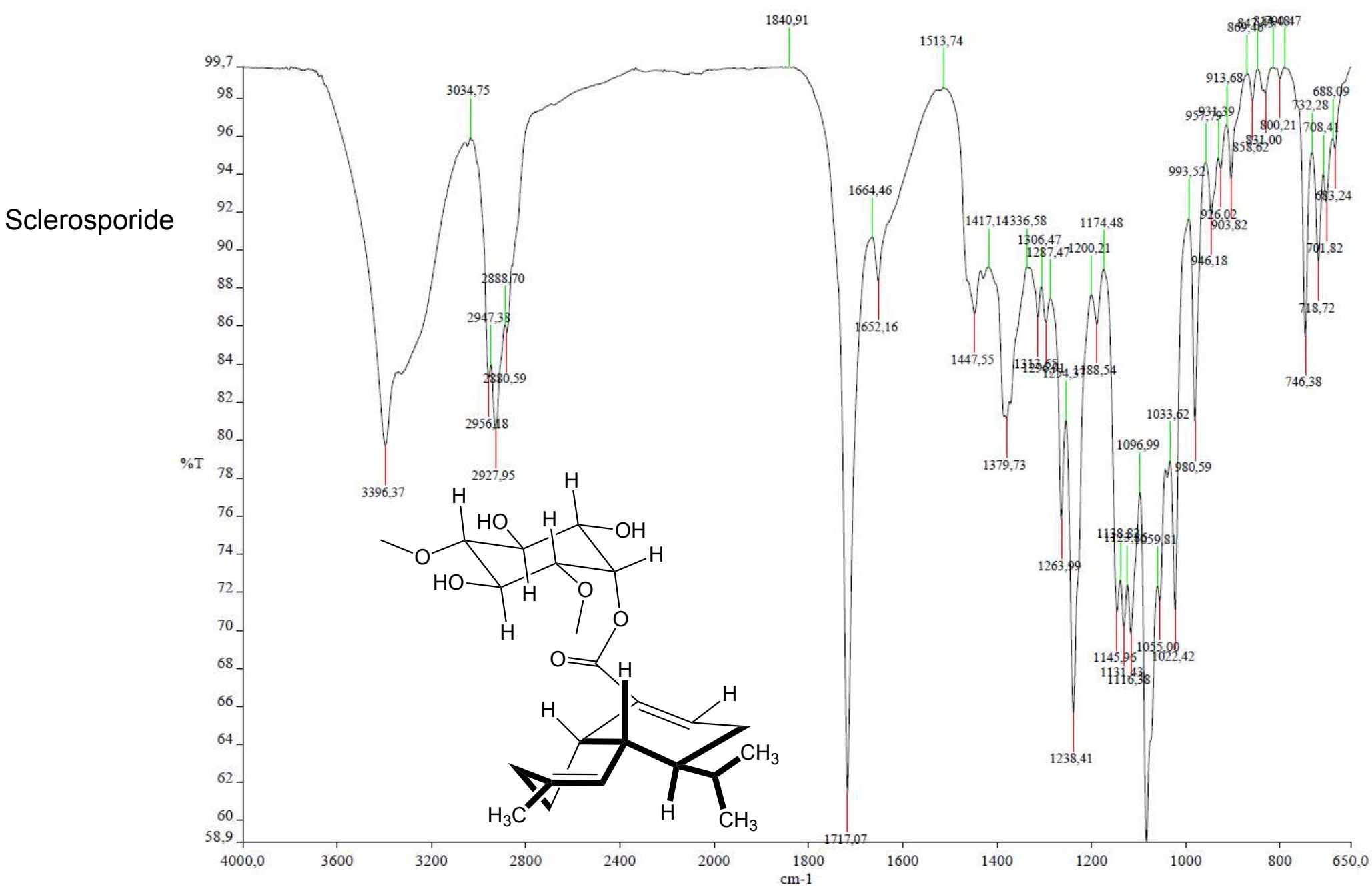

S40. IR spectrum of sclerosporide (5) 


\begin{tabular}{ccccccc}
\hline & $\delta_{\text {exp }}(3)$ & $\delta_{\text {calcd }}(3)$ & $\delta_{\text {diff }}(3)$ & $\delta_{\text {exp }}(4)$ & $\delta_{\text {calcd }}(\mathbf{4})$ & $\delta_{\text {diff }}(\mathbf{4})$ \\
\hline $\mathrm{H}-1$ & 1.38 & 1.45 & 0.07 & 1.31 & 1.44 & 0.13 \\
$\mathrm{H}-1$ & 1.56 & 1.47 & 0.09 & 1.56 & 1.58 & 0.02 \\
$\mathrm{H}-2$ & 2.09 & 2.12 & 0.03 & 2.09 & 1.91 & 0.18 \\
$\mathrm{H}-2$ & 2.47 & 2.55 & 0.08 & 2.51 & 2.80 & 0.29 \\
$\mathrm{H}-4$ & 2.17 & 2.29 & 0.12 & 2.09 & 2.12 & 0.03 \\
$\mathrm{H}-6$ & 1.02 & 0.79 & 0.23 & 0.93 & 0.93 & 0.00 \\
$\mathrm{H}-6$ & 2.16 & 1.99 & 0.17 & 2.39 & 2.12 & 0.27 \\
$\mathrm{H}-7$ & 1.77 & 1.72 & 0.05 & 1.69 & 1.56 & 0.13 \\
$\mathrm{H}-7$ & 1.93 & 1.87 & 0.06 & 1.98 & 1.87 & 0.11 \\
$\mathrm{H}-8$ & 3.56 & 3.77 & 0.21 & 3.22 & 3.09 & 0.13 \\
$\mathrm{H}-10$ & 1.91 & 1.67 & 0.24 & 2.33 & 2.46 & 0.13 \\
$\mathrm{H}-11$ & 1.38 & 1.32 & 0.06 & 2.03 & 2.13 & 0.10 \\
$\mathrm{H}-11$ & 1.66 & 1.69 & 0.03 & 1.06 & 0.92 & 0.14 \\
$\mathrm{H}-12$ & 1.53 & 1.48 & 0.05 & 1.67 & 2.04 & 0.37 \\
$\mathrm{H}-12$ & 1.73 & 1.55 & 0.18 & 1.42 & 1.35 & 0.07 \\
$\mathrm{H}-13$ & 3.53 & 3.46 & 0.07 & 3.16 & 3.14 & 0.02 \\
$\mathrm{Me}-15$ & 1.19 & 1.17 & 0.02 & 1.19 & 1.03 & 0.16 \\
$\mathrm{Me}-16$ & 1.17 & 1.17 & 0.00 & 1.26 & 1.26 & 0.00 \\
$\mathrm{Me}-17$ & 0.83 & 0.78 & 0.05 & 0.83 & 0.74 & 0.09 \\
$\mathrm{Me}-18$ & 0.94 & 0.98 & 0.04 & 0.99 & 1.03 & 0.04 \\
$\mathrm{H}-19$ & 4.48 & 4.68 & 0.20 & 4.48 & 4.60 & 0.12 \\
$\mathrm{H}-19$ & 4.20 & 4.27 & 0.07 & 4.21 & 4.29 & 0.08 \\
$\mathrm{H}-20$ & 2.60 & 2.52 & 0.08 & 2.65 & 2.63 & 0.02 \\
$\mathrm{H}-20$ & 2.81 & 2.70 & 0.11 & 2.85 & 2.92 & 0.07 \\
$\mathrm{Me}-26$ & 1.92 & 1.85 & 0.07 & 1.93 & 1.78 & 0.15 \\
$\mathrm{Me}-27$ & 2.19 & 2.19 & 0.00 & 2.20 & 2.15 & 0.05 \\
\hline $\mathrm{MUE}$ & & & $\mathbf{0 . 0 9}$ & & & 0.11 \\
\hline $\mathrm{RMSE}$ & & & 0.11 & & & 0.14 \\
\hline
\end{tabular}

a MUE : mean unsigned error

b RMSE : root mean square error

S41. Comparison of ${ }^{1} \mathrm{H}$ NMR Data from Experimental Chemical Shifts $\left(\delta_{\text {exp }}\right)$ vs Calculated Chemical Shifts by DFT-NMR $\left(\delta_{\text {calcd }}\right)$ for compounds 3 and $\mathbf{4}\left(\delta_{\mathrm{H}}\right.$ in ppm) 


\begin{tabular}{ccccccc}
\hline & $\delta_{\exp }(\mathbf{3})$ & $\delta_{\text {calcd }}(\mathbf{3})$ & $\delta_{\text {diff }}(\mathbf{3})$ & $\delta_{\exp }(\mathbf{4})$ & $\delta_{\text {calcd }}(\mathbf{4})$ & $\delta_{\text {diff }}(\mathbf{4})$ \\
\hline C-1 & 24.70 & 27.50 & 2.80 & 23.50 & 25.25 & 1.75 \\
C-2 & 33.30 & 35.24 & 1.94 & 33.00 & 33.58 & 0.58 \\
C-3 & 150.80 & 157.43 & 6.63 & 150.70 & 157.12 & 6.42 \\
C-4 & 56.10 & 56.57 & 0.47 & 57.20 & 58.25 & 1.05 \\
C-5 & 38.50 & 42.73 & 4.23 & 38.70 & 42.82 & 4.12 \\
C-6 & 30.80 & 31.50 & 0.70 & 30.60 & 31.97 & 1.37 \\
C-7 & 25.80 & 24.52 & 1.28 & 25.60 & 27.93 & 2.33 \\
C-8 & 75.50 & 79.89 & 4.39 & 83.10 & 87.30 & 4.20 \\
C-9 & 37.50 & 40.23 & 2.73 & 35.80 & 41.93 & 6.13 \\
C-10 & 45.00 & 46.96 & 1.96 & 35.20 & 37.07 & 1.87 \\
C-11 & 39.60 & 41.68 & 2.08 & 37.40 & 38.84 & 1.44 \\
C-12 & 19.80 & 19.12 & 0.68 & 22.90 & 23.49 & 0.59 \\
C-13 & 83.20 & 84.92 & 1.72 & 85.50 & 86.19 & 0.69 \\
C-14 & 74.80 & 79.38 & 4.58 & 73.40 & 75.33 & 1.93 \\
C-15 & 25.80 & 24.72 & 1.08 & 25.30 & 23.43 & 1.87 \\
C-16 & 25.80 & 25.85 & 0.05 & 25.70 & 26.89 & 1.19 \\
C-17 & 21.60 & 18.41 & 3.19 & 23.50 & 22.09 & 1.41 \\
C-18 & 22.70 & 19.96 & 2.74 & 24.10 & 23.04 & 1.06 \\
C-19 & 110.40 & 106.16 & 4.24 & 110.00 & 106.21 & 3.79 \\
C-20 & 22.70 & 25.03 & 2.33 & 22.70 & 25.37 & 2.67 \\
C-21 & 104.10 & 106.38 & 2.28 & 104.50 & 106.30 & 1.80 \\
C-22 & 168.40 & 164.03 & 4.37 & 167.70 & 163.49 & 4.21 \\
C-23 & 109.20 & 104.78 & 4.42 & 108.60 & 104.95 & 3.65 \\
C-24 & 156.80 & 160.74 & 3.94 & 156.80 & 161.14 & 4.34 \\
C-25 & 168.20 & 162.81 & 5.39 & 168.20 & 162.95 & 5.25 \\
\hline MUE ${ }^{\mathrm{a}}$ & & & $\mathbf{2 . 6 8}$ & & & $\mathbf{2 . 5 1}$ \\
\hline RMSE & & & 3.15 & & & 3.03 \\
\hline
\end{tabular}

a MUE : mean unsigned error

b RMSE : root mean square error

S42. Comparison of ${ }^{13} \mathrm{C}$ NMR Data from Experimental Chemical Shifts $\left(\delta_{\text {exp }}\right)$ vs Calculated Chemical Shifts by DFT$\operatorname{NMR}\left(\delta_{\text {calcd }}\right)$ for compounds 3 and $\mathbf{4}\left(\delta_{\mathrm{H}}\right.$ in ppm) 


\begin{tabular}{|c|c|c|c|}
\hline & $\delta_{\exp }(5)$ & $\delta_{\text {calcd }}(\mathbf{5})$ & $\delta_{\text {diff }}(5)$ \\
\hline $\mathrm{H}-1$ & 2.55 & 2.46 & 0.09 \\
\hline $\mathrm{H}-2$ & 1.42 & 1.41 & 0.01 \\
\hline $\mathrm{H}-2$ & 2.00 & 2.08 & 0.08 \\
\hline $\mathrm{H}-3$ & 2.08 & 2.20 & 0.12 \\
\hline $\mathrm{H}-3$ & 1.91 & 1.85 & 0.06 \\
\hline $\mathrm{H}-5$ & 5.55 & 5.73 & 0.18 \\
\hline $\mathrm{H}-6$ & 2.01 & 2.13 & 0.12 \\
\hline $\mathrm{H}-7$ & 1.55 & 1.65 & 0.10 \\
\hline $\mathrm{H}-8$ & 2.16 & 2.05 & 0.11 \\
\hline $\mathrm{H}-8$ & 2.16 & 2.16 & 0.00 \\
\hline $\mathrm{H}-9$ & 6.99 & 7.56 & 0.57 \\
\hline $\mathrm{H}-11$ & 2.05 & 2.15 & 0.10 \\
\hline $\mathrm{Me}-12$ & 0.87 & 0.87 & 0.00 \\
\hline Me-13 & 0.95 & 0.95 & 0.00 \\
\hline $\mathrm{Me}-15$ & 1.70 & 1.73 & 0.03 \\
\hline $\mathrm{H}-1^{\prime}$ & 5.66 & 5.02 & 0.64 \\
\hline H-2' & 3.18 & 3.20 & 0.02 \\
\hline H-3' & 3.62 & 3.98 & 0.36 \\
\hline H-4' & 2.94 & 2.79 & 0.15 \\
\hline H-5' & 3.64 & 3.67 & 0.03 \\
\hline H-6' & 3.65 & 3.44 & 0.21 \\
\hline Me-7' & 3.41 & 3.66 & 0.25 \\
\hline Me-8' & 3.65 & 3.69 & 0.04 \\
\hline MUE $^{\mathrm{a}}$ & & & 0.14 \\
\hline RMSE $^{\text {b }}$ & & & 0.22 \\
\hline
\end{tabular}

a MUE : mean unsigned error

b RMSE : root mean square error

S43. Comparison of ${ }^{1} \mathrm{H}$ NMR Data from Experimental Chemical Shifts $\left(\delta_{\text {exp }}\right)$ vs Calculated Chemical Shifts by DFT-NMR ( $\left.\delta_{\text {calcd }}\right)$ for compound 5 ( $\delta_{\mathrm{H}}$ in ppm) 


\begin{tabular}{cccc}
\hline & $\delta_{\text {exp }}(\mathbf{5})$ & $\delta_{\text {calcd }}(\mathbf{5})$ & $\delta_{\text {diff }}(\mathbf{5})$ \\
\hline C-1 & 35.80 & 37.75 & 1.95 \\
C-2 & 26.80 & 28.00 & 1.20 \\
C-3 & 31.70 & 31.80 & 0.10 \\
C-4 & 136.20 & 140.66 & 4.46 \\
C-5 & 124.30 & 124.84 & 0.54 \\
C-6 & 37.40 & 39.29 & 1.89 \\
C-7 & 41.80 & 42.74 & 0.94 \\
C-8 & 26.50 & 28.01 & 1.51 \\
C-9 & 141.50 & 152.23 & 10.73 \\
C-10 & 134.50 & 135.42 & 0.92 \\
C-11 & 27.70 & 29.87 & 2.17 \\
C-12 & 15.50 & 12.31 & 3.19 \\
C-13 & 21.70 & 21.05 & 0.65 \\
C-14 & 168.10 & 173.48 & 5.38 \\
C-15 & 24.00 & 24.55 & 0.55 \\
C-1' & 70.90 & 80.78 & 9.88 \\
C-2' & 81.70 & 81.69 & 0.01 \\
C-3' & 74.00 & 79.09 & 5.09 \\
C-4' & 86.50 & 87.32 & 0.82 \\
C-5' & 74.50 & 78.66 & 4.16 \\
C-6' & 71.60 & 77.12 & 5.52 \\
C-7' & 58.00 & 60.86 & 2.86 \\
C-8 $^{\prime}$ & 61.20 & 60.67 & 0.53 \\
\hline MUE $^{a}$ & & & $\mathbf{2 . 8 3}$ \\
\hline RMSE & \\
\hline & & & 4.03 \\
\hline
\end{tabular}

a MUE : mean unsigned error

b RMSE : root mean square error

S44. Comparison of ${ }^{13} \mathrm{C}$ NMR Data from Experimental Chemical Shifts $\left(\delta_{\text {exp }}\right)$ vs Calculated Chemical Shifts by DFT$\operatorname{NMR}\left(\delta_{\text {calcd }}\right)$ for compound $\mathbf{5}\left(\delta_{\mathrm{H}}\right.$ in ppm) 
Colletochlorin D 9: colorless oil; IR $v_{\max } 3173,2969,1614,1421,1278,1100 \mathrm{~cm}-1$; NMR data, Table 1 and supporting information; HRESIMS $m / z$ 255.0783 [M+H] (calculated from $\mathrm{C}_{13} \mathrm{H}_{16} \mathrm{O}_{3} \mathrm{Cl} 255.0788$ ).

Colletorin A 6: amorphous solid; IR $v_{\max } 3440,2922,1630,1482,1371,1223,1060 \mathrm{~cm}-1 ;{ }^{1} \mathrm{H} \mathrm{NMR}_{(\mathrm{CDCl}}$; $\left.500 \mathrm{MHz}\right) 12.69$ (s; 1H; HO-2); 10.10 (bs; 1H; CHO-7); 6.23 (bs; 1H; HO-4); 6.19 (s; 1H; 5-H) ; 5.29 (t; 1H; $6.7 \mathrm{~Hz} ; 9-\mathrm{H}) ; 3.40$ (d; 2H; 7.2Hz; 8H) ; 3.35 (dd; 1H; 10.4, 1.4 Hz; 14-H) ; 2.48 (s; 3H; 18-CH $) ; 2.27-2.15$ (m; 2H; 12$\mathrm{H}) ; 1.80\left(\mathrm{~s} ; 3 \mathrm{H} ; 11-\mathrm{CH}_{3}\right) ; 1.60-1.45(\mathrm{~m} ; 2 \mathrm{H} ; 13-\mathrm{H}) 1.18\left(\mathrm{~s} ; 3 \mathrm{H} ; 16-\mathrm{CH}_{3}\right) ; 1.14(\mathrm{~s} ; 3 \mathrm{H} ; 17-\mathrm{CH} 3) ;{ }^{13} \mathrm{C}$ NMR $(\mathrm{CDCl} ; 325 \mathrm{MHz}) \delta 193.0(\mathrm{CHO}-7) ; 163.8(\mathrm{C}-2) ; 162.5$ (C-4) ; 142.4 (C-6) ; 138.1 (C-10) ; 122.2 (C-9) ; 113.3 (C-1) ; 112.2 (C-3) ; 110.7 (C-5) ; 78.1 (C-14) ; 73.4 (C-15) ; $37.0(\mathrm{C}-12) ; 29.5$ (C-13) ; 26.7 (CH -16$) ; 23.3$ $\left(\mathrm{CH}_{3}-17\right) ; 21.0(\mathrm{C}-8) ; 18.2\left(\mathrm{CH}_{3}-18\right) ; 16.3\left(\mathrm{CH}_{3}-11\right)$; HRESIMS $\mathrm{m} / z 323.1862[\mathrm{M}+\mathrm{H}]^{+}\left(\right.$calcd for $\left.\mathrm{C}_{18} \mathrm{H}_{27} \mathrm{O}_{5} 323.1858\right)$.

Colletochlorin A 7: amorphous solid; $[\alpha]_{\mathrm{D}}{ }^{25}+20.50$ (c 0.4, MeOH); IR $v_{\max } 3325,1627,1374,1243 \mathrm{~cm}-1 ;{ }^{1} \mathrm{H} \mathrm{NMR}\left(\mathrm{CDCl}_{3} ; 500 \mathrm{MHz}\right) 12.69$ (s; $\left.1 \mathrm{H} ; \mathrm{HO}-2\right) ; 10.10$ (bs; 1H; CHO-7); 6.23 (bs; 1H; HO-4); 5.25 (t; 1H; $7.1 \mathrm{~Hz} ; 9-\mathrm{H}) ; 3.40$ (d; 2H; 7.2Hz; 8-H) ; 3.32 (dd; 1H; 10.4, 1.6Hz; 14-H) ; 2.60 (s; 3H; 18-CH $)$; 2.23-2.08 (m; 2H; 12$\mathrm{H}) ; 1.80\left(\mathrm{~s} ; 3 \mathrm{H} ; 11-\mathrm{CH}_{3}\right) ; 1.59-1.42(\mathrm{~m} ; 2 \mathrm{H} ; 13-\mathrm{H}) ; 1.18\left(\mathrm{~s} ; 3 \mathrm{H} ; 16-\mathrm{CH}_{3}\right) ; 1.14\left(\mathrm{~s} ; 3 \mathrm{H} ; 17-\mathrm{CH}_{3}\right) ;{ }^{13} \mathrm{C} \mathrm{NMR}(\mathrm{CDCl} ; 125 \mathrm{MHz}) \delta 193.3(\mathrm{CHO}-7) ; 162.4(\mathrm{C}-2) ; 156.5$ (C-4) ; 137.9 (C-6) ; 136.7 (C-10) ; 121.4 (C-9) ; 114.1 (C-3) ; 113.8 (C-1) ; 113.4 (C-5) ; 78.6 (C-14) ; 73.0 (C-15) ; 37.0 (C-12) ; 29.6 (C-13) ; 26.3 (CH -17$) ; 23.3$ $\left(\mathrm{CH}_{3}-16\right) ; 22.0(\mathrm{C}-8) ; 16.3\left(\mathrm{CH}_{3}-11\right) ; 14.5\left(\mathrm{CH}_{3}-18\right) ; \operatorname{HRESIMS~} m / z 357.1478[\mathrm{M}+\mathrm{H}]^{+}\left(\right.$calcd for $\left.\mathrm{C}_{18} \mathrm{H}_{26} \mathrm{ClO}_{5} 357.1469\right)$.

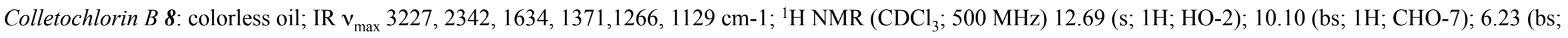
1H; HO-4); 5.21 (bt; 1H; 7.2 Hz; 9-H) ; 5.04 (bt; 1H; $6.5 \mathrm{~Hz} ; 14-\mathrm{H}) ; 3.40$ (d; 2H; $7.2 \mathrm{~Hz} ; 8-\mathrm{H}) ; 2.60$ (s; 3H; 18-CH $) ; 2.04$ (m; 2H; 13-H) ; 1.98 (m; 2H; 12-H) ; 1.80 (s;

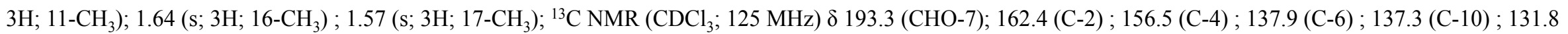
(C-15) ; $124.1(\mathrm{C}-14) ; 120.6(\mathrm{C}-9) ; 114.5$ (C-3) ; $113.8(\mathrm{C}-1) ; 113.5(\mathrm{C}-5) ; 39.9(\mathrm{C}-12) ; 26.7(\mathrm{C}-13) ; 26.5\left(\mathrm{CH}_{3}-16\right) ; 22.0(\mathrm{C}-8) ; 17.8\left(\mathrm{CH}_{3}-17\right) ; 16.3\left(\mathrm{CH}_{3}-11\right) ; 14.7$ $\left(\mathrm{CH}_{3}-18\right)$; HRESIMS $m / z 323.1404[\mathrm{M}+\mathrm{H}]^{+}$(calcd for $\left.\mathrm{C}_{18} \mathrm{H}_{24} \mathrm{O}_{3} \mathrm{Cl} 323.1414\right)$.

Higginsianin A: colorless crytal; $[\alpha]_{\mathrm{D}}{ }^{25}-64.5$ (c 0.3, MeOH) $\left([\alpha]_{\mathrm{D}}{ }^{25}-67.3, \mathrm{c} 0.3\right.$, according to ref 14$)$; IR $v_{\max } 3163,2908,1646,1614,1449,1279,1227,1067 \mathrm{~cm}-1$; NMR data, see Table 2 and supporting information; HRESIMS m/z 427.2852 [M+H] $]^{+}$calcd for $\left.\mathrm{C}_{27} \mathrm{H}_{39} \mathrm{O}_{4}, 427.2848\right)$.

Higginsianin B 11: colorless crytal; $[\alpha]_{\mathrm{D}}{ }^{25}-71.2(\mathrm{c} 0.4, \mathrm{MeOH})\left([\alpha]_{\mathrm{D}}{ }^{25}-68.8\right.$ (c 0.25 according to ref 14$) ; \mathrm{IR} v_{\max } 3211,2931,1643,1573,1433,1383,1203,1060 \mathrm{~cm}-1$; ${ }^{1} \mathrm{H}$ NMR (MeoD; 500 MHz) 5.17 (bt; 1H; 13-H); 4.50 (dd; 1H; 19-H); 4.24 (dd; 1H; 19-H); 3.65 (dd; 1H; 8-H); 2.84 (dd; 1H; 20-H); 2.67 (dd; $\left.1 \mathrm{H} ; 20-\mathrm{H}\right) ; 2,45$ (td; 1H; 2H); 2.33 (td; 1H; 6-H); 2.23 (s; 3H; 27-H); 2.19 (m, 1H; 12-H); 2.19 (dd; 1H; 4-H); 2.11 (dd; 1H; 2-H); 2.02 (m; 1H; 7-H); 1.99 (m;1H; $12-\mathrm{H}) ; 1.96$ (s; 3H; 26-H); 1.93 (dd; 1H; 10-H); 1.71 (s; 3H; 15-H); 1.67 (s; 3H; 16-H); 1.65 (m; 1H; 7-H); 1.63-1.35 (m; 2H; 1-H); 1.48 (td; 1H; 11-H); 1.31 (m;1H; 11-H); 1.02 (s; 3H; 18-H); 1.00 (td; 1H; 6-H); 0.89 (s; 3H; 17-H); ${ }^{13} \mathrm{C}$ NMR (MeOD; 125 MHz) $\delta 168.3$ (C-22); 168.2 (C-25); 156.9 (C-24); 150.6 (C-3); 131.6 (C-14); 127.1 (C-13); 110.0 (C-19); 108.8 (C-23); 104.3 (C-21); 73.6 (C-8); 56.7 (C-4); 41.4 (C-10); 41.2 (C-11); 40.4 (C-9); 39.0 (C-5); 33.0 (C-2); 29.9 (C-6); 27.1 (C-7); 25.9 (C-15); 24.1 (C-1); 23.6 (C-18);

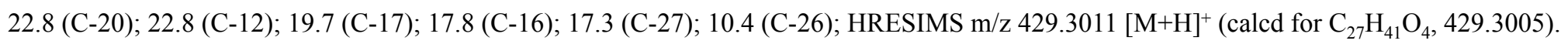

S45. Experimental data for known compounds isolated in this stury 

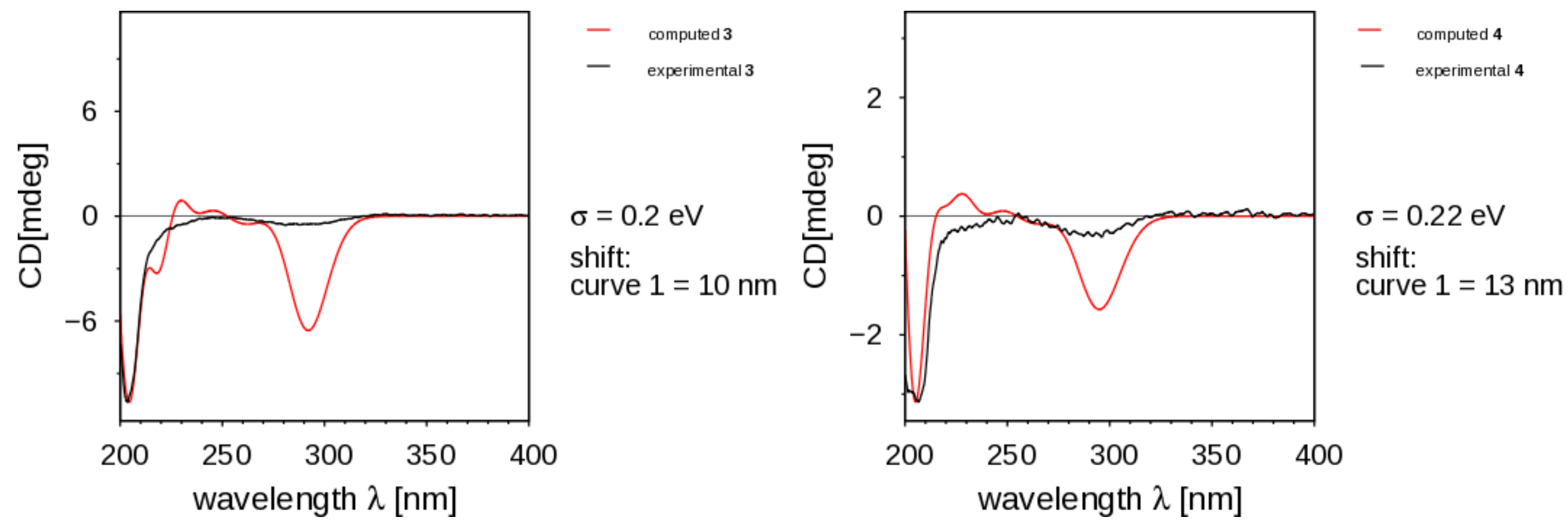

S46. Superposed experimental ECD spectrum (black) with the ECD computed spectrum (red) for compounds 3 (left) and 4 (right). 